\title{
Geochemical data for the Vasquez Peak Wilderness Study Area (A2361), the Williams Fork Further Planning Area (2-114), and the St. Louis Peak Roadless Area (F2361), Clear Creek, Grand, and Summit Counties, Colorado
}

By

H. N. Barton and R. L. Turner

Open-File Report 84-505

1984

This report is preliminary and has not been reviewed for conformity with U.S. Geological Survey editorial standards. Any use of trade names is for descriptive purposes only and does not imply endorsement by the USGS. 


\section{CONTENTS}

Page

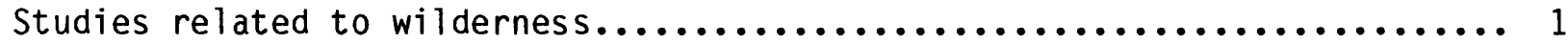

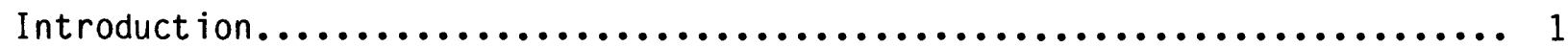

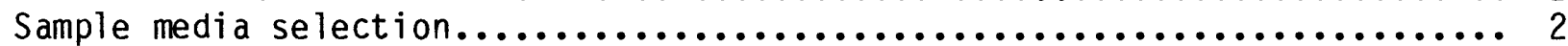

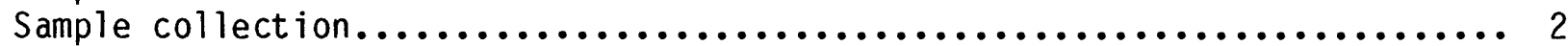

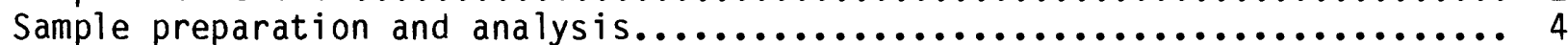

Rock Analys is Storage System (RASS) ........................... 5

References............................................... 5

\section{ILLUSTRATIONS}

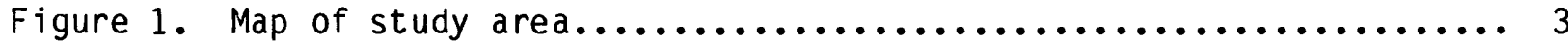

\section{TABLES}

Table 1. Lower limits of detection determined by emission spectrographic method...................... 6

Table 2. Spectrographic analys is of stream heavy-mineral concentrates from entire study area............................. 7

Table 3. Spectrographic analysis of ridgeline heavy-mineral concentrates from Keyser Basin.................................... 19

Table 4. Spectrographic analys is of ridgeline heavy-mineral concentrates

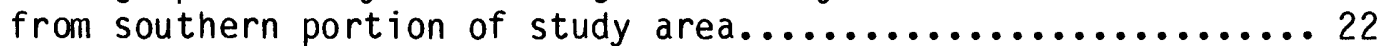

Table 5. Spectrographic analysis of ridgeline soil samples from

Keyser Basin................................... 40

Table 6. Spectrographic analysis of ridgeline soil samples from southern

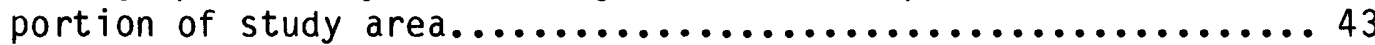

Table 7. Spectrographic analysis of ridge-flank heavy-mineral concentrates from southern portion of study area.................... 49

\section{PLATES}

Plate 1. Map showing location of stream bed concentrate sampling sites............................. In pocket

Plate 2. Map showing location of ridgeline concentrate, ridgeline soil, and stream bed concentrate sampling sites in the Keyser Basin............................... In pocket

Plate 3. Map showing location of ridgeline concentrate and ridge flank concentrate sampling sites in the southern portion of the

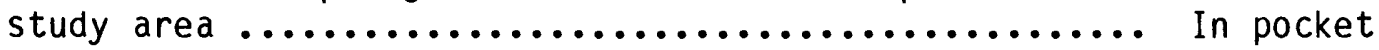




\section{STUDIES RELATED TO WILDERNESS}

The Wilderness Act (Public Law 88-577, September 3, 1964) and related acts require the U.S. Geological Survey and the U.S. Bureau of Mines to survey certain areas on Federal lands to determine their mineral resource potential. Results must be made available to the public and be submitted to the President and the Congress. This report presents the results of a geochemical survey of the Vasquez Peak Wilderness Study Area (A2361), the Williams Fork Further Planning Area (2-114), and the St. Louis Peak Further Planning Area (E2361), in the Arapaho National Forest, Clear Creek, Grand, and Summit Counties, Colorado. The Williams Fork and St Louis Peak roadless areas we re classified as further planning areas during the Second Roadless Area Review and Evaluation (RARE II) by the U.S. Forest Service, January 1979; the Vasquez Peak roadless area was established as a wilderness study area under Public Law 96-560, December, 1980.

\section{INTRODUCTION}

The U.S. Geological Survey and U.S. Bureau of Mines conducted field studies during the summers of 1979 through 1982 to evaluate the mineral resource potential of the Vasquez Peak Wilderness Study Area (16,000 acres) and the Williams Fork (74,820 acres) and St. Lou is Peak (12,800 acres) Roadless Areas. Included were geologic, geochemical, and geophysical studies by the U.S. Geological Survey and investigation of known mines and prospects by the Bureau of Mines.

The mineral resource potential of the area studied has been reported by Theobald and others (1983). Eppinger and others (1983) describe the geology as being Proterozoic metamorphic and igneous rocks with a narrow strip of Mesozoic sedimentary rocks on the west side of the Williams Fork Mountains. Early and Middle Tertiary dikes in the central and eastern parts and a complex system of Proterozoic to Cenozoic faults cut the rocks. Surficial cover is extensive, ranging from periglacially deformed, deep regolith on the gentle slopes of ridges, through glacial deposits on valley walls and floors, to alluvium in the lower valley bottoms.

This report describes the techniques used for collecting and analyzing the samples and presents the data from chemical analyses. Geochemical samples were collected during a regional survey and in more detailed follow-up studies of specific areas.

The location and approximate boundaries of the three contiguous areas are shown in Figure 1. The southeastern boundary of the Williams Fork Roadless Area from approximately the Eisenhower-Johnson tunnel to near Berthoud Pass is the Continental Divide. The corridor between the Williams Fork and St. Louis Peak Roadless Areas includes the Jones Pass road, the city of Denver's road/aqueduct at an elevation of 10,400 feet on the north side of Williams Fork, and the Forest Service road to South Fork campground at the junction of the South Fork and Williams Fork. The Vasquez Peak Wilderness Study Area and St. Louis Peak Roadless Area adjoin three sides of the Fraser Experimental Forest. 


\section{SAMPLE MEDIA SELECTION}

Many ore minerals are: (1) resistant to abrasion, (2) of high specific gravity, and (3) nonmagnetic. They may be separated from low-specific gravity minerals such as quartz, feldspar, and mica by field panning and laboratory specific gravity separation. In this heavy-mineral fraction, ore minerals may be separated from interfering and diluting iron and magnesium silicate minerals on the basis of magnetic susceptibility. Removed with the iron and magnesium silicate minerals are ore elements substituted in the silicate mineral lattice but the same element in an ore mineral is retained. The background for locating anomalous element concentrations related to ore mineralization is thereby lessened. Use of the nonmagnetic fraction of the heavy-mineral concentrate of the stream sediment results in more frequent detection of ore-related anomal ous element concentrations whose natural abundance in stream sediments is below analytical detection limits.

The sample media chosen for the initial regional study was the nonmagnetic fraction of a heavy-mineral concentrate from stream sediment. Each site provides a composite sample of the upstream drainage basin with contributions decreasing with distance upstream. One hundred sixty-four first-order stream sites provide nearly complete sampling of the 103,620 acre study area.

More detailed studies of areas found to be anomalous in the regional study were made by taking closely spaced (at 200-yard intervals) soil samples on the high, alpine ridges. Samples were also taken on ridge flanks above glacially deposited till. As with stream-transported sediments, specific gravity and magnetic susceptibility separations were made to reduce dilution and interference.

\section{SAMPLE COLLECTION}

Heavy-mineral-concentrate samples were collected at 164 streambed sites within an area of approximately $162 \mathrm{mi}^{2}$ ( 1 sample per $1 \mathrm{mi}^{2}$ average). Firstorder streams of 0.5 to $3 \mathrm{mi}$ length, draining basins up to $3 \mathrm{mi}^{2}$ area, were sampled. Enough material was passed through a 2-mm screen to fill a 16-inch-diameter gold pan to approximately 70-percent capacity. Panning was terminated when heavy minerals began to be lost or when the sample size was reduced to approximately $200 \mathrm{grams}$. Samples of heavy-mineral concentrate from stream sediment were collected from sites 1-129 in 1979; 1070, 1071, and 10821093 in 1980; 1137-1160 in 1981. Detection limits and results of analyses of the heavy-mineral concentrates from stream sediments are presented in Tables 1 and 2 , respectively. Plate 1 shows the map locations.

Soil samples from ridgetops were collected in 1980 on the Ptarmigan PeakBottle Peak-Byres Peak-Bills Peak-Peak 11605 ridge, which encircles the upper Keyser Creek basin (sites 1052-1060, 1072-1081, 1094-1101). Samples were taken at approximately 440-yard intervals. Every fourth sample was taken in sufficient quantity to be processed for a nonmagnetic heavy-mineral concentrate. Results of analyses of these unprocessed soils and heavy-mineral concentrates are presented in Tables 3 and 5, respectively. Map locations of both sample types, in addition to streambed sample sites in the Keyser basin, are shown in Plate 2 . 


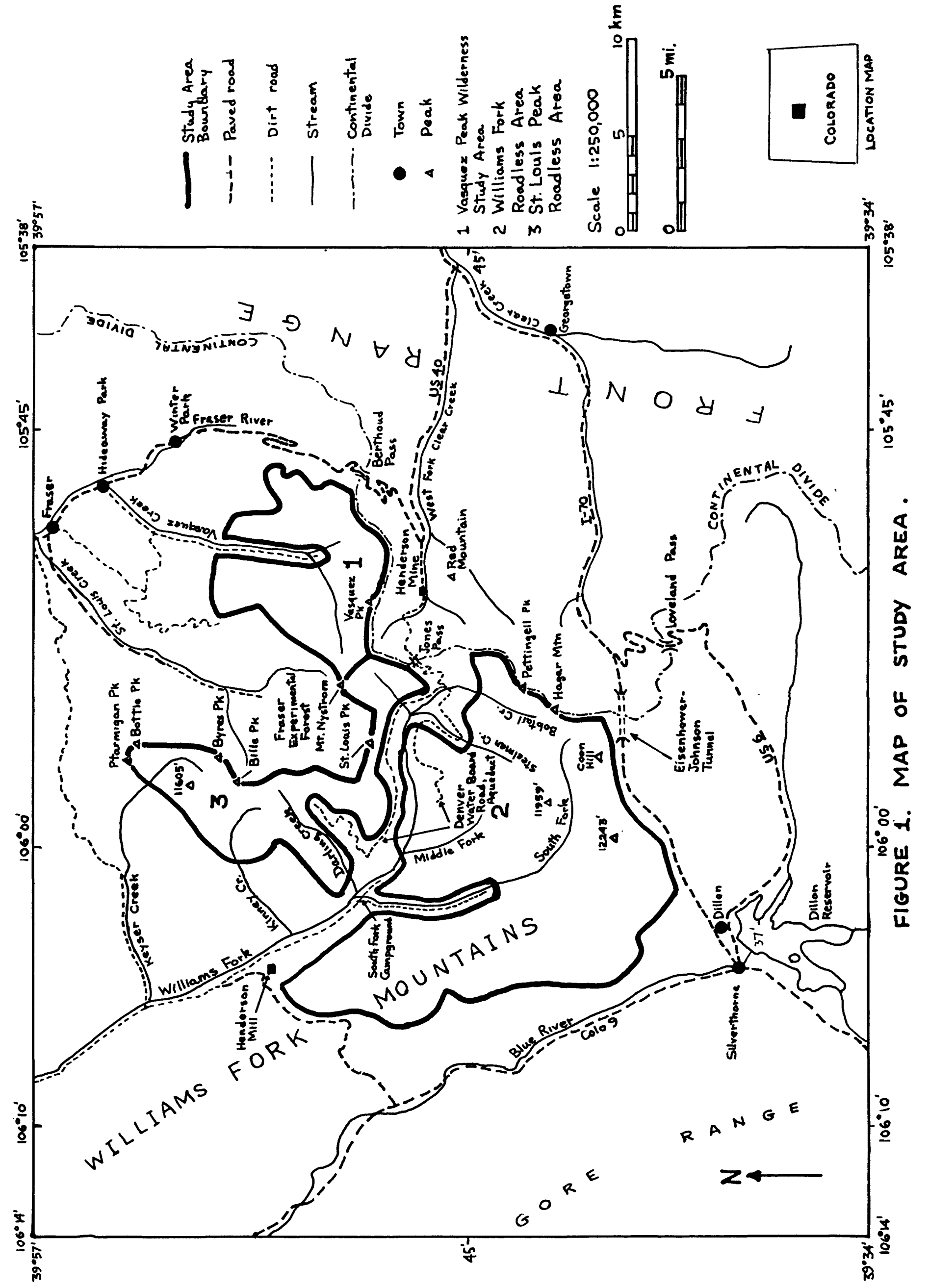


The southern portion of the Vasquez Peak Wilderness Study Area was sampled in the same manner during 1980. The area sampled included the Continental Divide from the Eisenhower-Johnson tunnel to Jones Pass, the ridge west from Hagar Mountain to Peak 11959, the east-west ridge through Coon Hill from Peak 12243 to the Continental Divide including minor ridges to the north and south, and the Bobtail-Steelman ridge (sites 1001-1051, 1104-1128). Results of analyses of the unprocessed soils and heavy-mineral concentrates from these sites are presented in Tables 4 and 6 , respectively.

In 1981, samples were collected on both flanks of selected ridges above the glacial till. Sites 1161-1171 and 1176-1185 were sampled along the Continental Divide in the vicinity of the Eisenhower-Johnson tunnel and 1186-1198 along the Bobtail-Steelman ridge. All samples were treated as heavy-mineral concentrates. Analytical data for these samples are presented in Table 7.

Ridgeline soil samples (sites 1199-1390 and 1450-1471), all large enough to be processed for heavy-mineral concentrates, were collected in 1982 . Sample intervals ranged from 500 to 650 feet. Ridges sampled at this close spacing for heavy-mineral concentrates were the same as those described above for 1980, excluding the Keyser basin, and including the north-south ridge west of Steelman Creek. Analytical data for these heavy-mineral concentrates, along with those samples collected in 1980, are presented in Table 4. Map locations for both ridgeline and ridge flank samples of heavy-mineral concentrates in the southern part of the Vasquez Peak Wilderness Study Area are shown in Plate 3 .

\section{SAMPLE PREPARATION AND ANALYSIS}

All samples collected from streambeds and ridge flanks and some samples collected on ridges were prepared as heavy-mineral concentrates. Those samples collected from streams were passed through a 2-mm sieve and panned at the sampling site. Two 1-quart cloth sample bags (5 $1 / 2$ in $\times 101 / 2$ in) containing approximately 7 bs of soil were filled at each ridge sample site. A heavy-mineral concentrate was obtained by drying, sieving at $2 \mathrm{~mm}$, and panning.

Panned concentrates were sieved to minus 30 mesh. Bromoform (specific gravity 2.80 to 2.89) was used to separate quartz, feldspar, clay, and other low-density minerals from the heavy minerals. The heavy-mineral concentrates were split into three fractions on the basis of magnetic susceptibility, using a Frantz Isodynamic Separator. The nonmagnetic fraction obtained at 0.6 ampere contained primarily low-iron magnesium silicates, barite, apatite, sphene, zircon, tourmaline, brookite, rutile, and most of the sulfide minerals and secondary minerals (alteration products) of base metals. This fraction was split; one part was used for mineral identification, and the other part was hand ground to provide a 5 -mg sample for emission spectrographic analysis for 31 elements by a six-step semiquantitative D.C. arc emission spectrographic method (Grimes and Marranzino, 1968). Heavy-mineral concentrates from ridge flanks were analyzed with different spectrographic parameters and have detection limits of one-half of those given in Table 1 . 
Ridgeline soils were sampled by collecting approximately $200 \mathrm{~g}$ of soil in a 0.15 -quart cloth bag ( $41 / 2$ in $\times 61 / 2$ in) at each site. Following drying and sieving to pass 30 mesh, samples were analyzed by the spectrographic method described above for panned concentrates. A 10-mg sample was used rather than $5 \mathrm{mg}$ and detection limits are one-half of those given in Table 1.

Analytical results, along with the latitude and longitude, are presented in Tables 2-7.

\section{ROCK ANALYSIS STORAGE SYSTEM}

Upon completion of all analytical work, the analytical results were entered into a computer-based file called Rock Analysis Storage System (RASS). This data base contains both descriptive geological information and analytical data. Any or all of this information may be retrieved and converted to a binary form (STATPAC) for computerized statistical analysis publication (VanTrump and Miesch, 1977).

\section{REFERENCES}

Eppinger, R. G., Theobald, P. K., and Carlson, R. R., 1983, Generalized geologic map of the Vasquez Peak Wilderness Study Area and the Williams Fork and St. Louis Peak Roadless Areas, Clear Creek, Grand, and Summit Counties, Colorado: U.S. Geological Survey Miscellaneous Field Studies Report 83 MF-1588B.

Grimes, D. J., and Marranzino, A. P., 1968, Direct-current arc and alternating-current spark emission spectrographic field methods for the semiquantitative analys is of geologic materials: U.S. Geological Survey Circular 591, 6 p.

Theobald, P.K., Bielski, A. M., Eppinger, R. G., Moss, C. K., Kreidler, T. J., and Barton, H. N., 1983, Mineral resource potential map of the Vasquez Peak Wilderness Study Area and the Williams Fork and St. Louis Peak Roadless Areas, Clear Creek, Grand, and Summit Counties, Colorado: U.S. Geological Survey Miscellaneous Field Studies Report 83 MF-1588A.

VanTrump, George, Jr., and Miesch, A. T., 1977, The U.S. Geological Survey RASS-STATPAC system for management and statistical reduction of geochemical data: Computer and Geosciences, v. 3, p. 475-488. 
Table 1.--Lower limits of detection for streambed and ridgeline, heavy-mineral concentrates determined by emission spectrographic method

[Detection limits for ridge flank heavy-mineral concentrate and ridgeline soil samples are one-half the values shown here.]

Element Detection

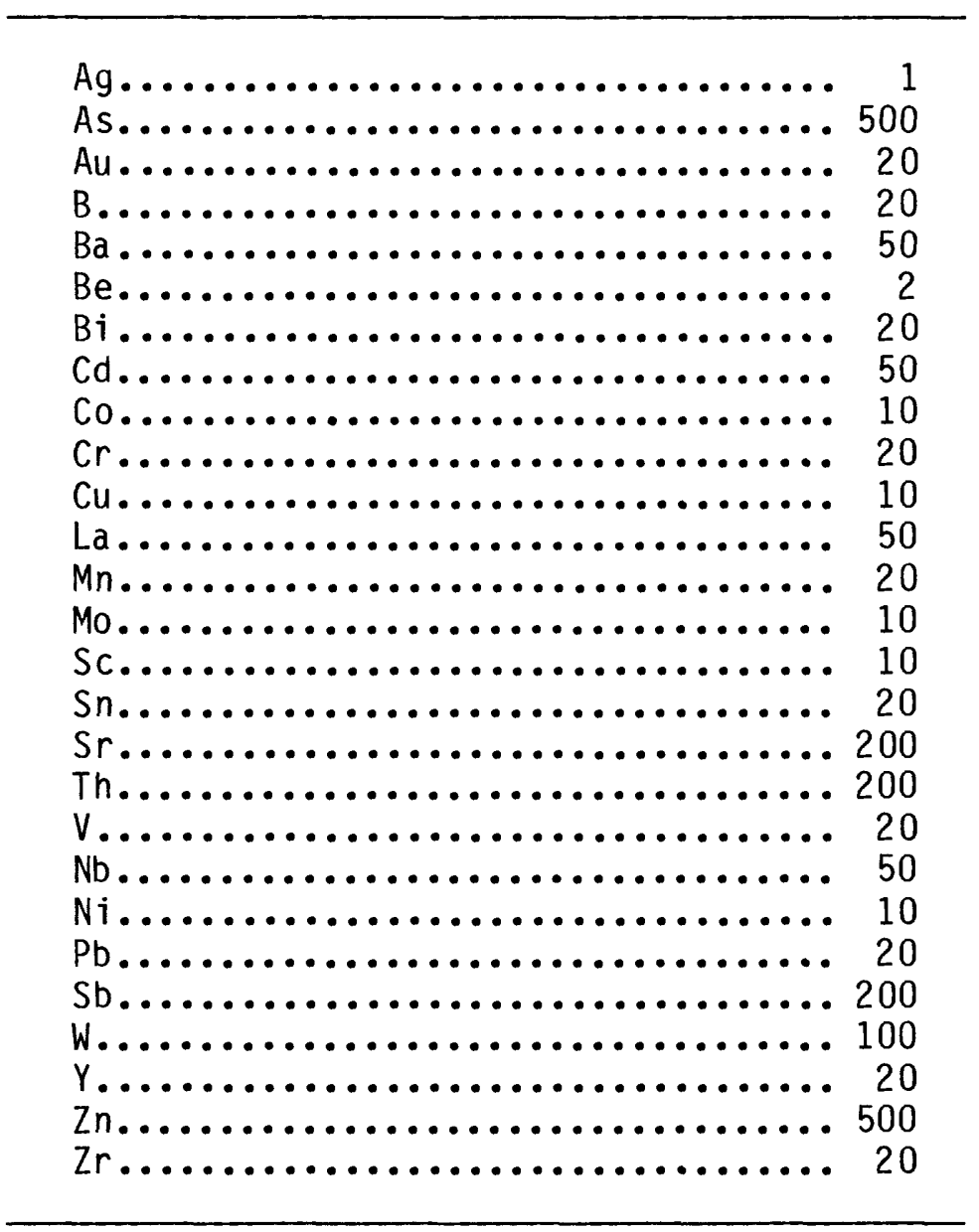




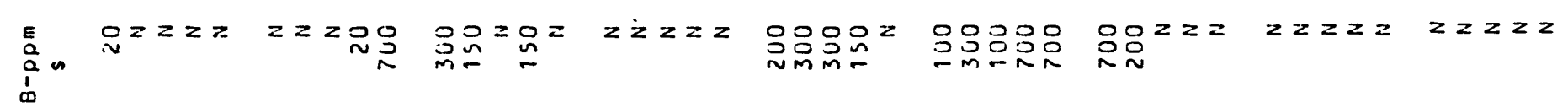

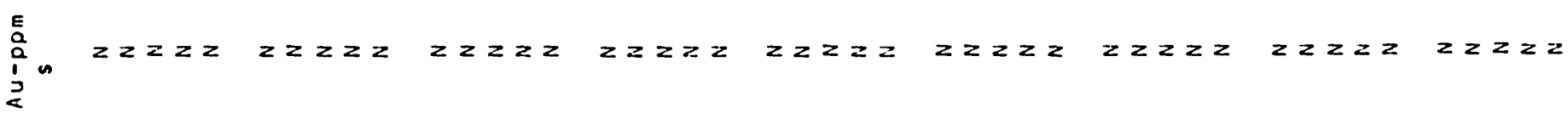

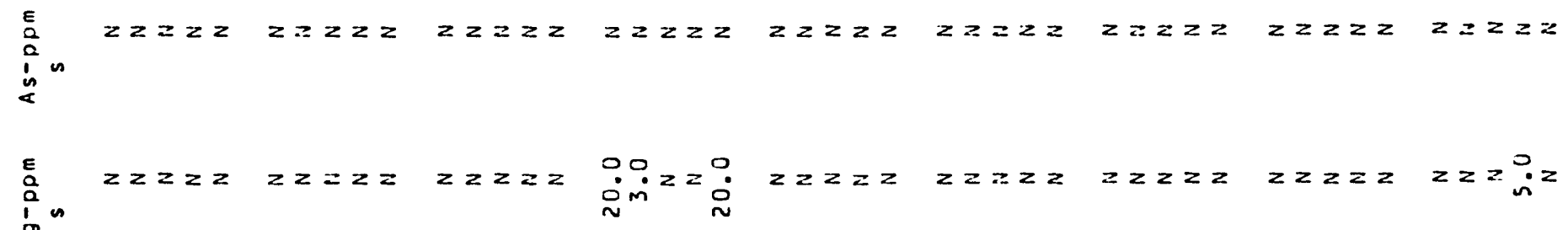

응ㅇㅇ응 잉욛ㄴ imin:

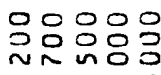

응영응응응 in

m눈

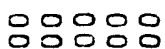

잉응응요

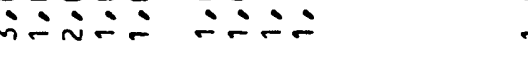

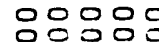
은용

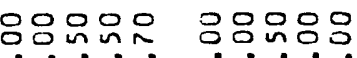
in்- $\therefore \dot{i} \dot{\sim}$

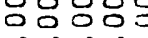
$\stackrel{\sim}{\sim} \sim \dot{\sim} \sim \dot{\sim}$ กำ 幺? แกํํำ 응옹응요 $\therefore \therefore \div$ $-\sigma-n$

00000

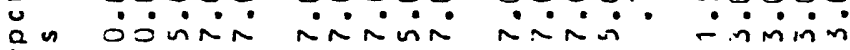
00000

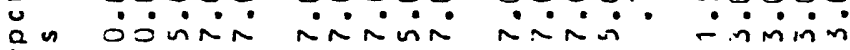

$0.00 \%$

n. $0.0 \%$ $\checkmark$

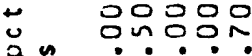
$\dot{\sim} \dot{\sim} \dot{-}$ E

$\therefore 0000$

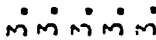

응응응응 응ㅇㅇㅇ응 $\dot{\sim} \dot{\sim} \dot{\sim}$ nmi.

은은은 in mm $m$

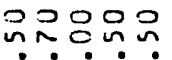

이잉

opo00 00000 in்幺i nisió

00000 ○ं í:

00000 0 n! n $n$

잉ㅇㅇ กำ?

ํำํำำ $\because$ กำ

$0 \operatorname{mon}$

00000

o000n minim जimm-

บำ ímas

on 000 m- imi

0 ? 0 ?
ma-min

000
minn-

00000 imimi

ำ?ㅇำ i

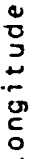

กับำง

o is $m \infty$

งัn

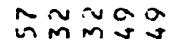

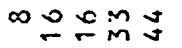

$\bar{\sim} \sim \sim$ in

$\sim \sim \sim \sim \sim$

N $-M m$

N $\sim-\infty$ in

ํํㅇㅇㅇㅇ

$\therefore 0000$

응이

जi in in in

nunmu

o0 000

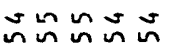

nn n⿺n

을응

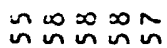

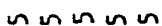

00000

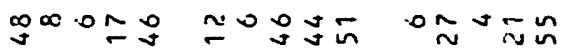

$\sim \sim \sim ⿻$ 而

nus $\infty$

그요의

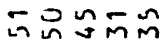

$m \propto \sim \sim m \bar{n}$

ํํำำ

ying a g

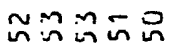

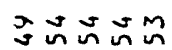

$\stackrel{\infty}{\sim} \sim \min$ in $m \cong g ?$

जिएव

初至合

måma

जिलिखे

ำริ

araag

Mimm

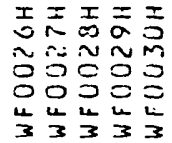

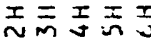

min mom

응응영

3
3

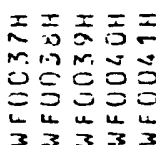

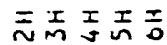
ปேㅎำ 이잉

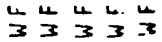


E $\begin{aligned} & \text { E } \\ & \text { 의 }\end{aligned}$

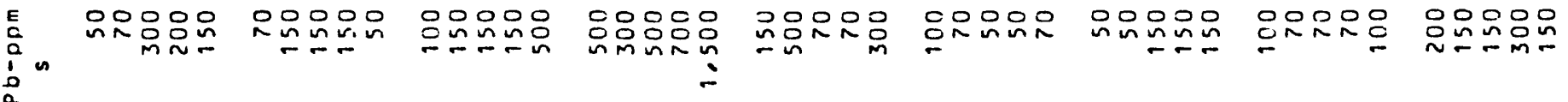

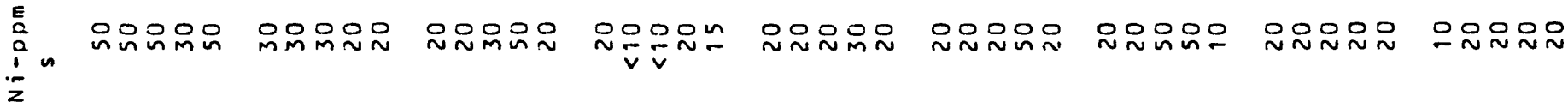

0000

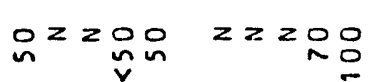
잉ㅇㅇㅇㅛ

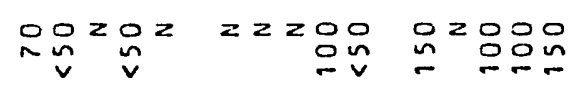
응ㅇㅇㅇㅇㅇㅇ

00000

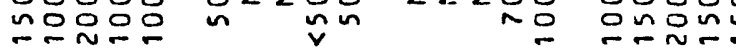
- $-v$

으는

e i.

Pnoon nugon opinmo

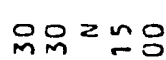
운웅ㅇㅇㅇ은

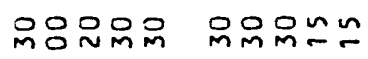
$n m i n n$

응ㅇㅇ으는

E 궁ㅇㅇㅇㅇㅇ

nnio응

$\therefore \therefore i n$

옹ㅇㅇㅇㅇㅇㅇㅇㅇ

임소는

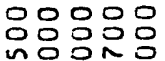

요

엉ㅇㅇㅇㅇㅇㅇㅇㅇㅇ

in?

0
090
090
0

응응ㅇㅇㅇㅇ 음응ㅇㅇㅇㅇㅇㅇㅇ

응ㅇㅇㅇㅇㅇㅇㅇㅇㅇ
응요

응응ㅇㅇㅇㅇㅇㅇ

응ㅇㅇㅇ $\tilde{\sim} \dot{\sim} \dot{\sim} \dot{n}$

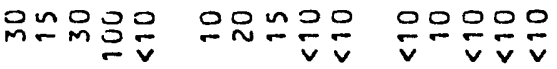

요용ㅇㅇ

은은은

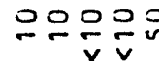

$\because$ 응은

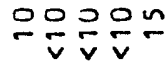

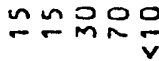

$E$
2
0
$\vdots$
$\vdots$

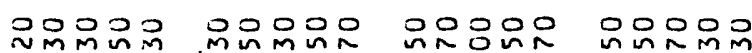

은융ㅇㅇ

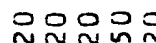

은윤유

은요요요

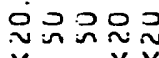
s

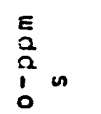

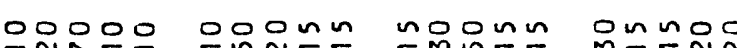

의의요요

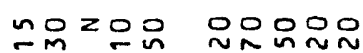

은으으응

융요 은요 웅

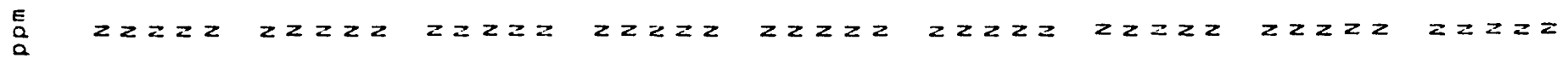
in

$2 z=2$

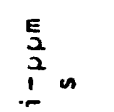

$z \geq z \geq$

$z z=9$
$\vdots$
$\vdots$

$z z z z z \quad z z z z$

$z z z z$

$z z z z z \quad z z z z$

$z z z z z$

$z=2 z z$

음으 monN

\section{응옹옹ㅁㅇ}

곡옹ㅇㅁㅇㅇㅇㅇㅇㅇ

은

응응응ㅇㅇㅇㅇ $\therefore$ 눈

영응응용

옹옹ㅇㅇㅇ은

응응ㅇㅇㅇ 응음

$\therefore$

응음옹ㅇㅇㅇ

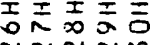

III工杰资 등옹웅응웅 0000

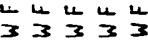

II工政西

응응응무

언언인인이

$\begin{array}{lll}4 & 4 & 4 \\ 3 & 3 & 4\end{array}$
王至无王 등드응응 이응으 4
33 333

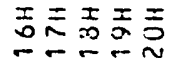
드응응 $\begin{array}{lll}4 & 4 \\ 3 & 3 & 3 \\ 3 & 3\end{array}$
I志杰王

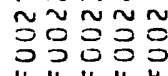
$\begin{array}{llll}4 & 4 & 4 & 4 \\ 3 & 3 & 3\end{array}$
กำก

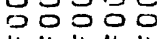

$\begin{array}{lll}4 & 4 \\ 3 & 3 & 3\end{array}$
王吉志吉吉

ตmตn

잉잉잉

$\begin{array}{lll}4 & 4 \\ 3 & 3 & 4 \\ 3 & 3\end{array}$

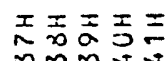

ำm

잉음응ㅇㅇㅇㅇㅇ

$\begin{array}{lll}4 & 4 \\ 3 & 3 & 3 \\ 3\end{array}$
元王王司 งัง 옹응음ㅇㅁㅇ $\begin{array}{lll}4 & 4 \\ 3 & 3 & 3 \\ 3 & 4\end{array}$ 


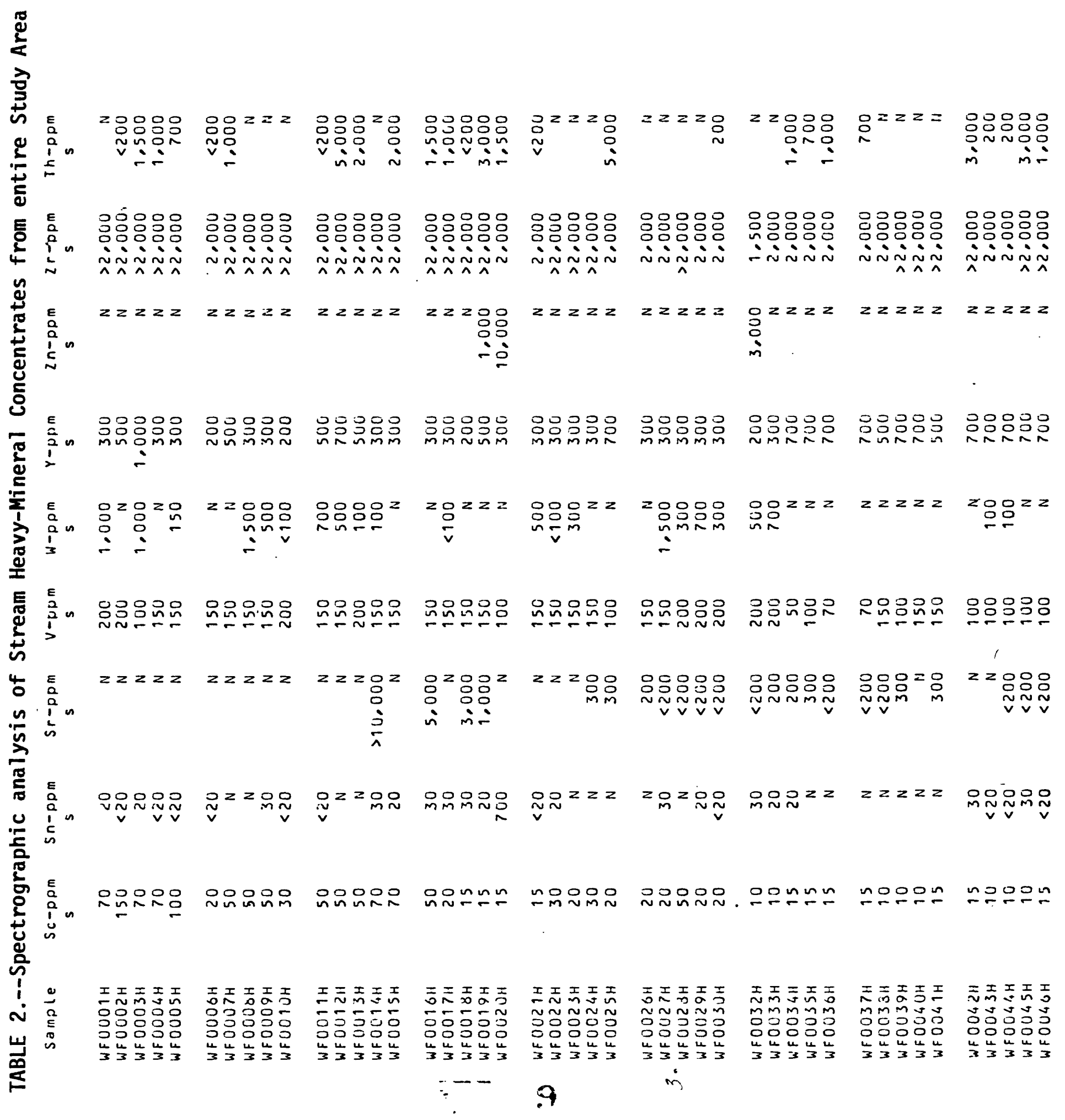


$z=z z z \quad z z z z z \quad z z 0 z z \quad z \geq z z z \quad z z z z 0$

E

$z=2$

$2 z<2$

$20=2$

$z \geq z \geq z$

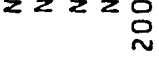

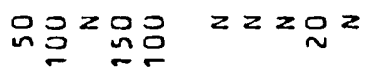

은은 은응

영 $z \geq 2$ ㄴ

ญับ

곤

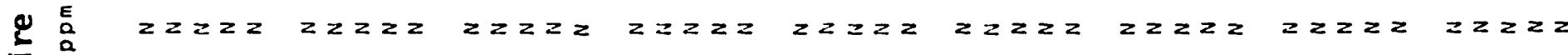

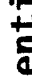

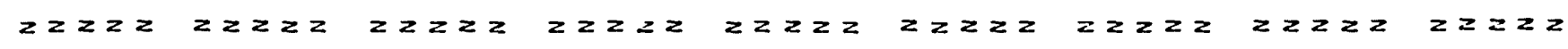

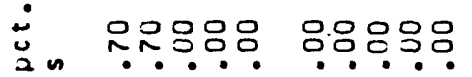

- $\underset{\sim}{\sim}$ in $\dot{\sim} \sim \underset{\wedge}{\sim} \dot{n}$

음웅유은

웃응응요

inis:-

$\because \because \because$

옹유윰응

옹응응음

ĩi்i

융우운음

앙ㅇㅁㅁㅇ

$\because \therefore \sim$

^

$\therefore \sim$

$\because \because \frac{1}{20}$

영음음요

- 00000

in்jo

00000

0.030

on 0 ?

웅ำ

ingo?

00000

뜬웅

00000

ヘ

0.000 .0

rorir noga

궁

-

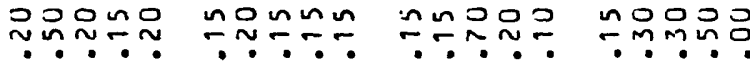

an ?.?.

on

$\sim 2$

$\frac{\pi}{2}$

$\therefore$ nonnm

กำ

$0 \backsim \sim 00$

00000

$\because ? \because \div \div$

$=0000$

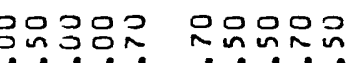
$\ddot{-} \dot{\sim}$

m-nm $\sim \sim \sim \sim \sim$ imi -
0.0.?
응으요은

$\therefore m-$.
응옹ㅇㅇ음 ำ แ $-1$
응은은 ……
00000 mimmin o 00 mo

$\dot{n} \div \div$
ㅇำ? min -

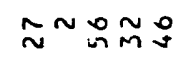

ज识

ㅇำ $\infty \sim \sim$

$\sim \infty \sim ⿻ 上$

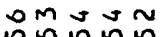

nnmun

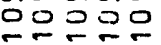

응ㅇㅇㅇㅇ은

in $\frac{1}{0}$ in

Im n

ง $\{$ แ

๓ำกำ

กับ

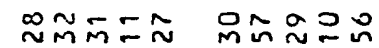

wa $a=0$

$>\infty \div \infty 0$

ama

$m \sim n \infty$

แกษนก

in 0

nn

○ீல்

은으으은

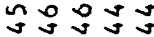

araa

워웡워

बiन

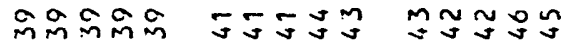

mangin araac

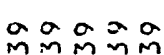

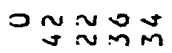
OOOR

응으음 $\approx a v m a$ a a a 0

mnnmo

은은은 gin ingo

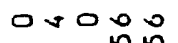

웅음ํำ

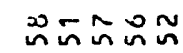
$m i n n \infty$ ำ

\section{志现吉项纴 고의 응응ㅇㅇㅇㅇㅇ 出出出出 \\ II I I I 证的绳 응릉ㅇㅇㅇ uㄴ.4

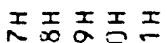

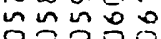 엉ㅇㅇㅇㅇㅇ 는는}

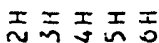

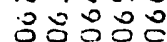
이잉

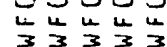

조이 0. Oㄷㅇㅇㅇㅇ 는
玄元无无紊 กิกลก 응응응 는는는

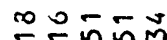
a 0 o a
워의 $=$ 象品的识识

araa ตำำำ

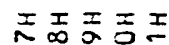
승요 응응응응 ㄴ. 는
杰忈杰贡

$\infty \infty \approx \infty \infty$ o 000 ○อง 00 $3 \frac{4}{3} \frac{4}{3}$
I I I I I $\infty \infty_{\infty}^{\infty}$ 잉ㅇㅁㅇㅁㅇ 군군은 $3 \frac{4}{3} \frac{4}{3}$ 


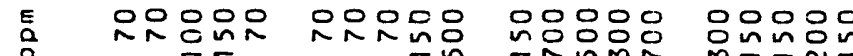

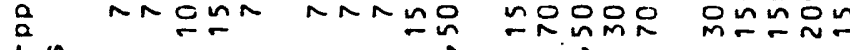

bo

$\div$

$\div$

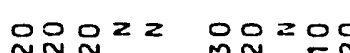

온웅ㅇㅇ 운은은

옹ㅇㅇㅇㅇㅇ음

응응ㅇㅇ음

응응응으오 인

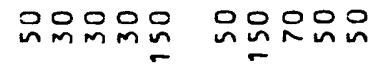

$\frac{2}{2}$

\begin{tabular}{ll}
2 & $E$ \\
\hline & 0 \\
\hline & 1 \\
0 & 1
\end{tabular}

NNN mn $-n$

กNก

N N N

은옹ㅇ

은요은

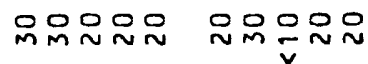

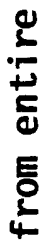

E 02000

02000 o0000

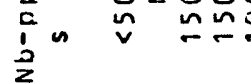

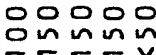

00000

00000

00000

00000

$z 2 z 20$

20200

$\underset{v}{\sim} 20 \underset{v}{0} \underset{v}{v} z$

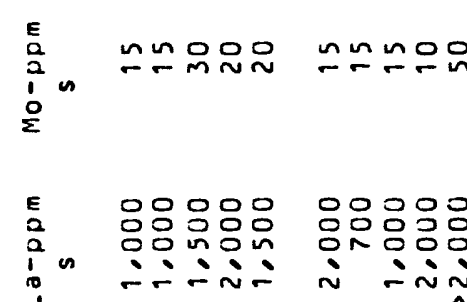

$2 z 00 z$

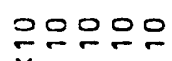

no요은

$\frac{1}{2} \frac{2}{2}=$

유는ํํํำ

웅ㅇㅇㅇㅛ

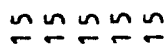

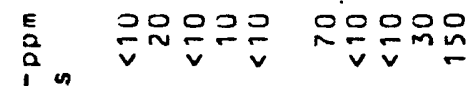

은은유소

옴응응응영

岏㐫

豆品品品品

음응응음

응응융음

$\therefore \dot{\sim} \dot{n}$

in $\dot{\sim}=\dot{n}$

응ㅇㅇㅇㅇㅇㅇㅇㅇㅇ

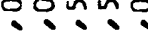

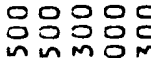

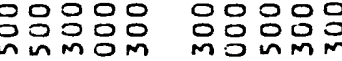

ヘ

$\therefore$ :

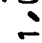

in $\mathrm{m}$

00000

근은응은

엉ㅇㅇㅇ은

은ำ는

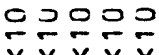

응ㅇㅇㅇㅇ은

30

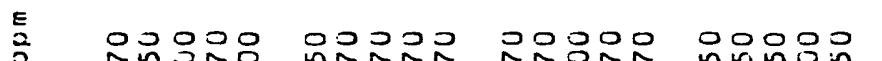

온응ㅇㅇㅇㅇㅇ

Uñ⿻上丨

hos

in $\operatorname{nos} 2$

은곤ㅇํㅇ응

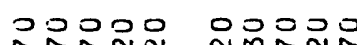

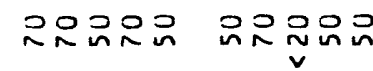

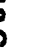

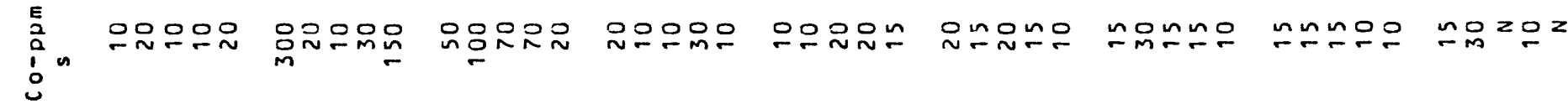

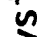

${ }^{E} \quad z=z z=$

$\sum \sum_{0}^{1} n$

$z z z z z \quad z=2 z$

$z=22 z \quad 2: 2 z=$

$z z z z$

$z z z z$

$z 2 z z 2$

$z 2 z z z \quad z 2 z 2 z$

응

$E$
$\vdots$
2
1
1

$z 2 z z z \quad z z z z$

$2 z 2 z$

$z z 2 z 2$

$z 2 z 2 z$

$z 2 z z 2$

22222

$2 z 2 z$

$z 22 z 2$

인 $n N$

กำ

$\ln z z 2$

$2 \geq 00$

nOOOOO

늠으

$\sim$

Oํㅗㄴ

$2 z n n n$

$n \geq z \geq n$

zozn

i

을 음 음음윤은

음음응ㅇㅁ옹

员品吕品品

웄욱음

응

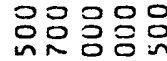

: 원

응응ํํ음

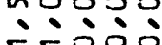

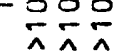

エェ去齐吉至

งัง

익잉ㅇㅁㅇㅇㅇㅇ

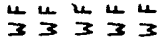

Lิํํㅇํำ

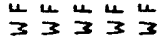

II五五工

00000

$4 \frac{4}{3} \frac{4}{3} \frac{4}{3}$ นn

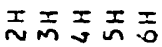

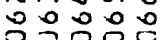
03000

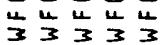

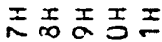
ㅇํㅇำ 잉응ㅇㅇㅇ

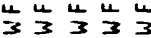

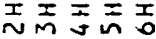

กิ̃ก̃์

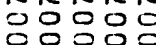

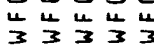

응엉영응 m:

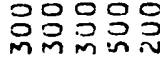
-

옹옥ㅇㅇㅇㅇㅇㅇ ำ $\mathrm{M}$ 슨

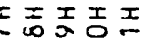
승ํㅇㅇㅇㅇ 음ㅇㅇㅇㅇㅇ 芆枈落莎

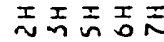
c) 0000 0050 3433

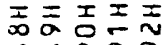

x心o.a 잉영응

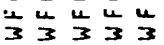




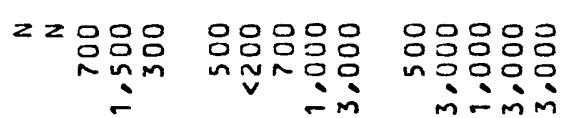

过是的

怤

E نññ

응응응음

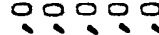
$\sim \sim \sim \sim \sim$

응응응응

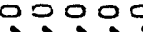
$\sim \sim \sim \sim \pi$ N $\sim \sim \sim n$

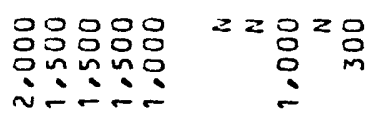

응응ㅇㅁ

웅응용ㅇㅁㅇ

iniñ

응응음영

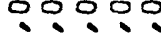

$\dot{\sim} i \dot{i n}$

응응ㅇㅇㅇㅇㅁ

무유유 $\sim \sim \sim \sim \sim$

응응영음 iñin

응응음움

$\sim \sim n \sim-$

음응응응은

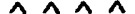

$2222 z$

2222

$z 2 z 20$

$z 2 z 0$
$\vdots$
$\vdots$

o0

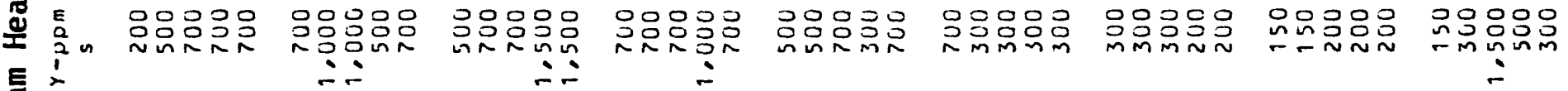

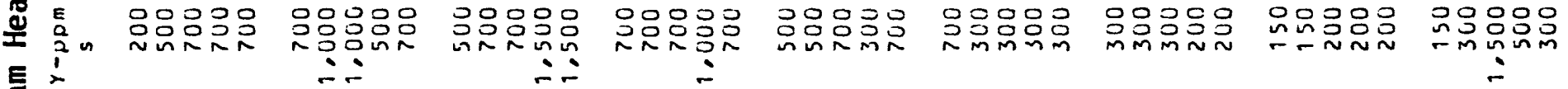

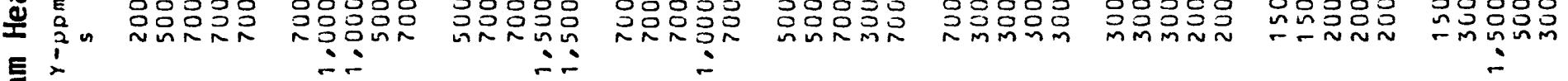

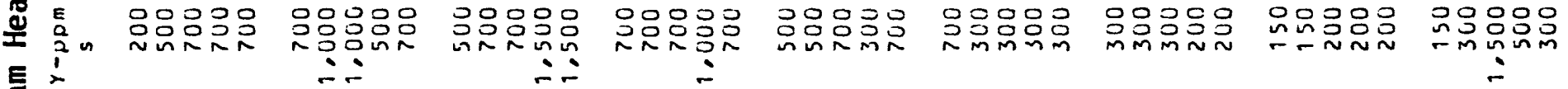

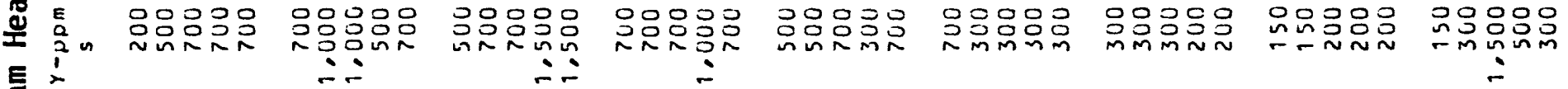

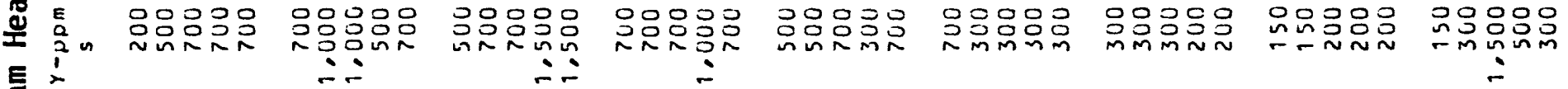

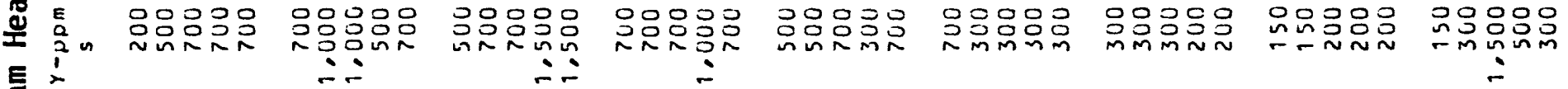

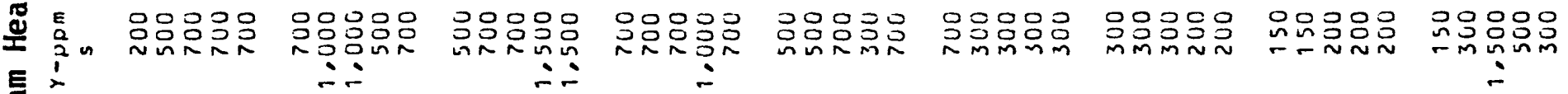

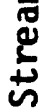

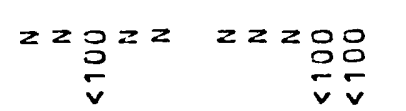

$z=00$

응으

2220

$z z \geq z$

$z=2$ 응음

응 $=2$ 응은

z 22 응음

22202

$\frac{n}{2}$

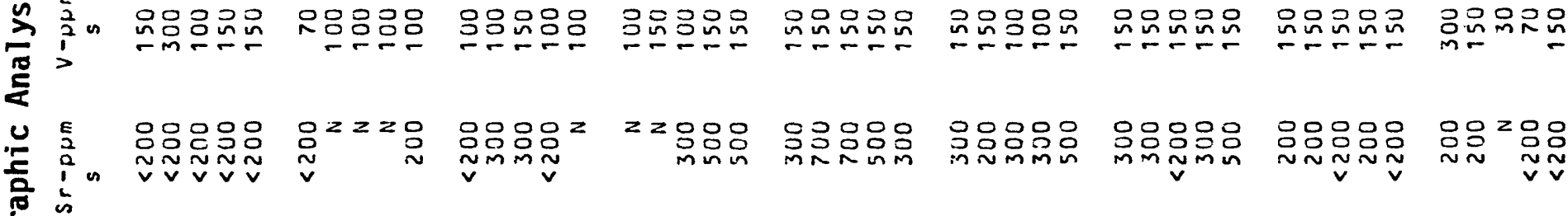

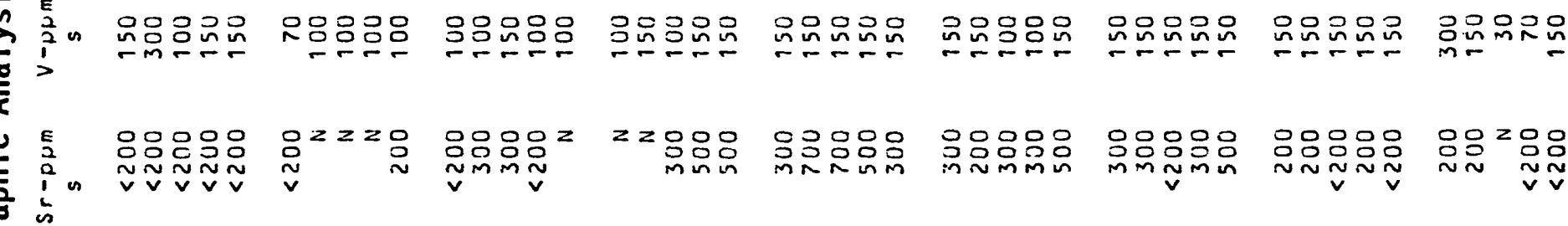

के

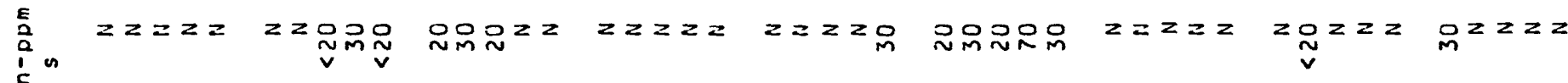

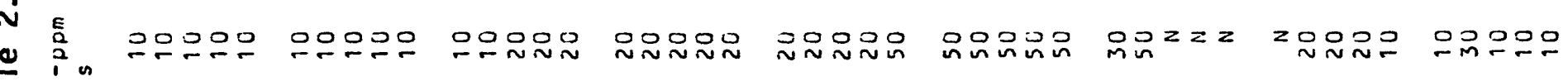

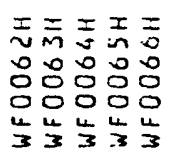

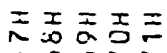

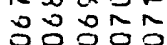
응응응음 $\frac{4}{3} \frac{4}{3} \frac{4}{3} \frac{4}{3} \frac{4}{3}$

离示采 กิธ่วิธิ์ 음잉응

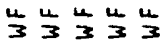

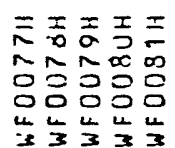

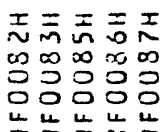

포초듬

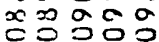
등그음

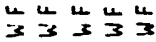

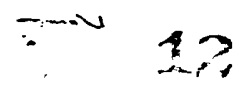




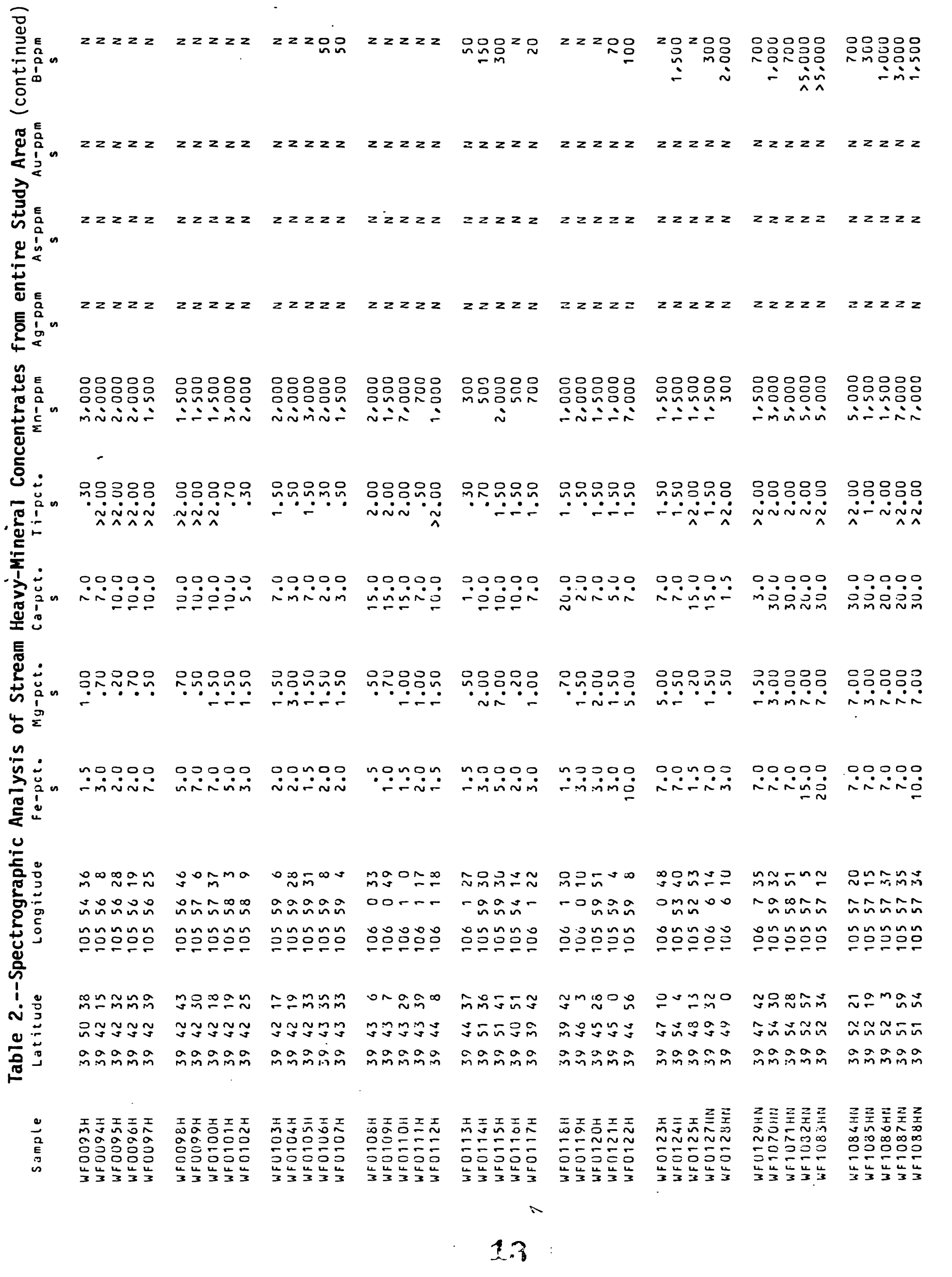




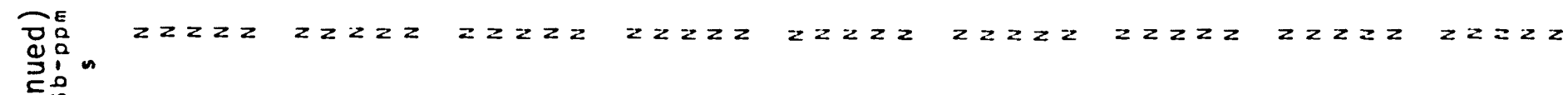

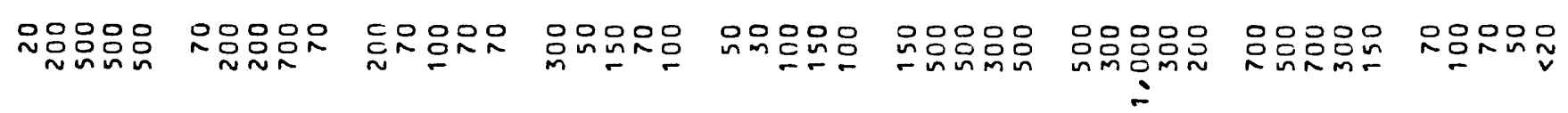

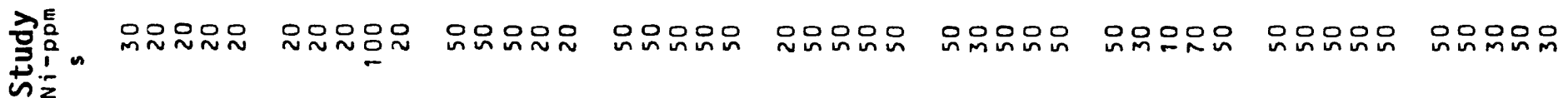

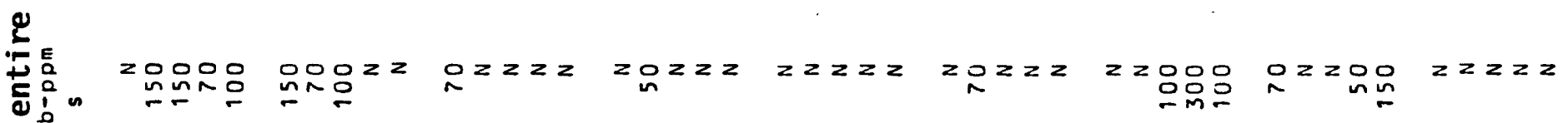

틍

恶

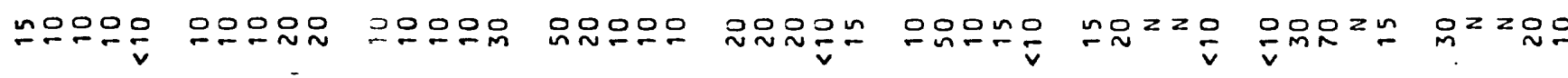

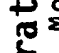

$+$

EE

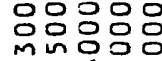

응ㅇㅇㅇㅇㅇㅇㅇ

응응응

$\therefore$ in

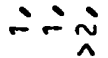

응ㅇㅇㅇㅇㅇ 응응으음

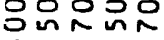

"َ.

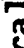

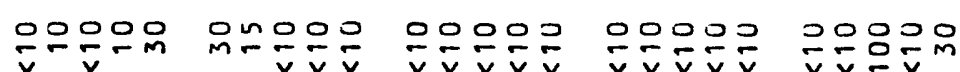

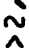

¿

응응ㅇㅇㅇ

응ㅇㅇㅇㅇㅇㅇ

옹ㅇㅇㅇㅇㅇㅇㅇㅇ

in

iñ

잉ㅇㅇㅇㅇㅇㅇㅇ 응은응응응 iñ

응ㅇㅇㅇㅇㅇㅇ 음앤ㅁㅅ 옷인

$\wedge$

$\therefore$ N:

음응ㅇㅁ운

으은은은

유으는곤

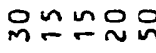

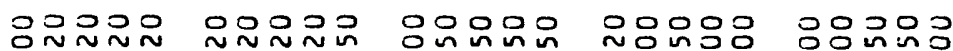

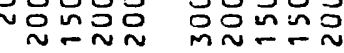

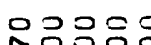

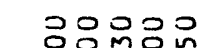

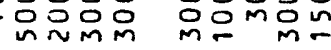

응ㅇㅇㅇㅇㅇㅇㅇ

공ำ 它

里

㝳

4 !

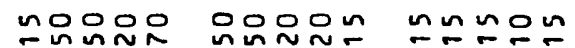

$z=0$ no

$20 \operatorname{in} 0$ i

으른요요요

운은은은

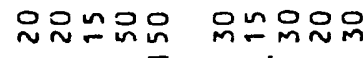

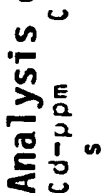

$z \geq z \geq z$

$z z z z$

$z z z z z$

22222

22222

$z z z z z \quad z 2 z z z$

$2 z 2 z 2$

$z z 2 z z$

年高

$z z z z 2 \quad z z 2 z z$

$z 2 z 2 z$

$z \dot{z} z z$

$z z z z$

$z 2 z=2$

$z z z z$

$22 z 2$

$z z z z$

$\sim z z z$

$z z z \stackrel{\sim}{n}$

$\stackrel{0}{\sim}$

$\because$ 엄요

옹요 $=0$

으늠

$n z z z z$

$z \geq z z 2$

$z z z z 2$

i

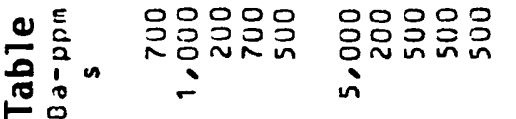

음옷옥음옹

옥응익응은 in

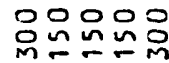

옹ㅇㅁㅇㅇㅇㅇㅇㅇ

옹읏ㅇㅇㅇㅇㅇㅇ 읏
읏

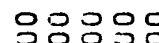

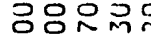
두

을응응ㅇㅇㅇㅇํ

도돋

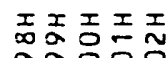
잉두웅

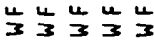

I 응ㅇㅇㅇㅁㅇㅇ응 55505

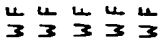

范㕕项志 음둔 05050

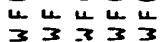

永吉贡现

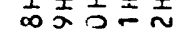

$=E=E=--N \sim N$

05050

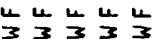

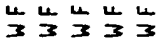

는는

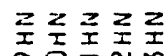

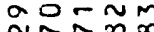
등잉ㅇㅇ

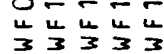

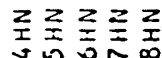

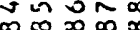
我品? $-=-\div=$ 录出录录 


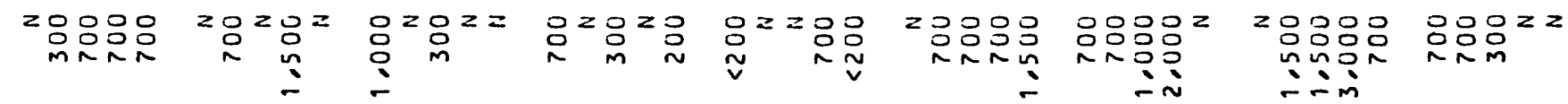

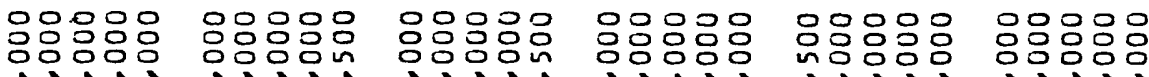

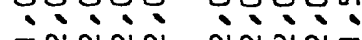

ini

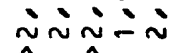

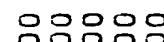

$\wedge \wedge \wedge \wedge$

$\sim \sim \sim \sim-$

$\sim \sim \sim \sim \wedge$

$-\tilde{\sim} \tilde{\sim} \tilde{\wedge}$

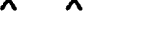

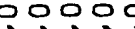

iñ⿻上丨

웅ㅇㅇㅇㅇㅇㅇㅇㅇㅇ

응ㅇㅁ문

응영응음

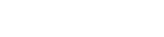

$z z z z$

$z z z z z \quad z z z z$

$z z z z$

$z<z=$

$z z \geq z 0$

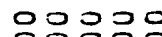
은은은은

党

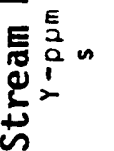

잉ㅇ 00000

识品

음음ㅇㅁㅇㅁㅁ

웅웅옹ㅇㅇㅇ

등은옹요였

은음옹음

웅응ㅇㅁㅇ

잉요

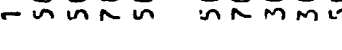

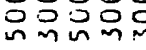

옹음음

엉잉옹ㅇㅇㅇ $\therefore$

$4 \frac{E}{2}$

$z z z z$

$z \geq z 0$

$20{ }^{0} \geq z$

$z \geq z z$

$z \geq 0$

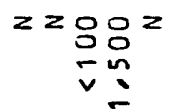

으의 $z z z$

20200

옹ㅇㅇㅇㅇㅛ

告

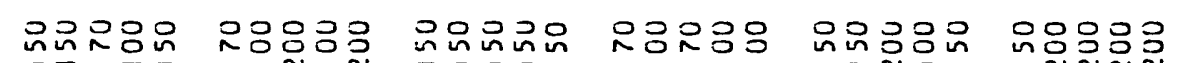

.

r.
응ㅇㅇ응

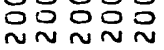

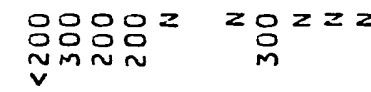
总品品品品
2을웅유
음 $\underset{\substack{0 \\ \sim}}{\sim} \underset{\sim}{\sim}$
음을 옷용

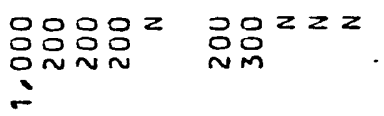

로유유

윰요 $z z z z z z$

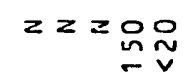

$z z z z z=z z z z$

$z<\underset{\sim}{\sim} \underset{\sim}{\sim}$

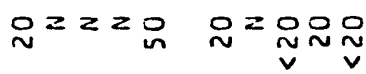

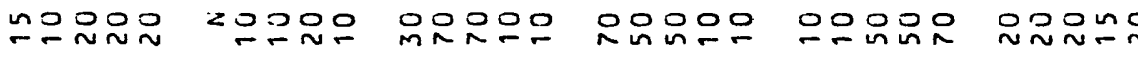

은유요

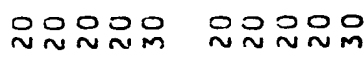

足

(2)

(n)

nก⿻
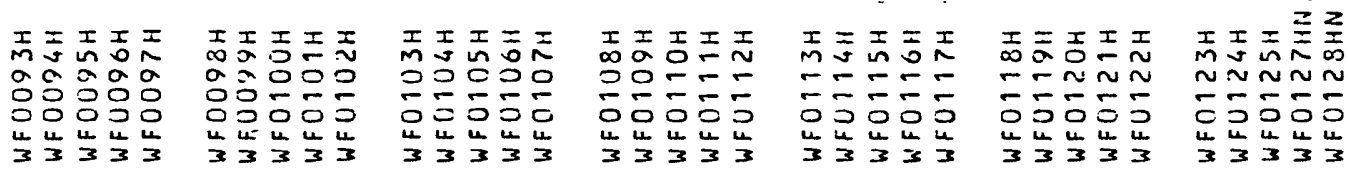

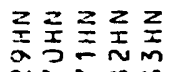

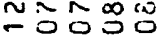

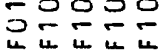

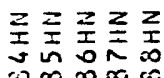

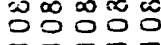
느는 3333333333 


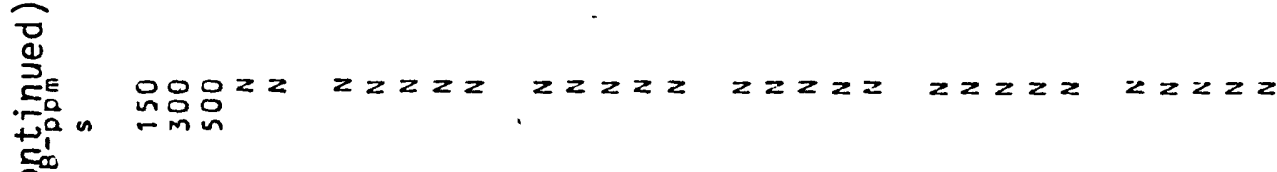

范

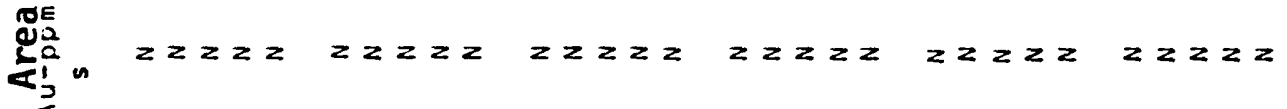

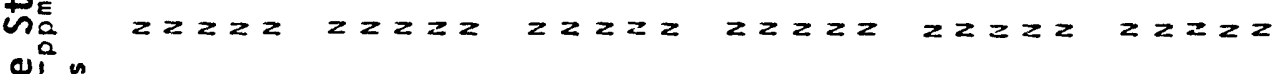

赵

E: $\quad z \geq z$

$z z z z$

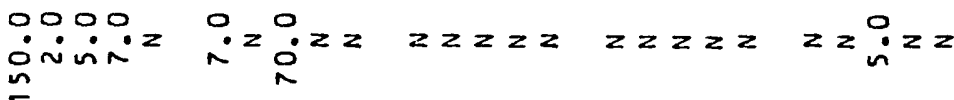

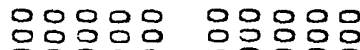
기잉

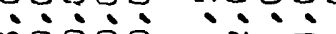
응응ㅇㅇㅇㅇㅇㅇ
응응응응
옹ㅇㅇㅇㅇㅁ

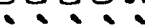
on on

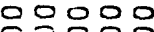

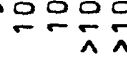
inis:

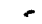

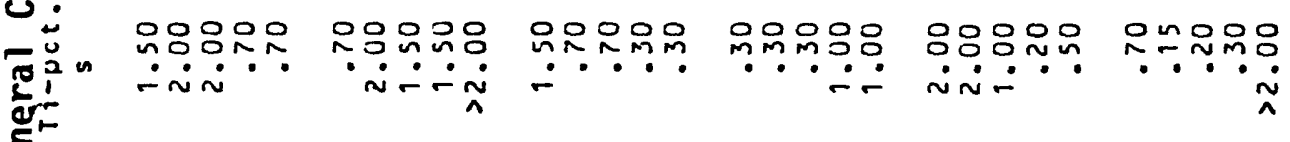

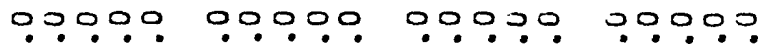

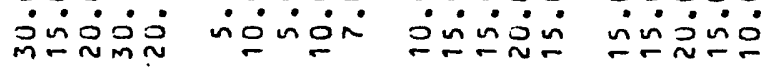

00000

00000

$\sum u$

是:

mand

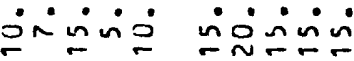

E

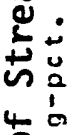

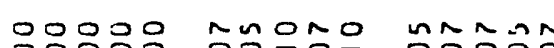

in 100 in

ำ.?

0.000

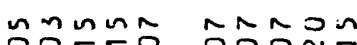

วกก no ininion

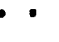

$0 \Sigma$

00000

inisin

ำ? ำ

$\because n n \operatorname{mn}$

nm $\because ?$

n m n ? ?

$\because \because n \backsim 0$

है:

툴

\section{ano $0 \mathrm{~m}$}

$\sim_{0} 0 \sim \underset{\sim}{n}$

ํำ

- Mำ

ติกำกับ

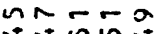

gag 0 in

ñ n $\min \infty$

에요요

jog

m $n$ nn $n$

$\ln \min n$

nunnm

num n m

$\operatorname{sog} \sin$

응으으응으

은은응

은으응

으르으으으

응응

누음ํ요

gagas

num nn

응ํํ응ํํ

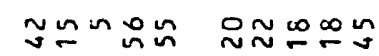

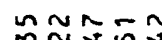

踏的

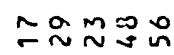

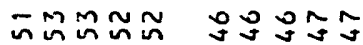

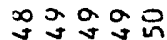

in $\sim ⿻ 上 丨$

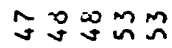

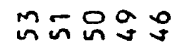

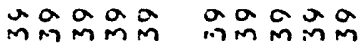

a a a

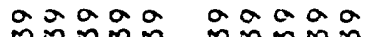

åa

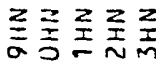

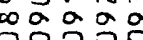

금으응

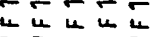

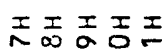

MmMSE

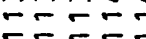

$\frac{4}{3} \frac{4}{3} \frac{4}{3}$

I $\frac{x}{m} \bar{x}$

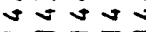

$\div= \pm=5$

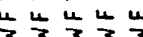

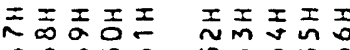

ำ는

- - -

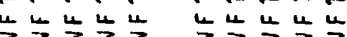

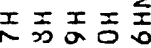

nn n⿺m

든

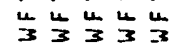




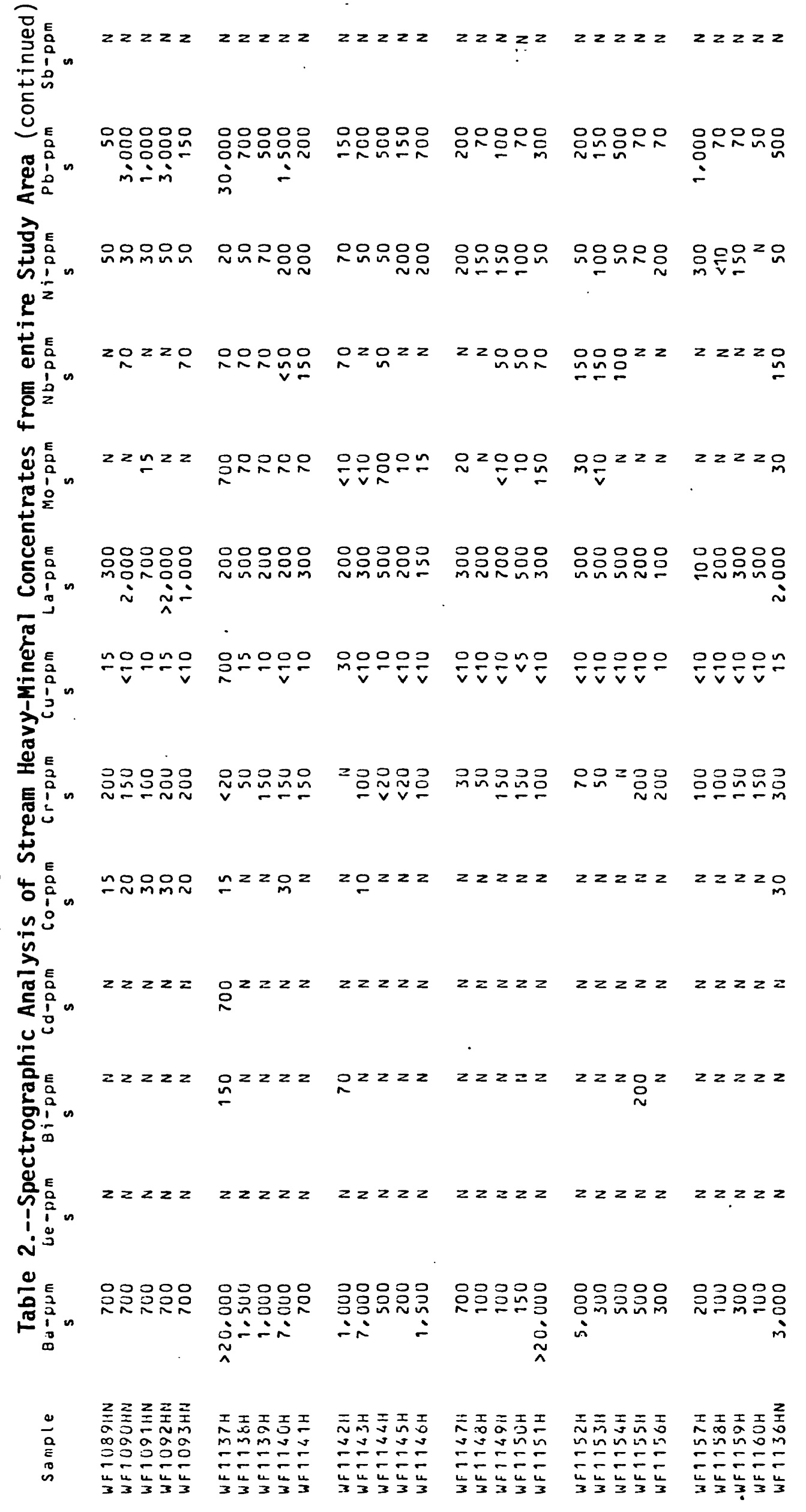




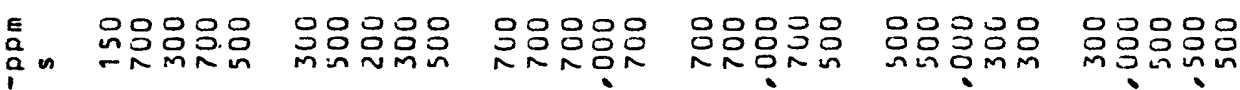
E $\therefore \div$

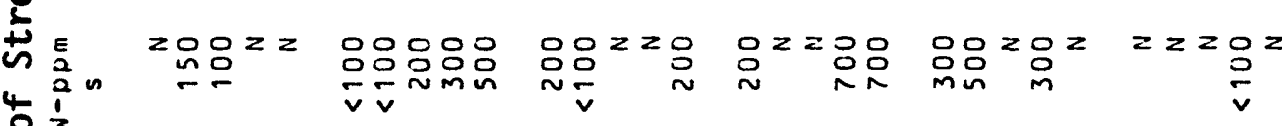
$4 \div$ 的告

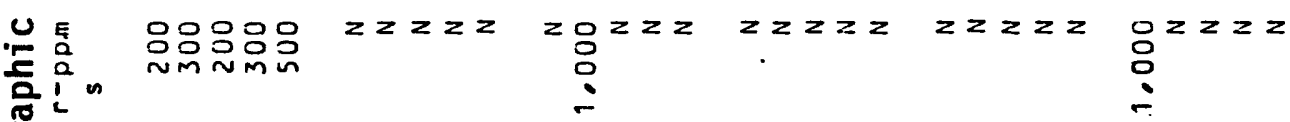
2

용 بै山

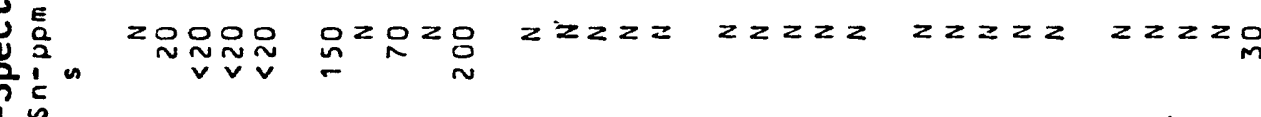
i. N E⿱ อ 음

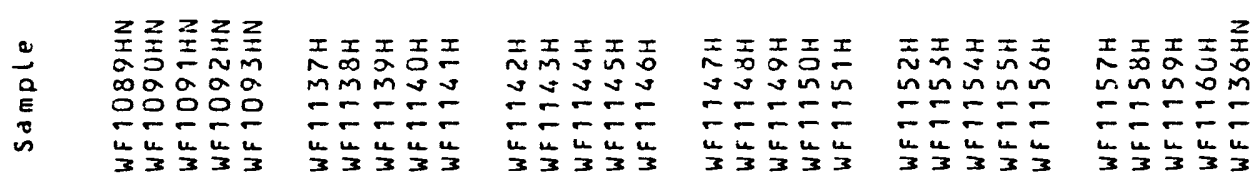

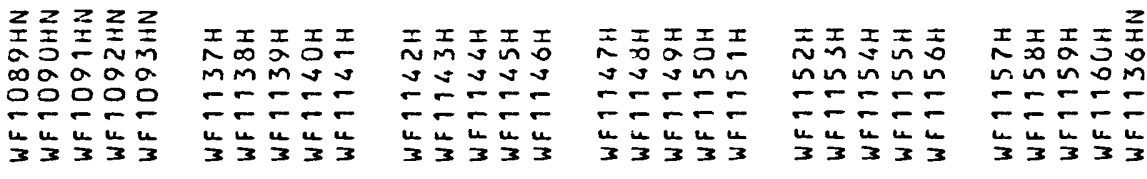

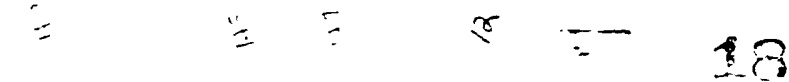




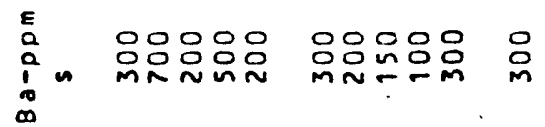

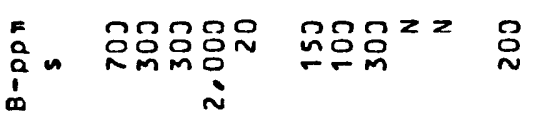

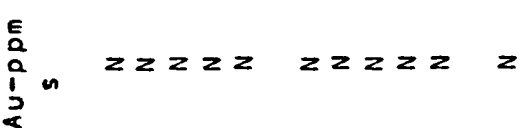

总 $z z z z z \quad z z z z z \quad z$

En

造产员 $2 z z z z \quad z z z z z \quad z$

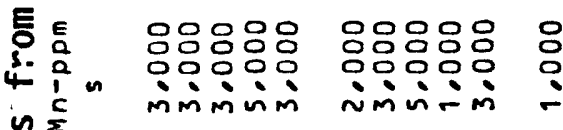

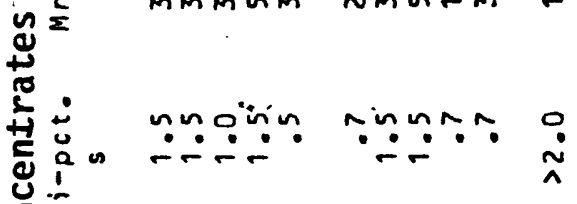

둥

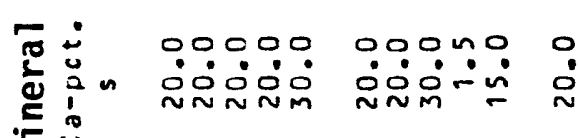

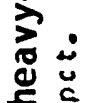

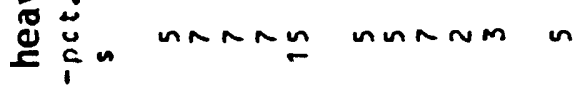
o con

兵

察 :

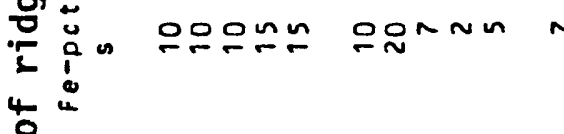

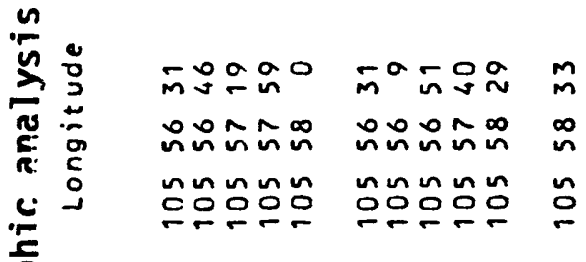

क⿻

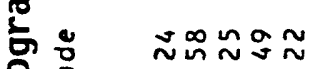

$\simeq \sim \sim \infty D$

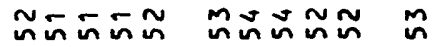

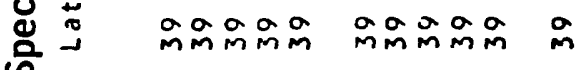

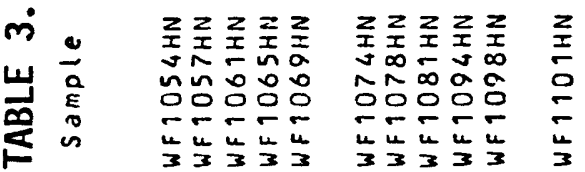


E⿱

है $\quad z z z z z z z z z$

$i^{1} n$

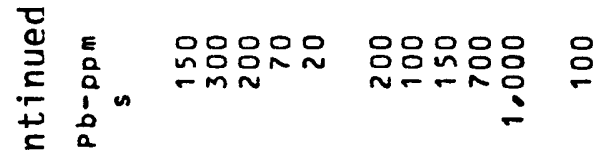

I

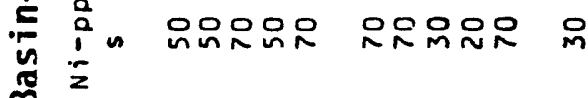

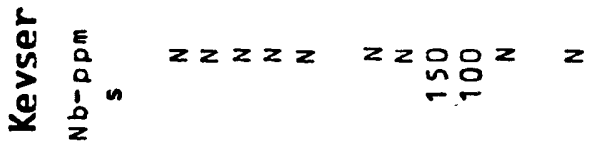

통

y:

is

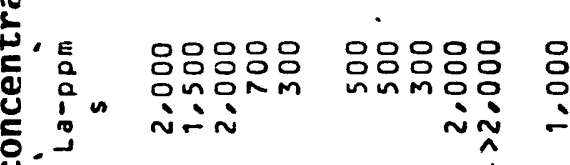

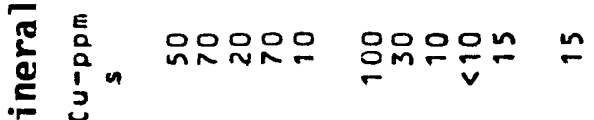

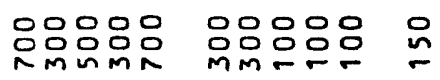

E in RMnmN MmFFr

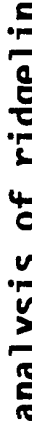

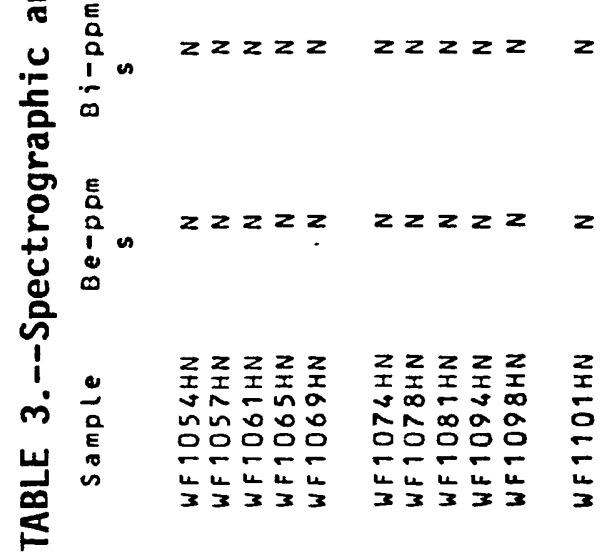




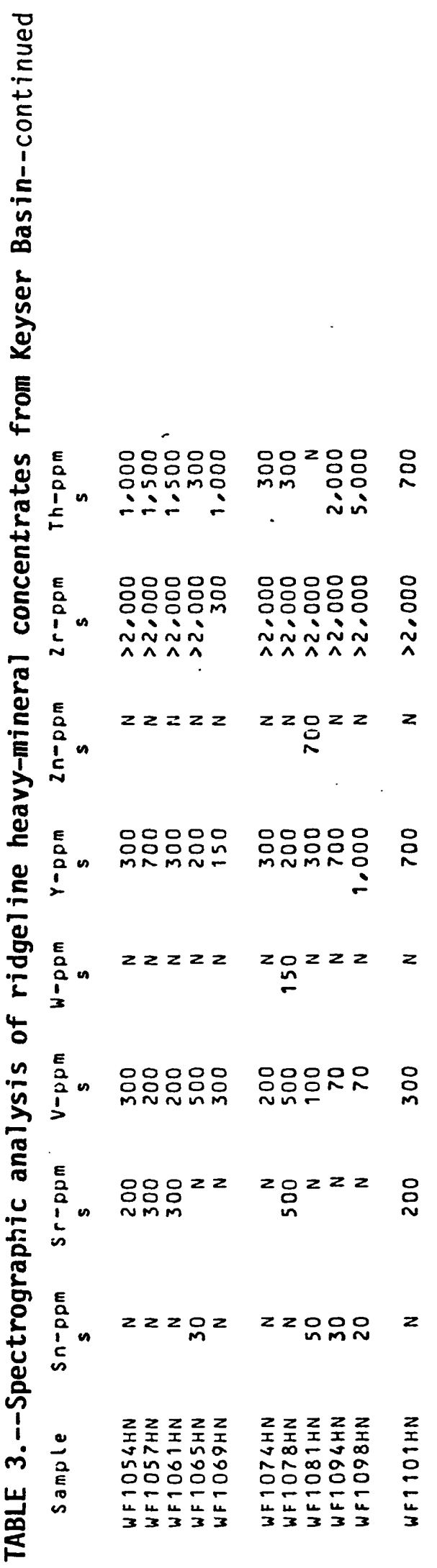




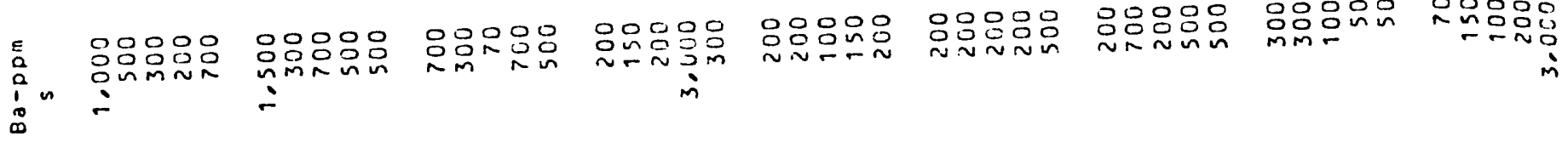

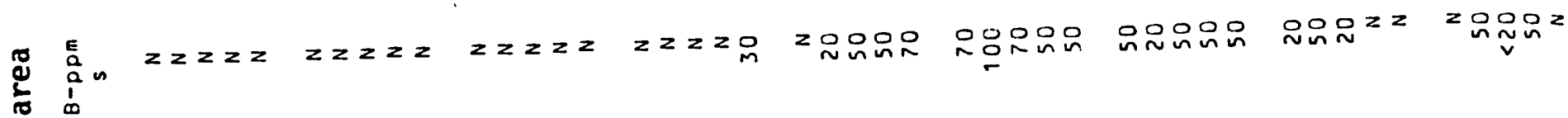
冚 $4 \int^{1}$

$<$

政

हु

E 응ㅇㅇㅇㅇㅇㅁ

픈

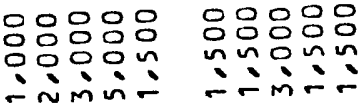

음웅음

$\frac{c}{2}$

4 ㅇoㅇㅇㅇㅇ

$\dot{\sim} \dot{\sim} \dot{\sim} \dot{n}$

응응ㅇㅇ음

$\dot{\sim} \dot{\sim} \tilde{\sim} \sim$

응응응으.

iñ்

$\approx \pi \approx N \pi$

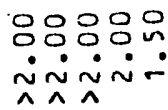

$\because 0900$

ก0:0웅 호요

iñnim

00000

ríni

0.0 .90

무뭄

00000

ำing-

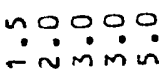

00000

응용요 inin-

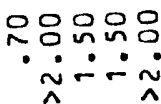

옹용ㅇㅇㅇ

$\dot{\sim} \dot{\sim} \dot{\sim} \dot{\sim}$

$\wedge \wedge \wedge \wedge$

ininivi

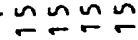

00000

vi̊jó

응응응음

iñن்

$\wedge \wedge \wedge$

응응응음

iñin $\wedge \wedge \wedge \wedge \wedge$

oogno i̊ํ요

00000

웅ㅇㅁ웅

00000

00000

ognon

oonino

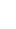

이응

onoon

nnกํㅇㅇㅡ ทmทั丶万

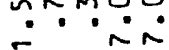
บำ? …? ำ

… ำก … 年

00000 웃ํㅇ

ํํii

00000

00000 niminin 9000

o on 00 ᄂ :

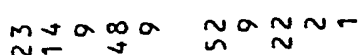

nunuon

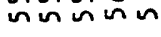

* nunun * 은으은

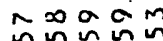

nnnun

ํㅡㅇํำำ응

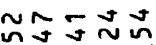

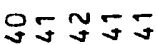

$0 \infty \pm \sim \infty$

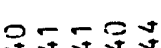

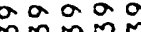

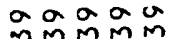

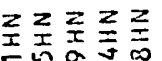

응으응

比比立

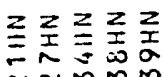

กับำ

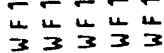

ีㅡㅇㅇํ요

$\sim \sim m \sim n$

แนทนกน

응ㅇㅁ으음

-

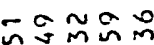

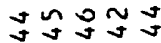

in i $^{\circ} \mathrm{m}$

롯로ㄹㅗㅗ롱

mก̃

엉ํㅇำ

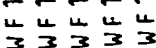

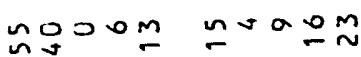

งnona

แกทักทั

กนกnน

으몽ㅇㅇㅇㅁ른

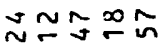

ษึษษ

a aua

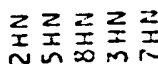

$\sim-\sigma \sim \sim$

ニニニニ

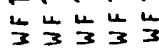
itet
至无王无

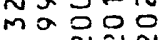
$=2 \pi$ 드는

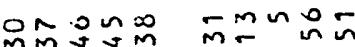

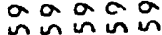
un unin 으응ㅇㅇㅇㅇㅁ

tasn a 2 in 웅여워 asinga

a a a a 33333

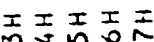

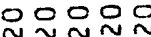
든 比能
动无无王元 윰ㅊㄲ rar

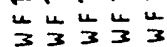

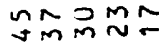
$\infty \infty \infty \infty \infty$ ถทก่ทn

แกแนก 으옹ㅇㅇㅁㅇㅇ

mma テテ55 a a a a

另示项 $\bar{\sim} \bar{n} \bar{n} \bar{N}$ N-1 岲药落 テテ5テ5 arara o으을

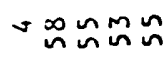
船药药药 แกแน⿰幺幺 므응으음

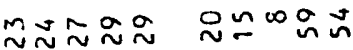

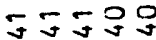

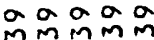

I工工玨王 $-\approx N \approx$ $\sim \sim \sim \sim N$ 는든 
웃유운음

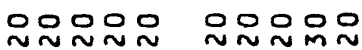

$2 \geq 0 \geq 0$

Ozzzz zzzz

$z 2 z 2 z$

$z z z z z \quad z z z z z$

$z z z z$

$z z z z z \quad z z z z$

$z z z z$

$z z z z$

$z z z z$

$z z z z 0$

함

in

(a)

4- E

응ํำำ

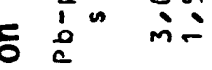

$\stackrel{2}{\frac{1}{2}}$

$e^{2}$

a

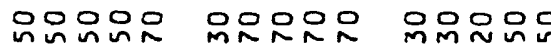

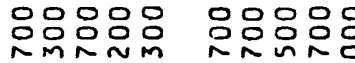

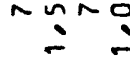

음용음

min

oo 000

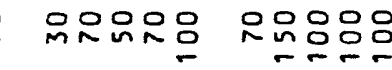

z

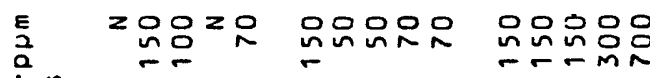

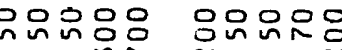

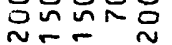

응오응은은

2 은응요

응엉유숫

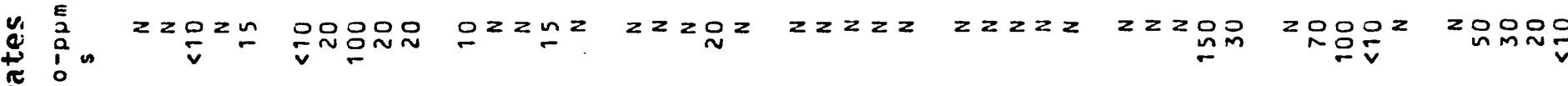

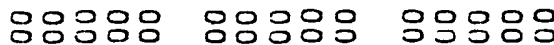

응음음욤

inin

응응ㅇㅇㅇㅇㅇㅇ

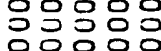

잉ㅇㅇㅇ

iñin

$\sim \sim \sim \sim n$

음음음

no의

$\because \dot{\sim} \sim \dot{n}$

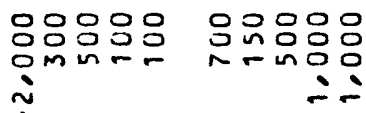

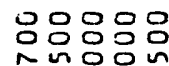

r.

$\therefore$ in:

3

E

옹요융

m융요

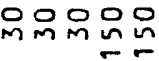

응윰요용

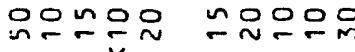

은으늠 3

$\frac{E}{2}$

\&

\section{응ㅇㅇㅇㅛ}

0000

o0000

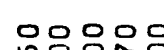

\section{잉ㅇㅇ}

응응음웅ㅇ

o는

n

n은ㅁㄴ

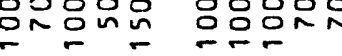

은음은요

잉

$\underbrace{}_{0}$

E

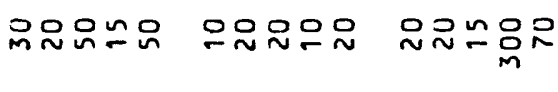

응융유은

일 zzzzzzz

$z z z z 2$

$4-$ 0

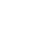

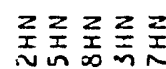

ำฺก

듬

는

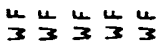

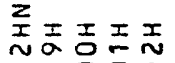

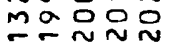

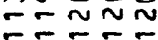

峛范范

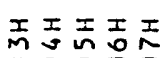
응ㅇㅇㅇㅣ $\sim \sim \sim \sim N$

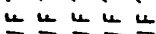
3333

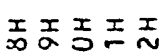
余云六 - -2

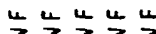

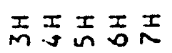
$\bar{n} \bar{n} \bar{n} \bar{n}$ $\simeq \simeq \simeq N \cong$ 든 范落落落
西至吉元 $\tilde{\sim} \tilde{\sim} \sim \tilde{N}$ NNNN 든든 


\section{틍 응응음은}

in 무욤

응음음운

옹응응응

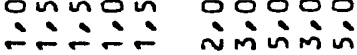

옥응옴은

웅

inis:

$E$
$\vdots$
$\vdots$
$\vdots$

응응응음

응응ㅇㅁㅇㅇㅇㅇ

$\dot{\sim} \dot{\sim} \dot{\sim} \dot{n}$

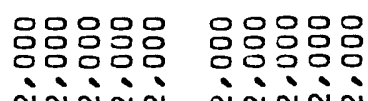

응응응음음

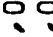

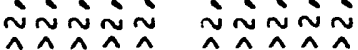

$\sim \sim \sim \sim \sim ⿻$

웅응ㅇㅇㅇ용

․․․․․

$\sim \sim \sim \sim \sim ⿻$

응응응응음

$\dot{\sim} \dot{\sim} \dot{\sim} \dot{x}$

옹응응응

oㅇoㅇㅇㅛ

iñin

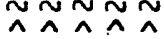

$\sim \wedge N \wedge N$

응음응응

음ㅇㅁㅇㅇㅁ

iñi்

옹응응음

章

a $\quad z z z z$

$22222 \quad 2222 z$

$22 z 2 z$

$z z z z z \quad z z z z z$

$2 z 2 z=$

$\wedge \wedge \wedge \wedge$

$\sim \wedge \sim \wedge N$

E 00000 00000 00000

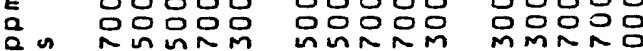

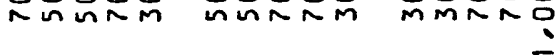

00000

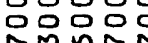

응ㅇㅇㅇㅇㅇㅇㅇㅇ

응ㅇㅇㅇㅇㅇ잉

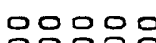

음ㅇㅇㅇㅇㅇㅇ

$\because ?$

잉ㅇㅇ잉

응ㅇㅇㅇㅇㅇㅇㅇ 응응응응음 2

$z z z z$

$z z z z$

$z \geq z$ in

$z z z z z$

$z z z z z \quad z z z z z$

0
0

z응음ㅇㅁㅇ 음음음은

톡 은은응음

응응응ㅇ

응응앵ㅇㅇㅇㅇㅇㅇ융ㅇㅇㅇㅇㅇ

은은융ㅇㅁ 응옹은윤

잉ㅇㅇㅇㅇㅇ

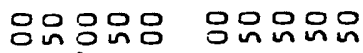
$r-r n$

문문

N $-m$.

는응수

ran

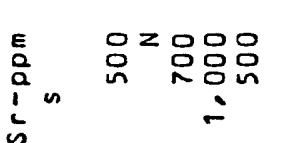

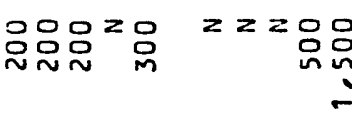

$2 z 2 z$

$z z z z z z z z$

2020

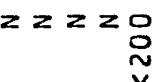

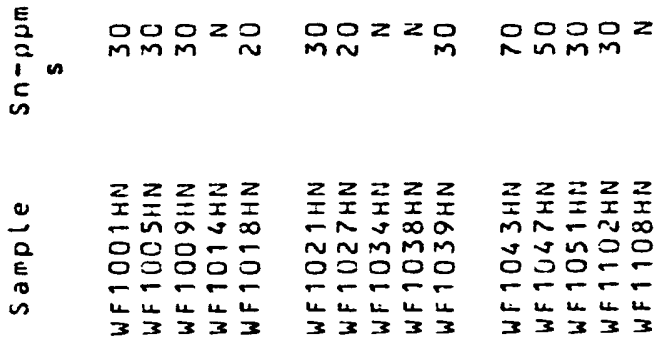

20 엉ㅇ 2

윰ㄹ $z z=2 z z z$

$2 \underset{\sim}{\sim} 2 z z$

$z=\underset{\sim}{O}{ }_{V}^{2}$

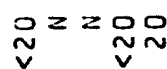

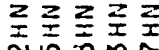
初的品 $-r a n$ Eニテ $3 \frac{14}{3} \frac{4}{3}$
亲示吉 = ma标品 - - 윰

I I I I I 융융ㅇㅁ

다 $5-5-$ $\frac{1}{3} \frac{4}{3} \frac{4}{3} \frac{4}{3}$
I 은든 든 $\frac{14}{3}=\frac{4}{3} \frac{4}{3}$

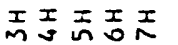
rNNNN $\sim \tilde{N} N \tilde{N}$

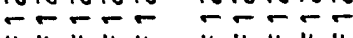

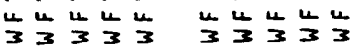




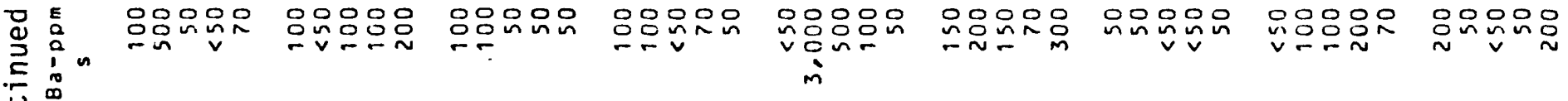

ธิ E ส

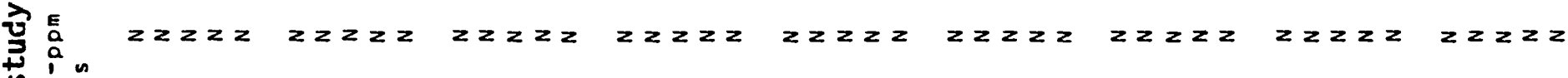
$4-$

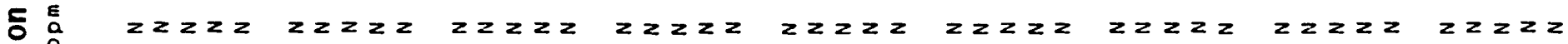

용

4

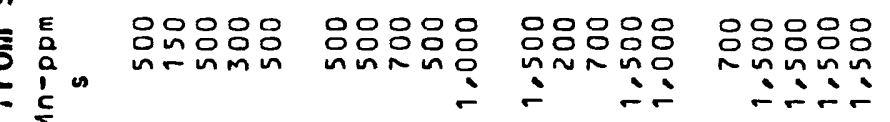

응ㅇㅇㅇㅇㅇ

nONO

옹응응응응

O

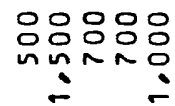

옹ㅇㅇㅇㅇㅇㅇ

응에

응옹응응응

$\therefore$

$\sim$ un no

\&

- 응응응 응응응응

ヘำ

ํㅜㄴ

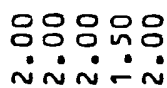

응용ㅇㅇㅇㅇ
눈

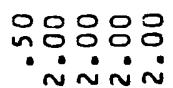

응ㅇㅇㅇㅇㅡ
순

응ㅇㅇㅇㅇㅇ은

은응응요은

응은요응

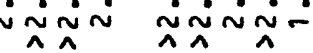
$\sim \sim \sim \sim \dot{n}$

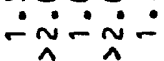

i் $\because \ddot{n}$

U.

00000

00000

00000

00000

00000

00000$$
\wedge
$$

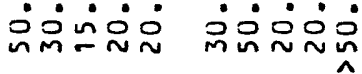

00.00

오ำiO

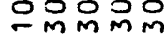

00000

봉ํํ요

00000

mí영

i

ํํำ

mmño

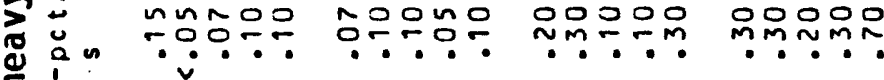

ํㅡ요요

ำกำก

กํํํํํำ

ำํํำำ 응ํํำ

•.?

เ.

․․․․…

c)

ฮ

过:

o onno

oonon

nonoo

On OON

ogono

00000

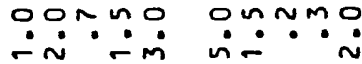

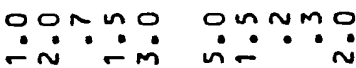

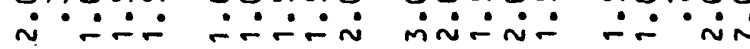

inir-

mimi-:

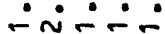

4

n

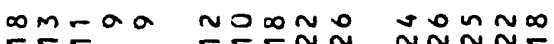

-

$\sim \sim \sim \sim ⿻$

$0=000$

muñm

mog in

armoa

nn $n n n$

nun un

nn $n \backsim \infty$

nnn $n$ n

nnูn纱

nnแn⿺

nunm

นnกำกำ

nnmun

nูnบn⿺

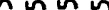

nnn

J

ํㅝ몬

nunun

nn nmm

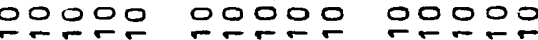

응으은

o00잉

ํํํำำำ

กำำำ

응으은응

แnnแn

으은은은

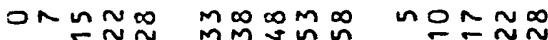

$2=25$

इ $5=5$

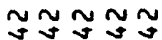

mámo

åmín

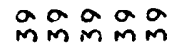

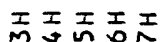

I

$\sim \sim \sim N \sim$

$\sim \approx N \sim N$

$=-5 \div 5$

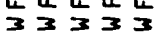

$\sim N m m m$

$\sim \sim N \sim N$

- -5

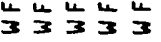

IIIII m $\sim \underset{\sim}{\sim} \sim$

는

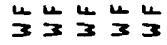

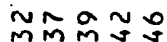

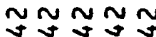

máma

I I I I I

mãa

는는
西称否五

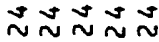

$\because-\simeq$

는 는

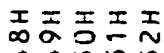

ง $\sim \sim n \sim$

$\simeq \simeq \simeq \simeq$

는는
IIIII

nn nn

$\simeq \simeq \simeq \sim \simeq$

는
II工工采

nn요요

$\simeq \sim \sim \sim \sim$

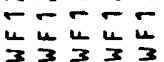

III工元王

웅ㅇㅇㅇ

$\simeq \simeq N \cong$

는 $\frac{1}{3} \frac{1}{3}$ 


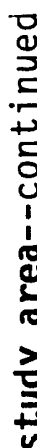

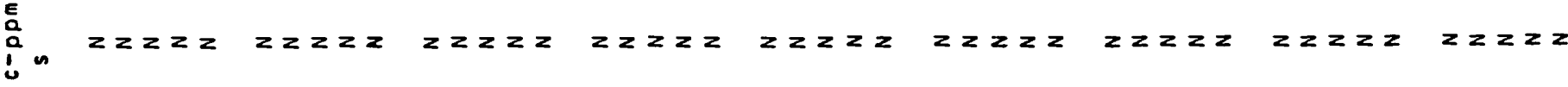

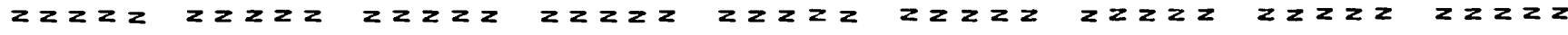

$E$
0
0
1
0
$n$
$n$

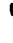

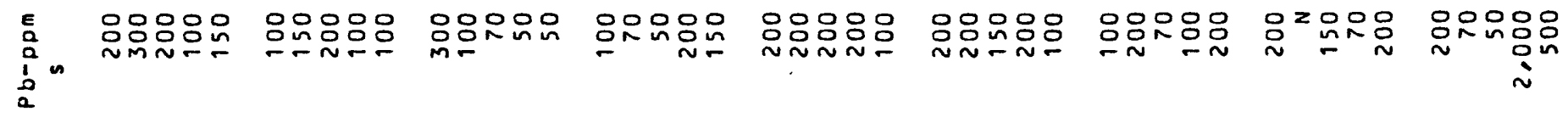

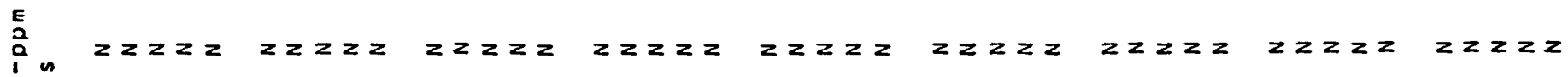

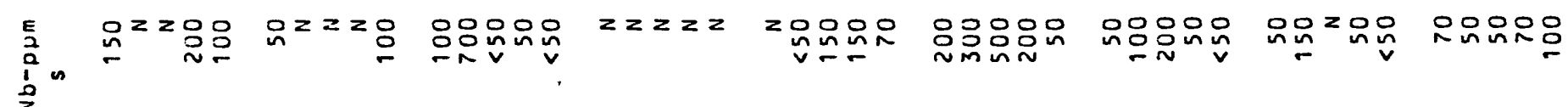
E $\frac{1}{2}$

乌̈ 西

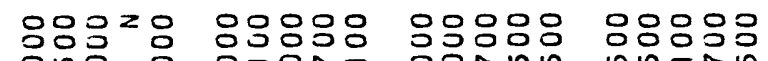

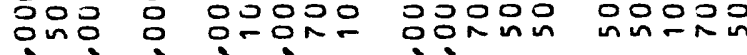
inos

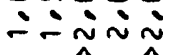

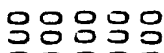
이잉

응요 no:

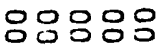

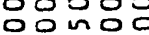

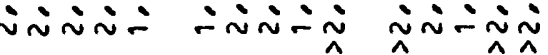

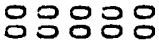

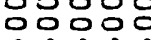

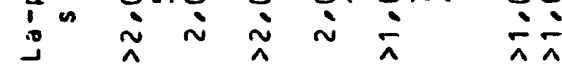

c.

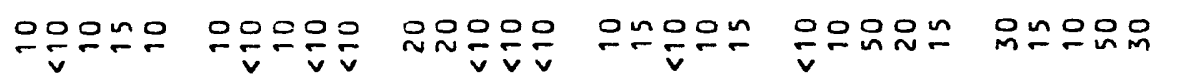

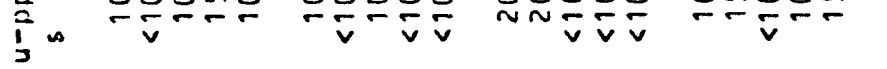

$00 \div 00$

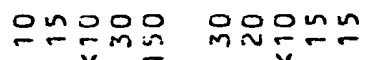



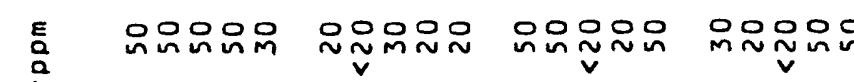

in

Й

(1)

in

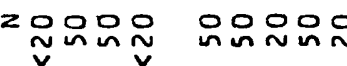

느뉴요요

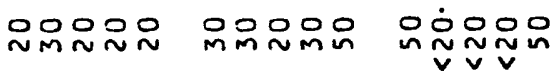

i

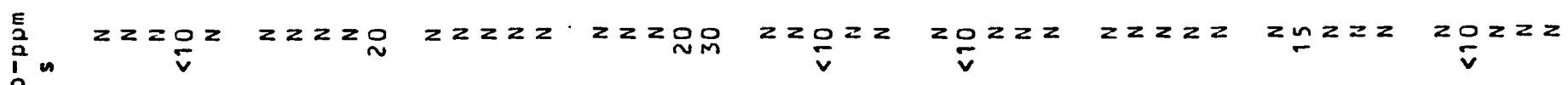
4

운

(2)

.

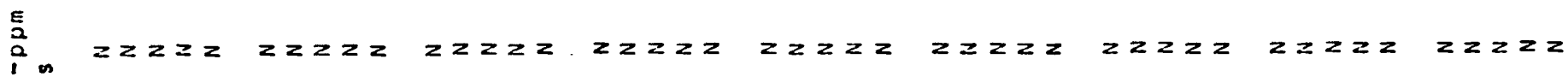
西

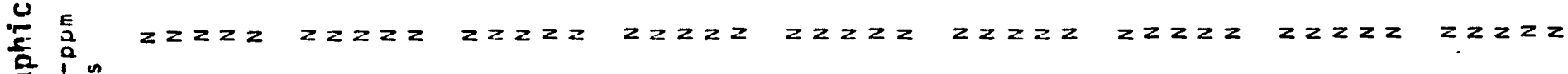

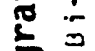

के

岁

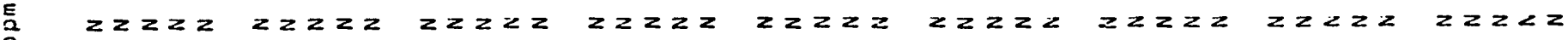

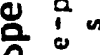

is

崖:

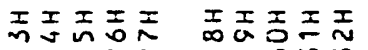

$\sim \sim \sim \sim \sim$

$\sim \sim \sim \sim N$

$\simeq \simeq \simeq \simeq$

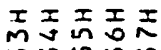

mimmm

$\underset{\sim \sim N \sim}{\sim} \sim$

$\stackrel{\sim}{\sim} \tilde{\sim} \tilde{\sim} \tilde{\sim}$

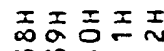

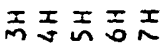

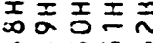

$\sim \sim \sim \sim \sim \sim \sim \sim \sim \sim ⿻ 上 丨$

$\simeq \simeq \simeq \simeq \simeq$

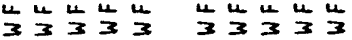

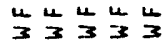

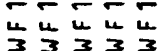

$-r$

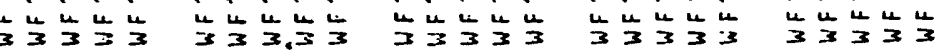

正三台三王

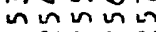

$\approx \sim \sim \sim \approx$

- $-\div$

另云吉项

in $n$ oos

$\sim \sim \sim \sim \sim$

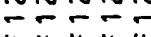

王正台王五 유유유

$\simeq \cong \simeq \simeq$ 


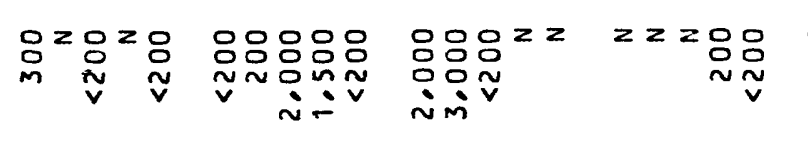

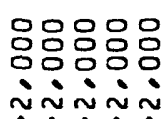

$z z z z z$
응응응음

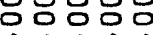
ini i

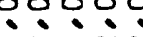
$\sim \sim \sim \sim n$ $\wedge \wedge \wedge \wedge \wedge$
응응응응 ìi் $\wedge \wedge \wedge \wedge$
응ㅇㅇㅇ $z$

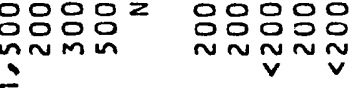

음옹응음

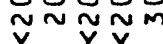

영 $z z z \quad z z z z$

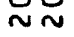

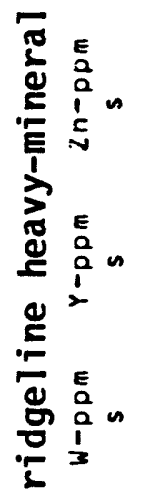

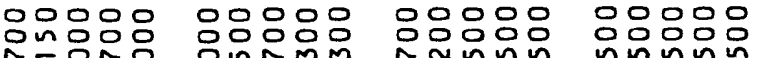
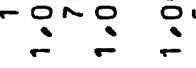

$z z z z=$

$z \geq 2 z z$

n in un

un un un

응ㅇㅇㅇㅇㅇㅇ 늠은묜 $\therefore \therefore$

음음옹음 음응오옷요

음응응응응 $\because \because \cdots$ 응응응응영

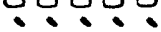
ini $\dot{\sim}$

응응응응응

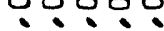
inini

응용ㅇㅇ음

음ㅇㅁㅁㅇㅛ iniñ

응ㅇㅇㅁㅇㅁㅜ $\wedge \wedge \wedge \wedge$

$\wedge \wedge \wedge \wedge$

응요 $\dot{\sim} \dot{\sim} \dot{\sim} \dot{n}$

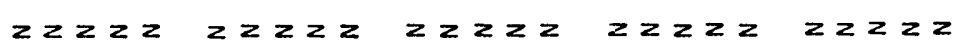

4 $\frac{1}{a}$ ํํํㅇํำ

옴웅응음

$z z \geq z$

$z z z z$

$z \geq z z z$

$z \geq 0 z$ 운

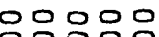

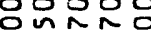

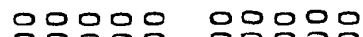
무슷ㅁㅇㅁㅁ

음임음요 $\therefore \because \vdots$



$$
z z z z
$$$$
z z z z \quad z z z z
$$$$
2 z \text { 응욤음 }
$$

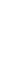$$
z z z z z
$$$$
z
$$

a

旨

는

is

E $0 \geq 000 \quad z z z z 0 \quad z z z z 0 \quad 0 z z 00$

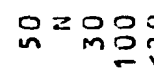

$22<20$

$2 z 2 z \stackrel{0}{\sim}$

$\stackrel{0}{v}^{2} 2 \underset{\sim}{\sim} \underset{v}{\sim}$

zz유 ${ }^{2}$ 응 $z=$

$z 2<2 z$

$z z z z O \quad z z<z z$

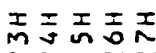

$\approx \approx \approx \approx \approx \pi$

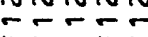

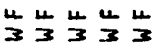

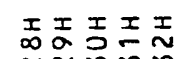

$\stackrel{\infty}{\sim} \underset{\sim}{\sim} \tilde{\sim} \sim$

$\simeq \simeq \simeq \simeq \simeq$

$\frac{4}{3} \frac{4}{3} \frac{4}{3}$

正正贡无

mMmmm

$\simeq \simeq \simeq \simeq \simeq$

$\frac{4}{3} \frac{4}{3} \frac{4}{3}$

I I I I I

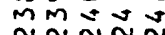

$\simeq \simeq \simeq \simeq \simeq$

崖约能

的寺无吉走

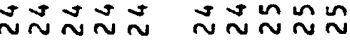

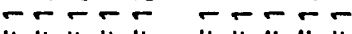

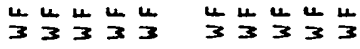

I

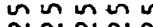
-

드는

I

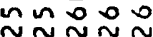
$\simeq \simeq \sim N \simeq$

프는

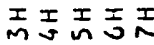
원유유

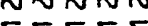
든픈 


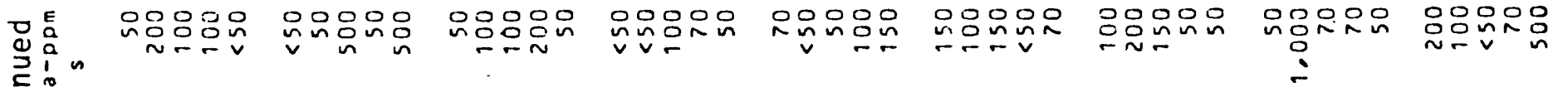

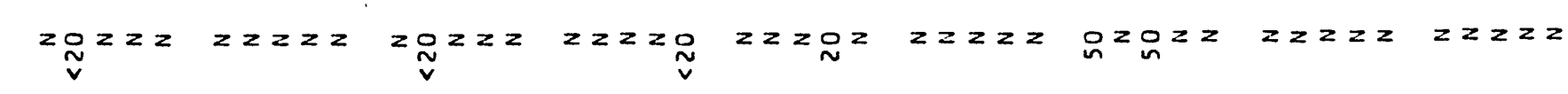
$z z z z z \quad z z z z \quad z z z z \quad z z z z z$ zzzo

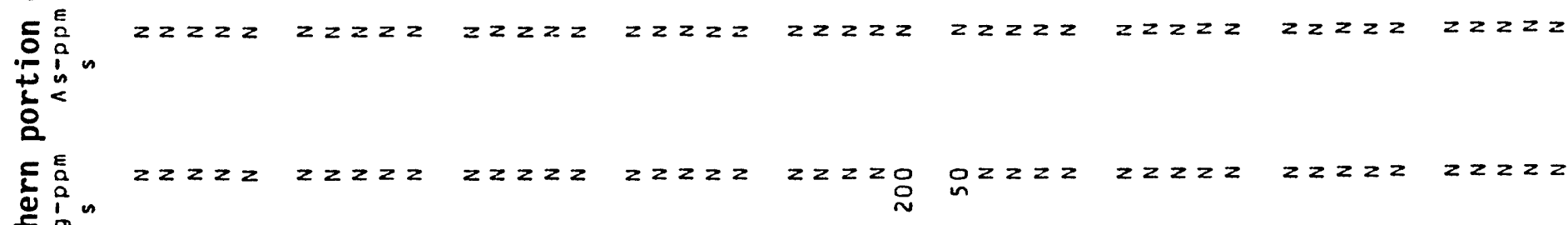

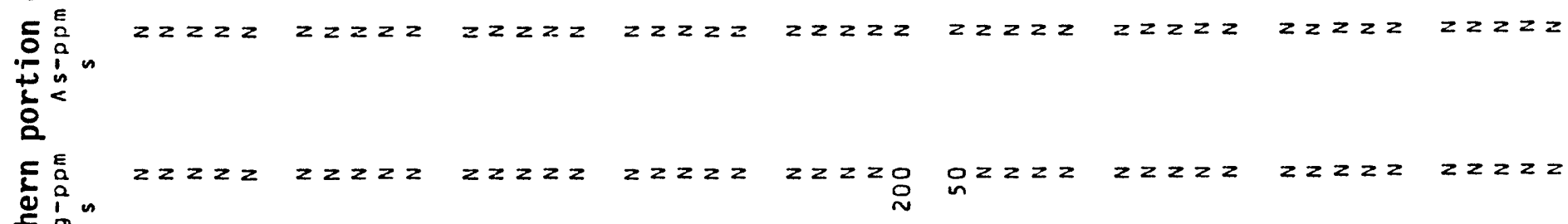

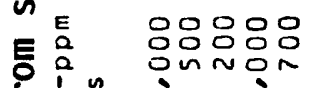

응응응 응응응 응응응

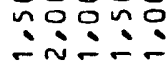

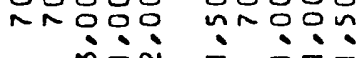

응응음 는문

음음웅음 nnun

응응응음 mํำ

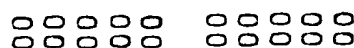
min $\therefore$ : $\therefore-\div$ $\therefore$ 응ㅇㅇㅇㅇㅛ

응응응 응응응

응응ㅇㅇㅇ

음용요용

inin $\dot{\sim}-\dot{\sim} \dot{\sim} \dot{n}$

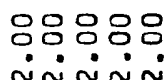

응으요요

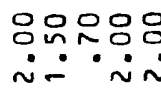
$\underset{\wedge}{\sim} \dot{\sim} \dot{n} \dot{\sim} \sim$

응응음 ininin

용요음

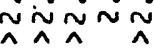
$\wedge \wedge \wedge \wedge$ $\wedge \wedge \wedge \wedge$

00000 00000

00000

00000

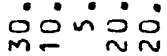
용용 - $\dot{0} \dot{0}$

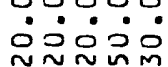

00000

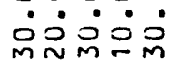

.000.0 믄ㅇํํ

0.000 穴完完品

00000

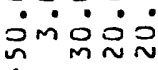

00000

ํํำ?

onก $\because$ ?

$\because \because n$ ก

กกดก

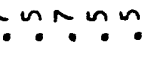

$\checkmark \infty \sim m m$

กงัำ เที่ง

드응 $\sim \sim \sim \sim \sim$ mumm

nun nun 으으으으응

nunum 응ㅇㅇㅇㅇㅇ

$\tilde{\sim} \sim m m m$

กnบn⿺

$m \sim \sim \sim \sim$

응응

nnแn⿺

은으응응

이는 ơy y y

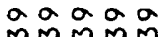

nㅇำํำ

$\approx 0=0-$

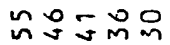
ตูก

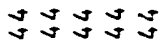

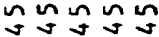

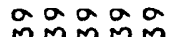

aำ aे ตำํำ

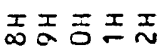
$\stackrel{N}{N} \tilde{N}$

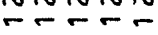
는

IIIII MN N $\tilde{n} \tilde{N} \tilde{N}$ 든든

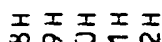

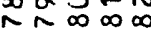
$\sim \sim \sim \sim N$ $-\sigma-5$ 级落落
II工贡另 $\infty \infty \infty \infty \infty$ $\sim \sim \sim \sim \sim$

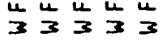
- $-\div--$
กOำ Jु m M

นก๊กำ

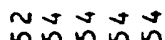
แกแนกต 으으응은

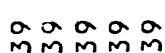

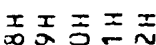

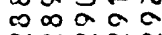
$\sim \sim \sim \sim N$

는

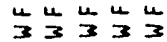

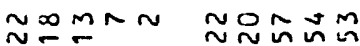

오Mำ

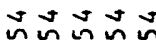
nunun 응으응응

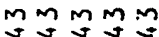

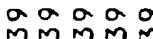

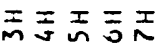
웜응 N 는 น⿻上丨

กั่ ํำนที numun 은으은응

은ำ는

åma

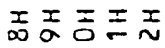
도이은 NMMm 느는 $\infty m-n$ nน 000 n๓n⿺⿻一𠃋十 nnnnn 으느음으응

amann इ $2 \overline{2}$ màma

III I I I 엉ㅇㅇㅇㅇㅇ M M M $\frac{4}{3} \frac{4}{3} \frac{1}{3}$
욨ํำ ํํํํํํํำ กแกnน 으응으은?

$\stackrel{\sim}{\sim} \sim \sim$ 2.272

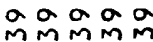

II I I I 이음든 - - -

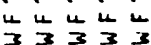




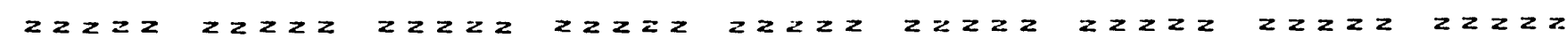

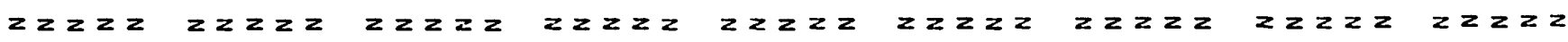

응ㅇㅇㅇㅇㅇㅇㅗ

옹웅응ㅇㅇㅇㅡ

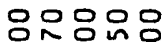

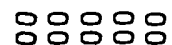

응ㅇㅇㅇㅇㅇㅇㅡ

은응응ㅇㅇㅇ

옹용요윰

음음웄웅음

음응응음

$4 a^{2}$

-mo

n-

NกNNN

N $\mathrm{m}$ in

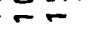

$\sim m m$ in

in $m$ N

동

党

$z=$

$z \geq \geq z$

$z 2 z 2$

$z z z z$

$z \geq z z z$

$z z z z$

$z z z z$

$z 2 z 2 z \quad 2 z 2 z 2$

㝴

응응ㅇㅇㅇㅛ 유숨ㅇㅁㅇㅇㅡ

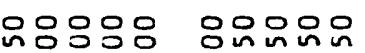

0000요

응을 2

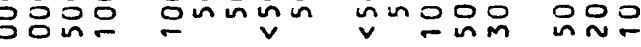

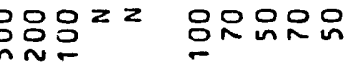

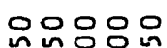

$\ln 00$

애을 $z=2$

竞

京

$z z z z z \quad z O z z$

$z z$ 品咞z $z z z z z \quad z z z z$

융유 ${ }^{2}$

느응으응으

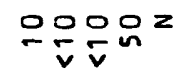

웃음온

4.

옹응웅응

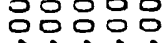

i்亡心்

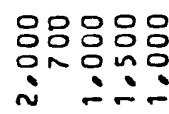

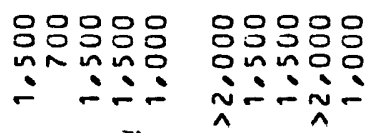

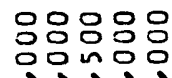

$\wedge \wedge \wedge$

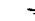

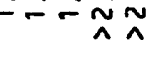

응웅ㅇㅇㅇㅇㅇㅇ

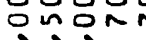

$\dot{n} \div \dot{n}$

웃ㅇㅁㅇㅇㅁㅇㅁㅇㅁㅇ

in

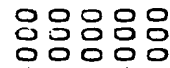

$\therefore \sim \sim N N$

웅웅응ㅇㅁㅁ

0000 品

iñ

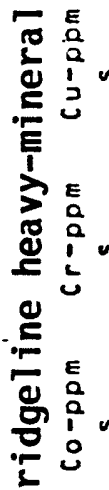

웅읍으느 은은은

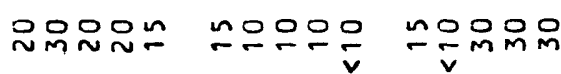

은요용

으은은

는은은

은으눈

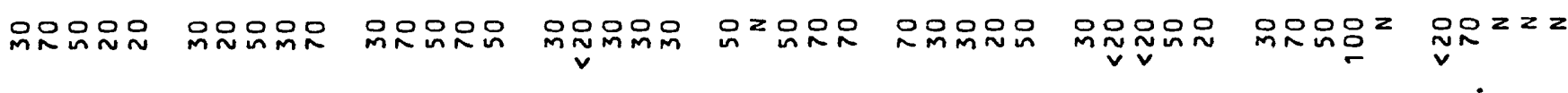

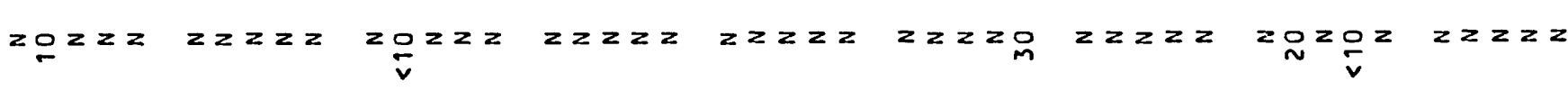

4

u 2

in $\frac{a}{1}$

$z z z z \quad z z z z$

$z z z \geq$

$z z z z$

$z \geq z z$

$z z z z z \quad z z z z z$

$z z z z z \quad z z z z z$ $z \geq z z z \quad z z z z$

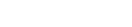

$2 z 2 z$

$z z z z z$

$z z z z$

$z z z z z \quad z z z z z$

$z z z z z \quad z z z z$

韋

$z z 2 z$

$z z z z$

$z z z z z \quad z z z z$

$z<z<z$

$z z z z$

$z z z z$

$z z z$

$z 2 z z z$

조옹폰 ogiñ $\simeq \simeq \simeq \simeq \simeq$

两采正台贡 añN $\sim N \sim N N$

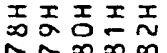

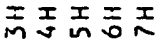
$\hat{\sim} \approx \sim ⿻ \infty$ $\simeq \simeq \simeq \simeq \simeq$ $\infty \infty \infty \infty \infty$

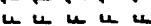

$4=5 \overline{4}$

$\because-\sim \simeq \cong \simeq \simeq \simeq$

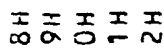

in $\infty$ o 0 a

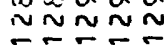

33333

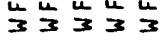

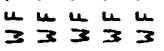

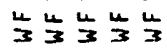

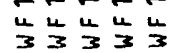

III工壬台I

웜임

$\simeq \simeq \simeq \simeq$

$\frac{4}{3} \frac{4}{3} 3$

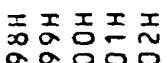

이뭉요

는

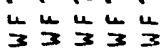

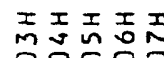

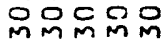

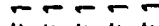

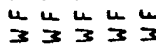

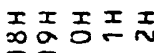

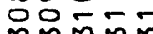

mmmmm

는는

$3 \frac{1}{3} \frac{4}{3}$ 


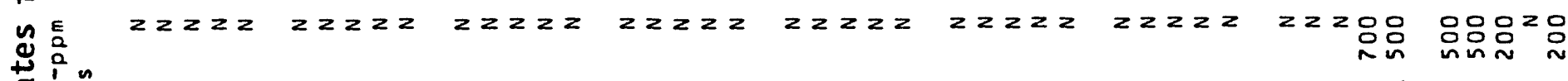

\section{응응응응 응응응응}

inin iñin

웅응음

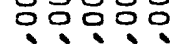

$\dot{\sim} \approx \dot{\sim} \approx$

응응응ㅇㅁㅇㅇㅇㅇ

음음응응음

iñi்

inini

음옹응웅

0000

$\wedge \wedge \wedge \wedge \wedge$

$\sim \pi N \pi N$

$\sim \wedge \sim \sim \sim$

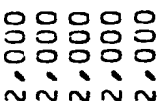

응응응응

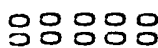

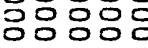

ini $\dot{i} \dot{x}$

inini

$\wedge \wedge \wedge \wedge$

$\wedge \wedge \wedge \wedge$

$\wedge \wedge \wedge \wedge \wedge$

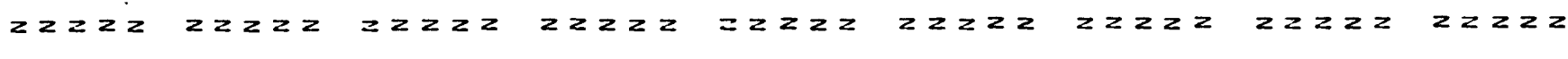

$2 z z 2 z z 2 z z$

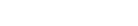

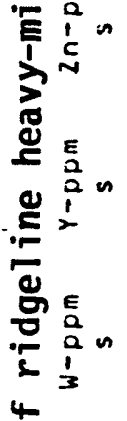

4

in

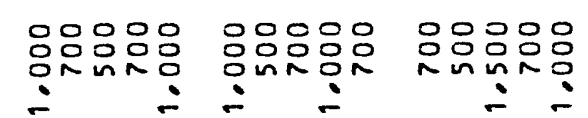

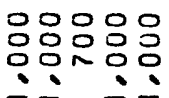

응잉ㅇㅇㅇㅇㅇ

응엉ㅇㅇㅇㅇㅇ

읏은요

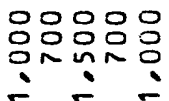

잉응응ㅇㅇㅇ

응ㅇㅇㅇㅇㅇㅇ

$\therefore \therefore=$

$2 z 2 z$

$z z z z$

$\frac{0}{0} z=2 z$

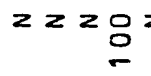

$z z z z z$

$z=2 \geq 2$

$2 z 2 z z$

促

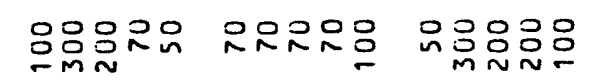

은응요은

응으는옹은

응으는옹요

응근응으음

올은용ㅇㅇㅇ

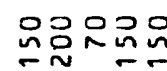

$z z z z 2 z z z$

$2 z 22 z$

$z z \geq z z$

22222

$z z 200$

$z=z z \circ$ 응

옹옹영옹응

0

등 i

ס

$E$
$a$
$a$
$\vdots$
$c$

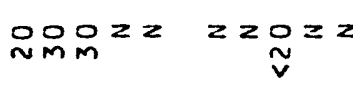

zQㅁㅇㅡ

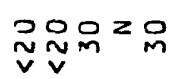

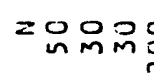

응요울

$\mathrm{M}_{\mathrm{O}} 20=2$

20 이은

이의 $z z z$

ㅇํㅇ IU IIIIII IIIIII

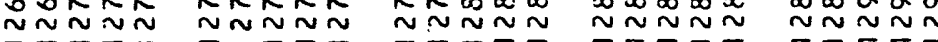

$\simeq \simeq \simeq \simeq$

-드.

$\sim-\infty$

I I

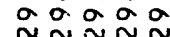

$\simeq \simeq \simeq \sim N$

जद $=5 u$

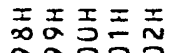

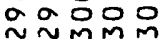

$333 \div 3$

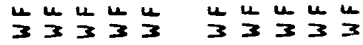

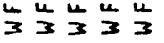

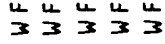

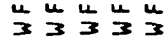

$\simeq \simeq M m$

यद यू द

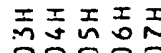

었은을

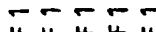

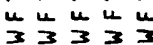

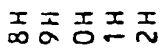

이믐

mMmmm

$\frac{4}{3} \frac{4}{3} \frac{4}{3}$ 


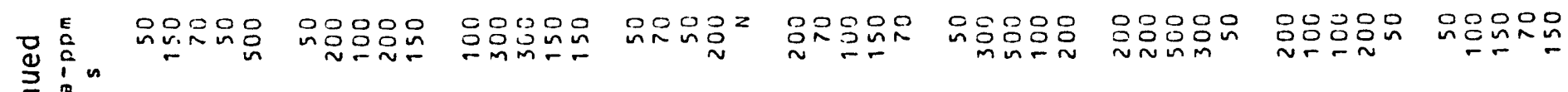

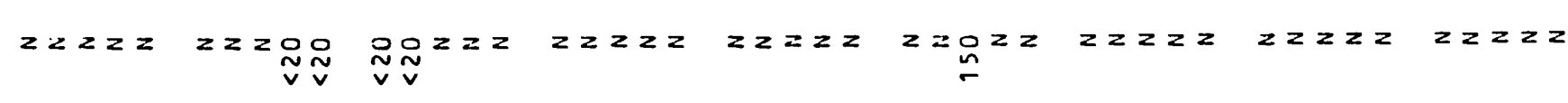

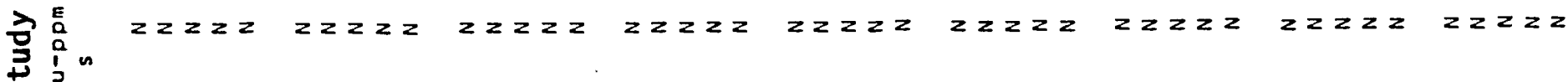
4

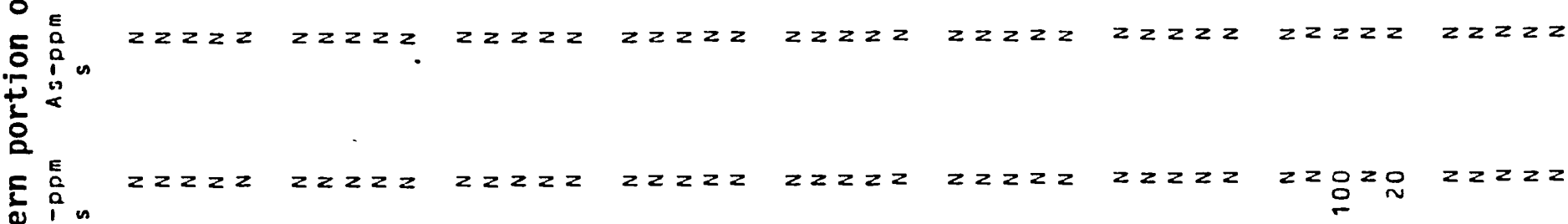
E 选 $\sum^{2}=$

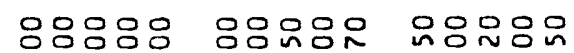

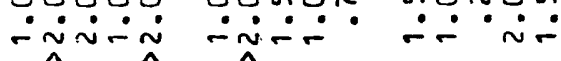
은ㅇㅇㅇㅇㅇㅇㅇㅛ

응옹응ㅇㅇㅇ 용

$\ddot{\sim} \dot{\sim} \dot{\sim}-$

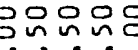
$\ddot{\sim} \div-\div$ 요요ำ U

톨

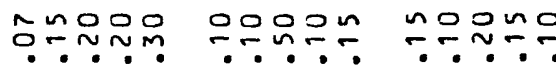
in $\dot{m} \dot{m}$ mión

$\because 0000$ 克夜只品

0.0000

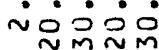
กิธย์ำก

응유는

(1)

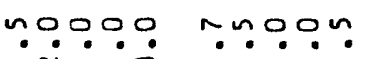

O. in on ก0.0 $\because 00 ?$ ?

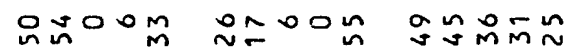

으스묘

nnn nun

ㅇํㅇํㅇำ

กัm

$2 \pi \operatorname{zin}^{2}$

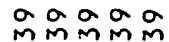

$\infty \infty n$

$n_{n \rightarrow \infty}^{\infty} \underset{n}{\infty} \tilde{n}$

nกแกn

은은은

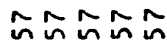

nnnmu

은은은

ํํำำ $\simeq \sim \simeq \sim \simeq$

aarao

लmm in ñor-

ปู

$a$
mm ma요

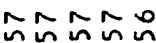

nกnแn 은으응

$-\infty m=0$

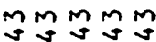
ana a a लिलmm

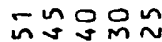
ํํํํำ ํำ

nกแnน 음응응

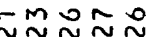
MM M M ज мåmi

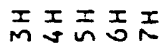
든 mmin 岁药玄玄
IIIII $-r \sim N \sim$ Mmm 는는

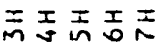
$\tilde{M} \tilde{M} \tilde{M}$ $-\leftarrow$ 는 $\frac{1}{3} \frac{u}{3}$

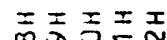
MMmMM MMMmM 는

ำ ․․․․․․ 응옹유옹응 $\dot{\sim} \dot{\sim} \dot{\sim}$

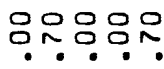
ํํำ

옹응ㅇㅇㅇㅇㅇㅇ

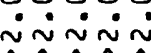
응응ㅇㅇㅇㅇㅇㅇ

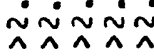
은유문

\section{-}

은은

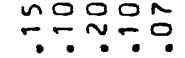

noo0o ำ? on mo :0000 $\because \because \sin$ nomoo - nn $n-m m \sim$

이웅 نே 00000

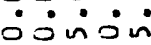

믄 ing

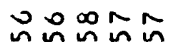
nnm nn 응응은

赵品只 mizez

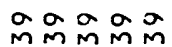

งิณñ

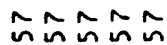
n๓nแn 은응은

ก̊mMn ㄱ․ㄷ․ araa mimm $=\infty v 0$ n กิ่ง ถูก

nnnnn o0000
은ำำ MmMmm

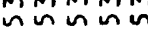
nnnun 은은은

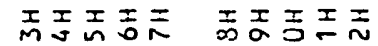
MMMmM MMMNMN 든 - -

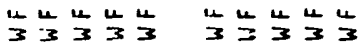

I I I I I I

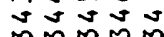
m- - -

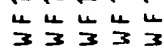

mag जुgु

araara mimm
ำ

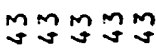
araa 


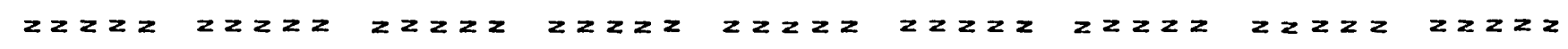

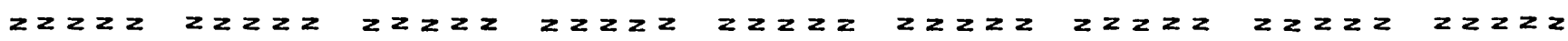

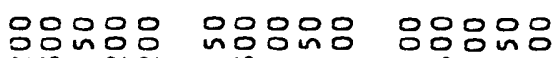

\begin{tabular}{cc}
$n$ & $E$ \\
4 & 0 \\
0 & 0 \\
\hline & 0
\end{tabular}

品

minn

- 웃ㅇㅁㅇㅇㅁ

음운응응으

음유수음음

음웃오온

응음음응음

5

‘

용

in $\quad z z z z$

$z z z z 2 z z 2 z$

$z z 2 z 2$

2222

$z z z z$

$z \geq z 2 z$

$z z 2 z 2 \quad z 2 z z z$

돈

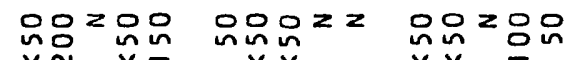

1 $\frac{1}{2}$

ํํำ응

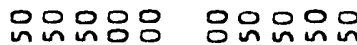

ที่ำㅇำ

ำง vin

잉ㅇㅇㅛ

유융ㅇㅇ을

음음윰용으

2 은응요

VกN

E

乡

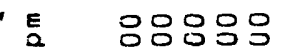

응음음

$\dot{i} i \dot{n}$

응응음응응음웅 nom

$\therefore \therefore \therefore$

응ㅁำ

in

응음응음

rọn

옹음응음

on nn

洼泫

음응옹음

in:

$\pi \approx$

옥응응음

긍웅요

응옹옴음

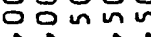

응음옴음

$\therefore$ i

$\therefore \dot{\sim}:=$

oonou

i் i

总

n

in a

$z z z z z \quad z z 2 z \quad z 2 z z z \quad 2 z 2 z z$

$z z z z z$

$z z z z z$

$z z z z z$

$2 z 2 z 2 \quad 2 z z 2 z$

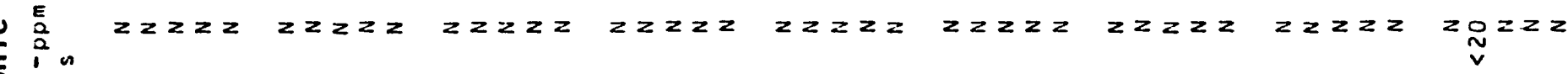

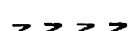

$z z z z 2 \quad z z z z z \quad z z z 2<$

$z z z z$

22000

OP $z 20 z z z z z z z z$

否三士口元 กิกีmmm

$--5-5$

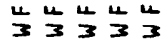

资寺三台台 MMMMMM

MmmMn

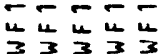

I $m m \dot{m}$ mmmm 드는 3333
另王台台台

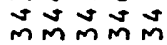
드는

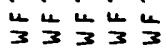

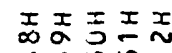
的的絔出

एँ

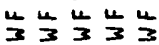

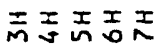
nununin mminm 든 


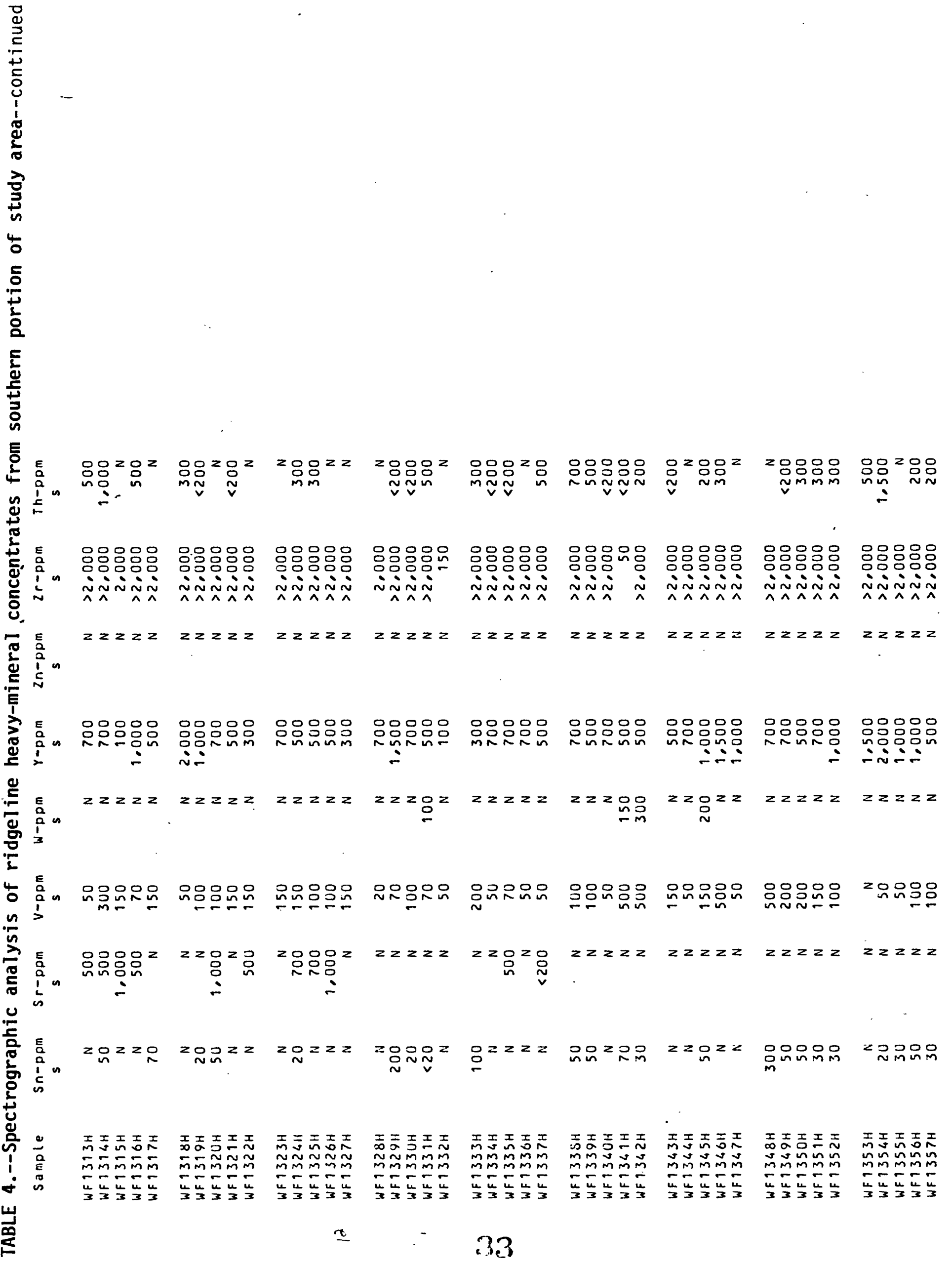




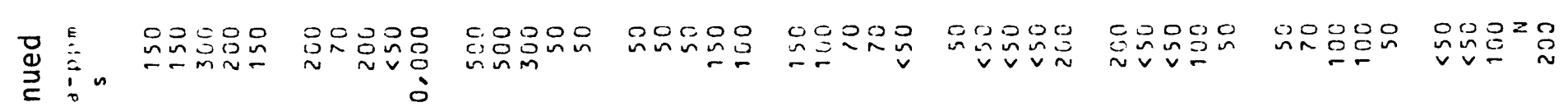

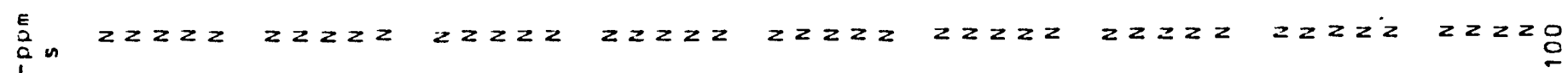
c

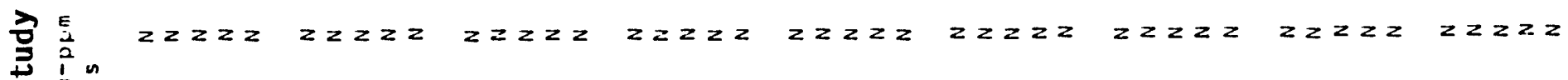

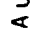

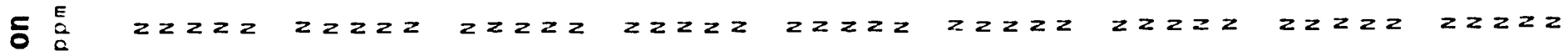

$z-z z 2 \geq z z z \geq$

$\operatorname{nn} z z z$

$z z z z$

$z z 2 z z$

$z 2 z z 2$

$z 2222$

$z z z z z \quad z z z z z$

응응음응 응응음음 응영응응

ninmm

un nin

nmm in

응응ㅇㅇㅇㅇㅇㅇㅇ

응응응응웅 nonn? 욘?

응응응응응 un in un

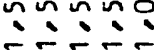

응응응응응 능요

응응ㅇㅇㅇㅇ

응응ㅇㅁㅇㅇㅁ응 ह

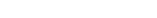 \\ 응응ㅇㅇㅇㅇㅇㅇ}

(1)

in $\operatorname{nn}:$

등응ㅇㅇㅇ 응융요 용ㅇㅇㅇㅇㅁ

$\dot{\sim} \sim \dot{\sim} \dot{\sim}$ $\ddot{\sim} \ddot{\sim} \div-$ $\stackrel{\sim}{\sim} \dot{\sim} \sim \dot{\sim}$

응ㅇㅇㅇㅇㅇ
순்

응옹ㅇㅇㅇㅇㅇ $\wedge \wedge$ $\wedge \wedge \wedge$

00300

00000 00000

$\because$ ㄸํㅇ $\dot{\sim} \dot{\sim} \dot{\sim} \dot{\sim}$

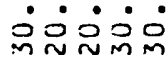

0.0.0.?

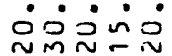

00000
$\dot{M} \dot{\sim} \dot{\sim} \dot{m}$

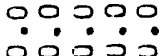

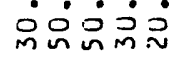

$\stackrel{0}{0}: 0.00$

$\dot{\sim} \dot{\sim} \dot{\sim} \sim \dot{\sim}$

웅응ㅇㅇㅇㅇㅇ

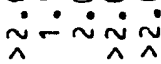

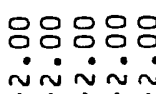

응응ㅇㅁ응 ำ $\wedge \wedge \wedge \wedge \wedge$

ว.․․․? $\dot{m} \dot{\sim} \ddot{n} \dot{n}$

0.000

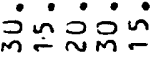

ํํำำ ํํํํำ

응은ํำ

므는믄

은으으.

ํํํํำำ

으ํํํำ

ํํํํํำ

๓กำกำ 2

oodoo onomo coooc min vim $\dot{m} \dot{0} \dot{0}$ óm-n

odinoo

co우

nonoo

c n m ?

๓0.000

- imí.

onn mo ñ ñ vimin

wnsta nin-ma

min

$\sin 2 \pi d$

$\sim n \sim-$

$\because \infty \sim \stackrel{\sim}{\sim} \bar{m} \tilde{m} \stackrel{m}{m}$

I는 $n-r$

ปก⿻上

$\tilde{\sim} \sim \sim m \sim$

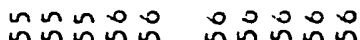

ํํํํำ

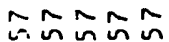

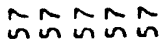

$\cos 20$

nn $\operatorname{nnn}$

$n \pi n n n$

$\operatorname{nn} n \min$

nn $n \sim n n$

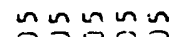

nunun

nnnun

은은은

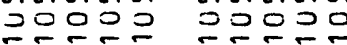

은응

200은

긴은

ถึก.ด

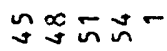

느느으ำำำ

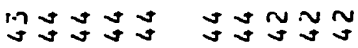

2 $2 \mathcal{2}$

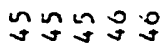

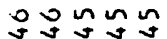

âma

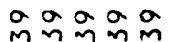

ติ

araa

लिखं

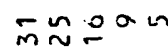

nin $n$ in

- ำํำ

$\stackrel{\sim}{\sim} \sim \mathcal{M} M$

ปูป ปู

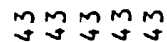

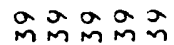

ân

màm

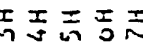

らัฐエII

थलि

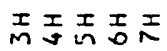

Mำ

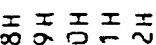

I I

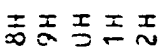

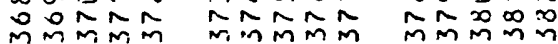

드는는는

- - -

는

는

$\infty \infty \infty \infty \omega$

MMMMM

는ㄷㄴ는

II工五工王 $\infty \infty 0$ un mmus

는든

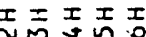
证的的 งy vos

ヘーーー

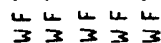

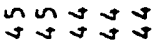

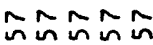
nnmun 근은은

m以MD mm magma

I立无吉五 nun un 뇐 는 $3 \frac{4}{3}$ 


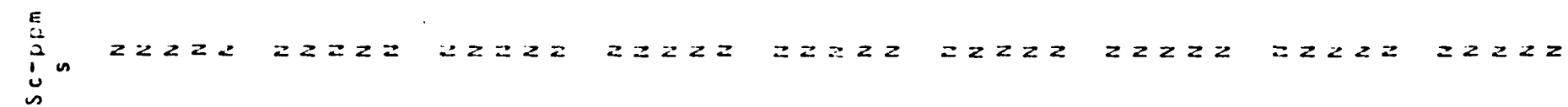

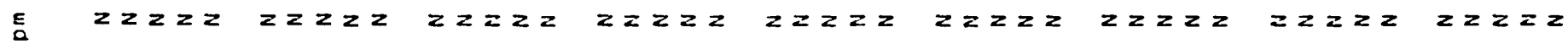

은응ㅇㅇㅇㅇㅇ 응ㅇㅇㅇㅇㅁ

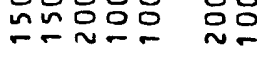

:

n

웃옹으은

음음우요 움웅응

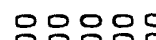

음웃응응

곡웅응으 은음응으

ธิ์

苋

i

$z z z z 2 z z z z \quad z z z z$

$z z z z z \quad z z z z$

$z z z z$

$z z z z z$

$z z z z z \quad z z z z$

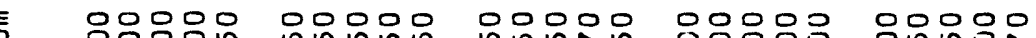

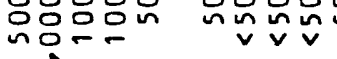

in :

틍

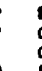

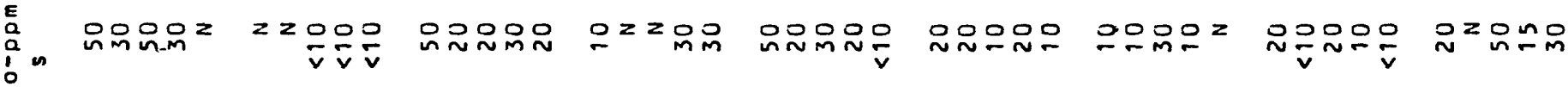
$\sum^{\circ}$

\section{응응응음}

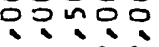

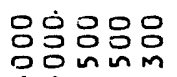

in

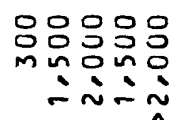

응응응ㅇㅇㅇ음

bo

$\dot{i} \dot{i} \dot{i} \dot{n}$

응윰욤용ㅇㅁ

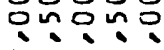

옹응음

이잉

inin-

영ㅇㅇㅇㅛ

ำ?ำ

$\because \therefore \dot{\sim}:$

긍응요용

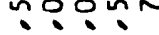

응ㅇㅇㅇ음

nNo욤

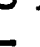

20

.5

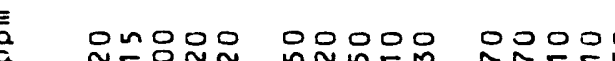

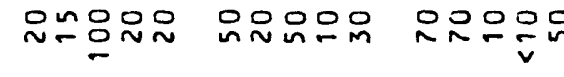

oningo

00000

on

o0, 000

isin

$-n$

은

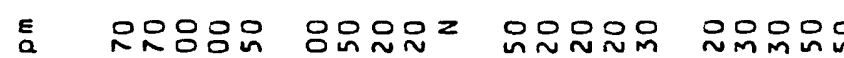

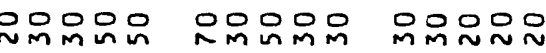

온유ㅇㅛㅠ

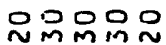

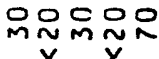
in $\sim F$

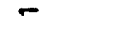

$\checkmark v$
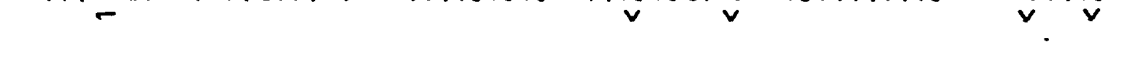

$z z z z$

$z z z z$ 品

읐윰으 $z=$

$z=2 O_{n}$

$\frac{0}{v} z z z$

$z z z z$

$z \geq z z z$

$z z z z=z z=2 O_{n}$

4

in

$z z 2 z z \quad z z z z \quad z z 2 z z$

$z 2 z=2 \quad 2 z 2 z$

$z z z z=$

$z z z \geq z$

$z z z z z \quad z z z z z$

赵

U

$z z z z$

$\underset{\sim}{\stackrel{O}{v}} z=2 \geq z 2 z 2$

$z z 2 z$

$z z z z z$

$z \geq z \geq 2$

$z z z z$

$2 z 2 z 2 \quad 2 z 22 z$

。

$\frac{5}{2}$

$z 2 z 2 z \quad z 2 z 2 z \quad 2 z 2 z$

$2 z<z$

$z \geq 2 z z$

$z \geq 2 z 2$

$z z=z z$

$<z z z z \quad z<z z z$

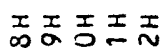

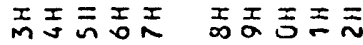

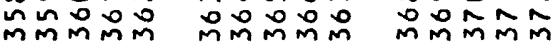

-5--5 --

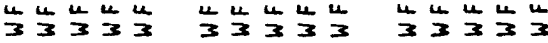

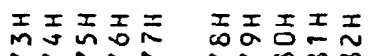

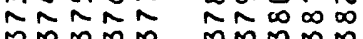

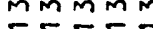

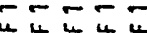

MMMm

는

I $\infty \infty \infty$

mMMmm

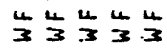

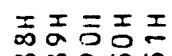

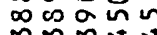

mina

는

王王王无吉

ññ

ㄷำ

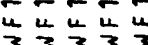

I I I I I I

nin

-

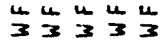

3

3.5 
응옹응옹요 눈윰ำ

点

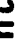

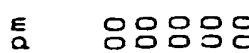

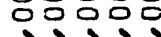
iñ $\sim$

$z z z z z$

$z z z z z$
옷윰유 $\mathbf{v}$

응응음응

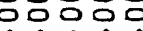
$\approx \sim i \sim i$

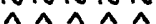

\section{응응응응음}

몸ㅁํㅇ inini $\wedge \wedge \wedge \wedge$

음음음음
음옷옹음음

$z z \geq z$

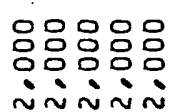

응응응응음

$\dot{\sim} \dot{\sim} \dot{\sim} \sim$ $\wedge \wedge \wedge \wedge \wedge$
음암옴음
음음음음음

옹웅ㅇㅁㅇㅇㅁㅇ

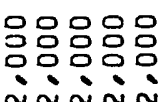
$\approx \wedge \approx$

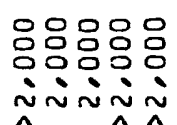

ヘ N N
양응응응영 iñin $\wedge \wedge \wedge \wedge$

$z z \geq z$
옹응음

noo잉 $\therefore \dot{\sim} \dot{\sim} \dot{\sim}$ $2 \geq 2 z 0$

. $a$

E 음웅음

읏은옷음은

응응응응응

응응ㅇㅇㅇ

잉ㅇㅇㅇㅛ

응응ㅇㅇㅇ

$z z z z z \quad z z 2 z z$

in수음

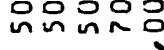

옹응ㅇㅇㅇㅇ음

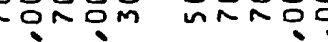

$\therefore$ -

的n

옹ㅇㅇㅇㅇㅁㅁ음

noㅇㅁㅇㅛ

i i

응응응음

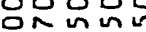

$\therefore$

웅ㅇㅇㅇㅇ

옹ㅁㅇㅇㅇㅁ

Nㅡㄴ

$z z z z z$

응ㅇㅇㅇ

$z z z$

$z \geq z z$

$z \geq z z$

$z z z z z \quad z z z z z$

$z z z z$

$22=22$

$\frac{2}{2}$ os

23

4

$\because \frac{E}{a}$

$\operatorname{sen} 100$

응웅유은은

옥옹으웃

음웅응묘음

궁ㅇㅁㅇㅇㄱ 운웅으

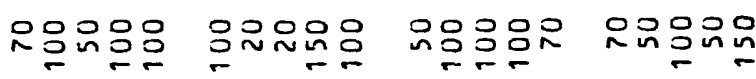

$z z z z$

$\mathrm{O}^{2} \mathrm{~g}=0$

$z z z z$

$z \geq z z=$

$z z 2 z$

$z z z z$

$z z z z z$

$z 2 z 2 z \quad z 2 z z 2$

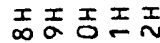

nn

mmmmm

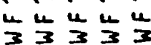

IIII工品

0.00 .00

mmmmm

든ㄷㄴ

IDIJII

Mํํํํำ

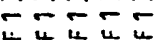

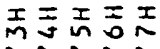

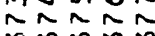

$m m m m m$

$\frac{4}{3} \div 3 \frac{4}{3}$

IIIII $\hat{n} \sim \infty \infty \infty$ 的的的

is

II I I I

$\infty \infty \infty \infty$

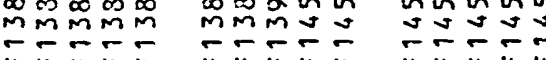

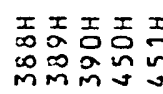

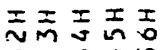

us $=-\pi$

ü üu

$\frac{u}{3} \dddot{3} 3 \frac{u}{3}$

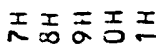

nin

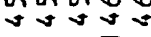

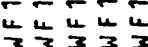

\section{'}




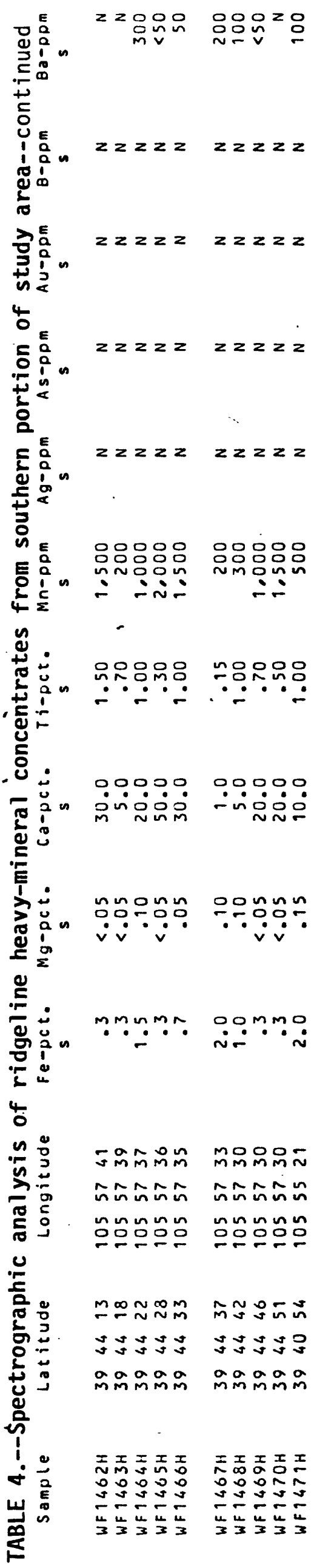



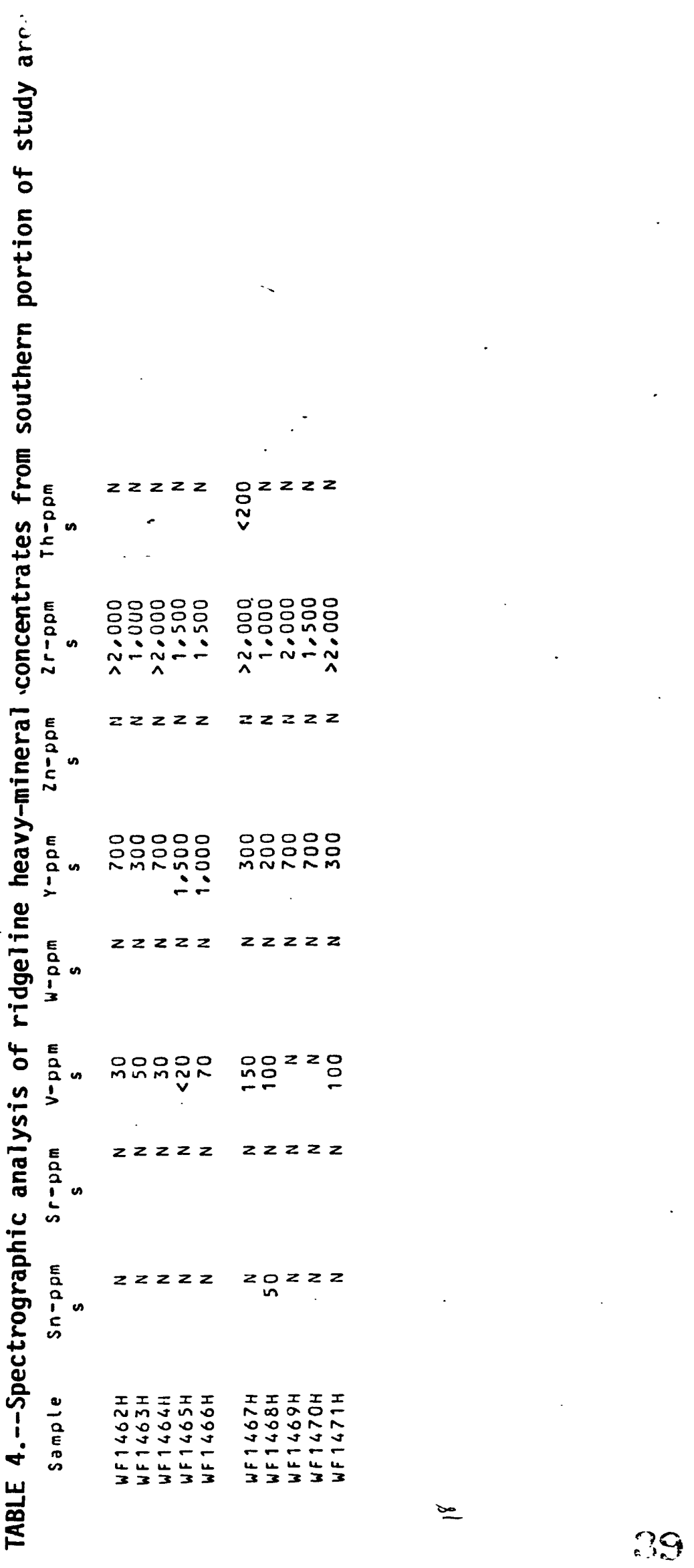


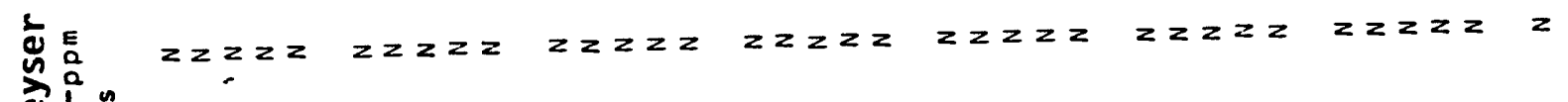
电

통

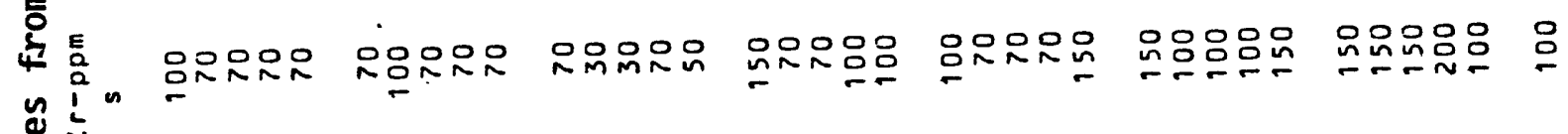

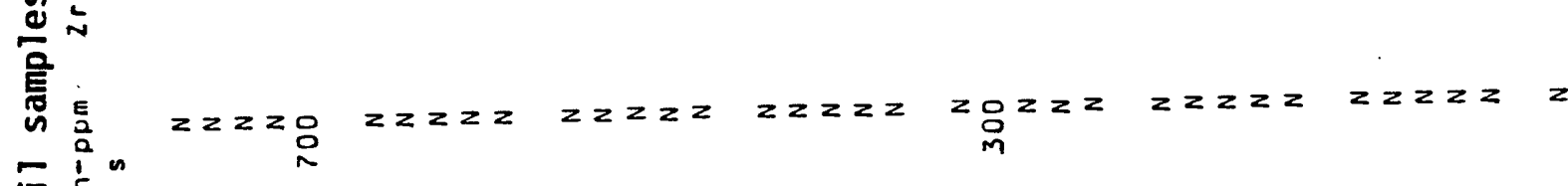
- 5

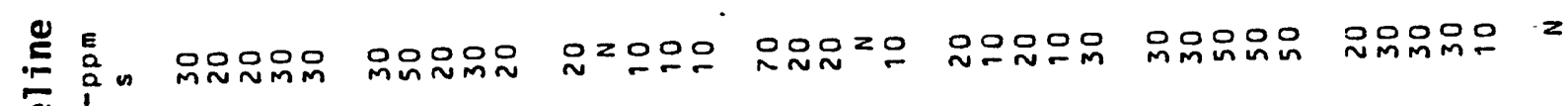
(2)

응

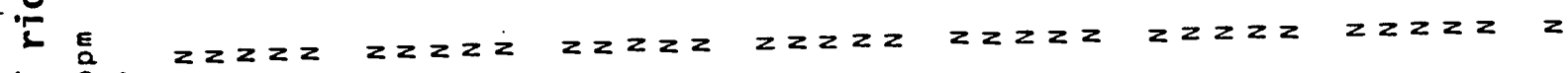
$4 \stackrel{2}{1}$

$\frac{n}{n}$

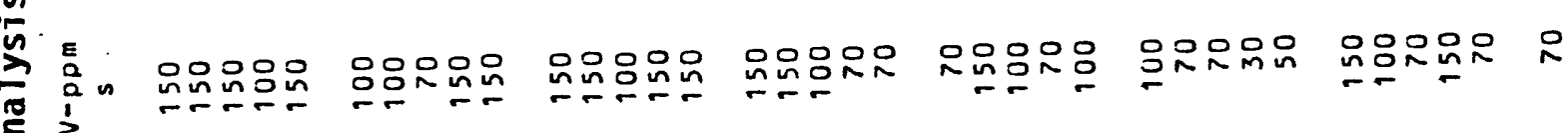
$\sum_{0}^{\infty}$

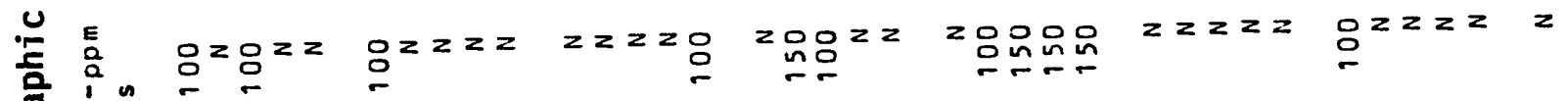

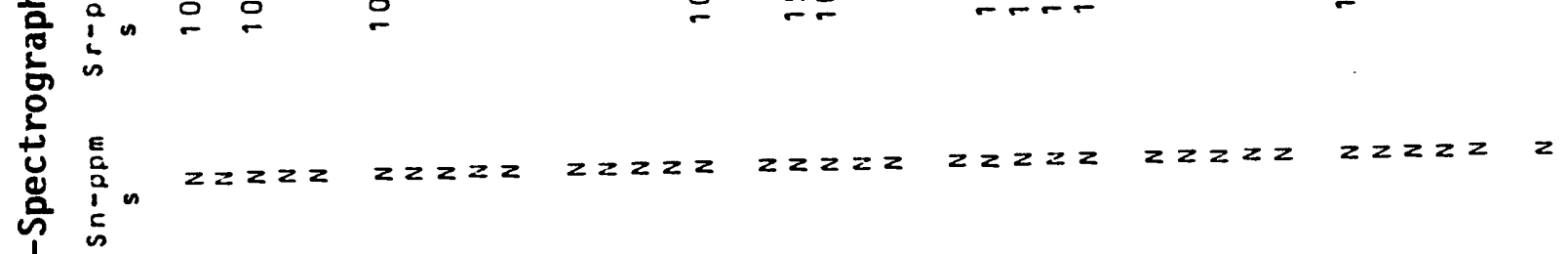

은요요용 웅ㅇㅇㅇ 잉ㅇㅇㅇ

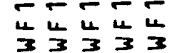

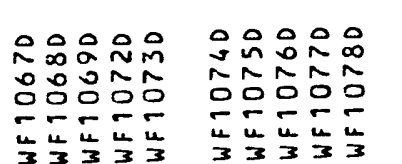

m

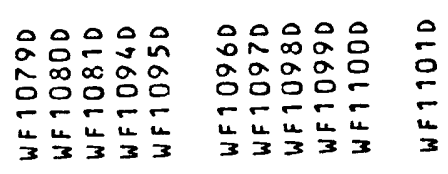




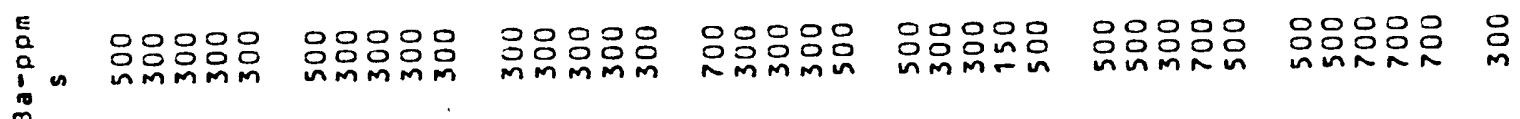

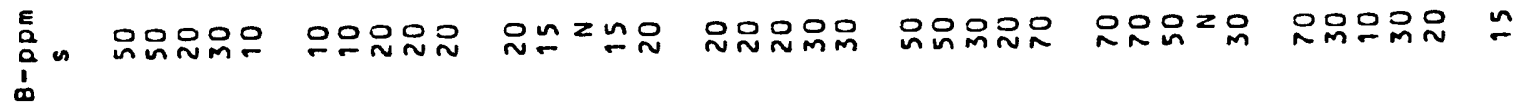

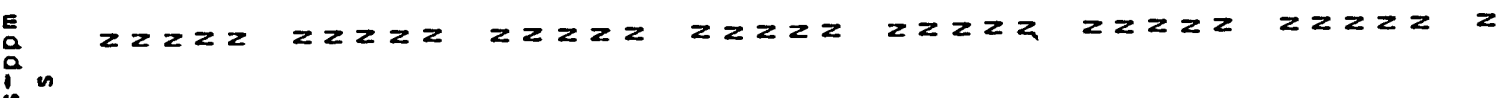

E

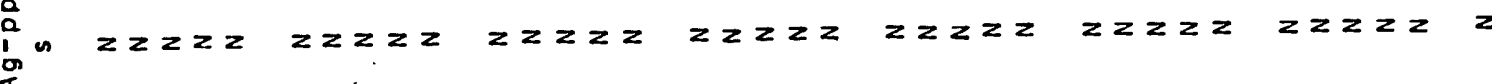

옹응ㅇㅇ음

nnok

iñ

응응응응

ํㅛㅇ

$\Sigma$
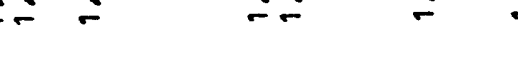

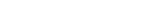

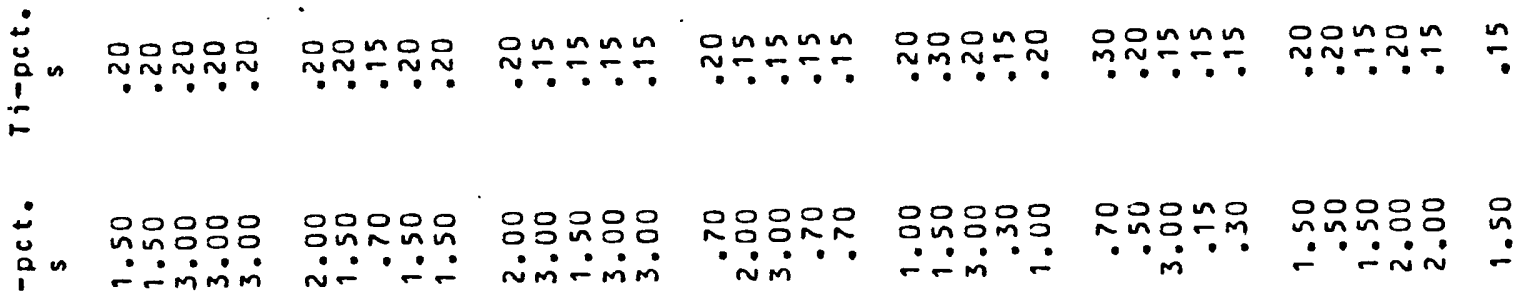

\section{?}

$\approx \sim \mathcal{N} \sim$ ํํํํํํํำำ

onasa

min 000 in ㅇํㅇํำ

nunun

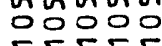

nin

잉ㅇㅇ응

กิก⿻上丨

แnnแn

응으으응

ח-7n

ษัก๊ำ

$\tilde{\sim} \sim \tilde{\sim} \sim$

acasa

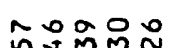

กับ品昌 的药的的

忨范的的

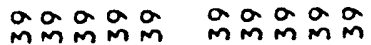

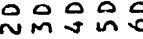

nูn nnn

으음응ㅇㅇㅇ

는

오응ㅇㅇ응 ํํํํํㅇㅇำ กิธูกัํํำ

는
우영응

กตำ

00000

는든 nับ N

$\sim \sim \infty 00$

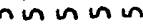

กนกทnก

으으응ㅇㅁ응

우웅ㅇํ으

ununun

oo goo

으은ㅁㅇㅇㅇ

ำกㄴำ

$=0 \operatorname{mon}$ mmmm

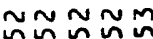

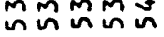

$=\frac{n}{\sim}$ กิ

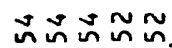

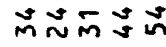

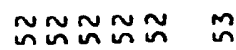

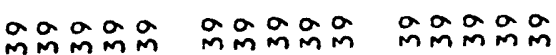

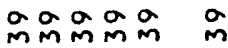

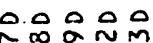

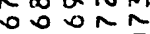
응으음 옹ㅇㅇㅇ응

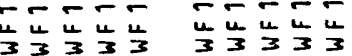

로음우우 กั0 응ㅇㅇㅇㅇㅇㅡ

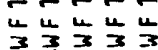

오싱ㅇㅇㅇㅇㅇ aaㅇ 음으으으믄

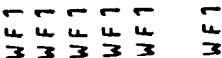


E⿱

E
a
in

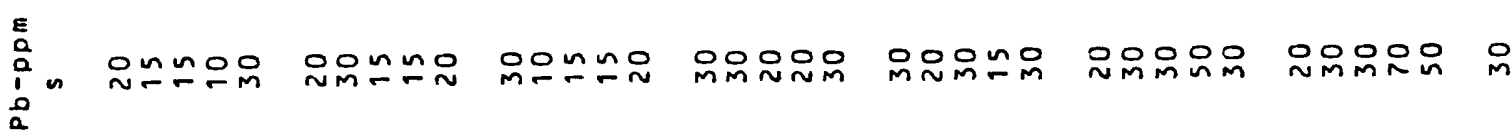

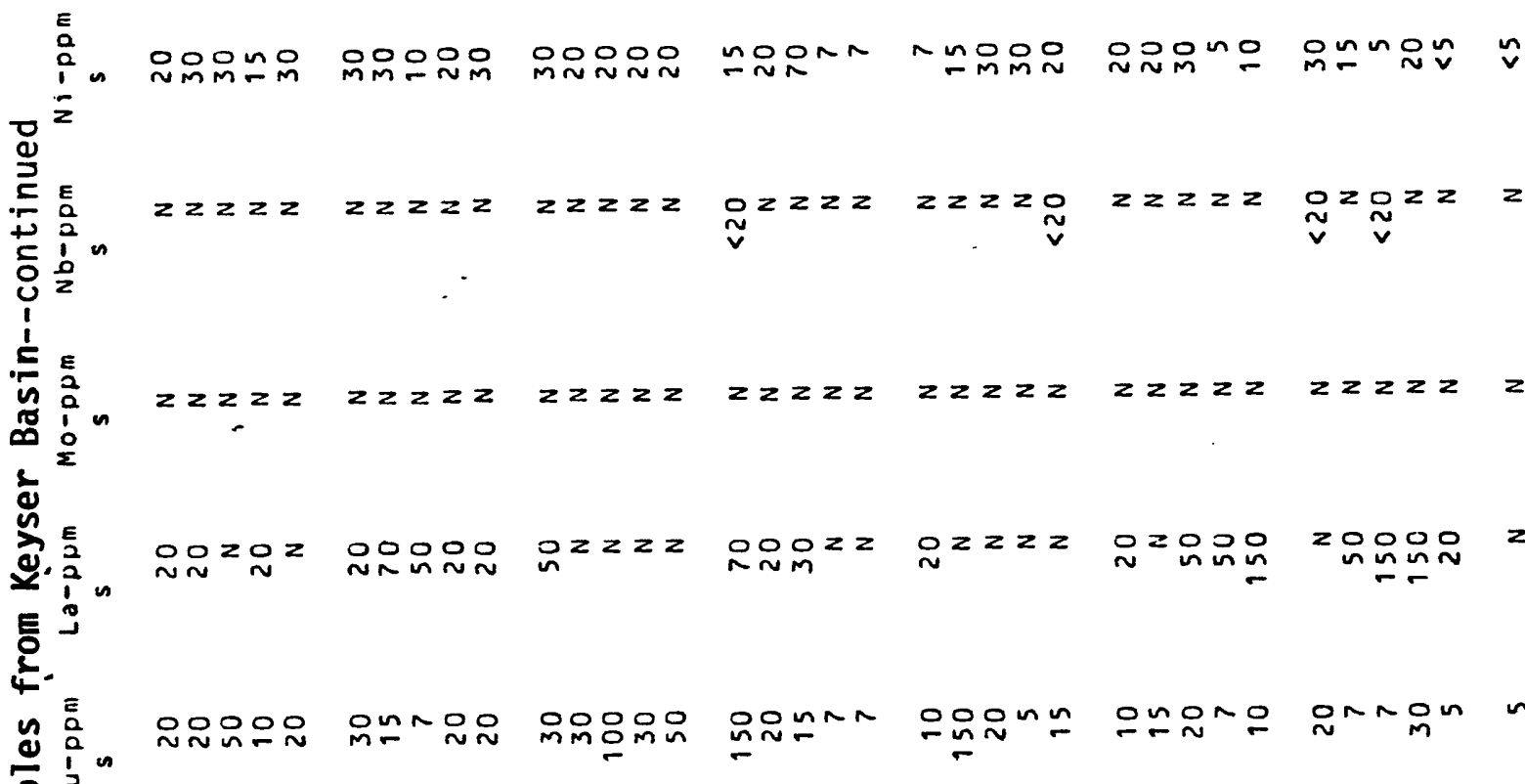

을

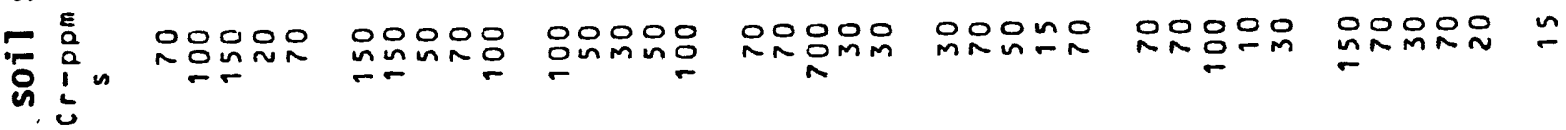

(9)

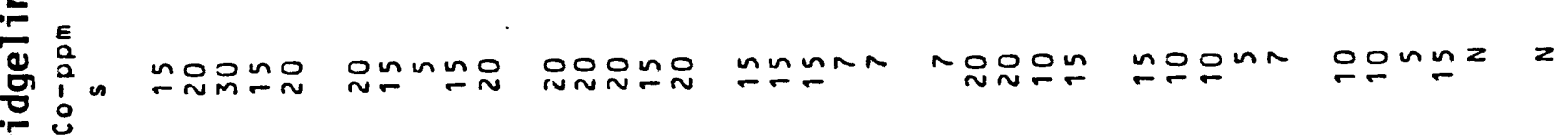
¿E

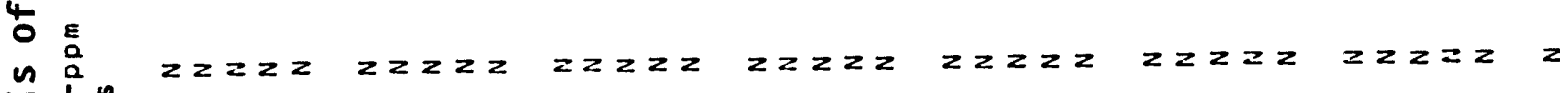

is

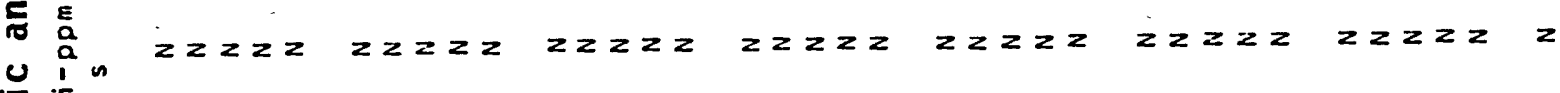

$\therefore \therefore$

作

응.

$\frac{E}{2}$

$z z z z$

$z z z z$

$z z z z 2 z z z z$

$z z z z$

$z \geq z z 2$

ڤ

은의응

nิmnnn

O00000

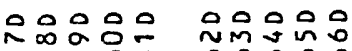

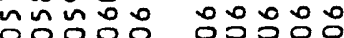

0음

응ㅇㅇㅇํ

$\div=54$

4.

는는

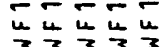

는요용

ñก̃

응ㅇㅇ음

는

응ㅇㅇ으웅 응

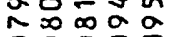

0000잉

$\div \div \div \div$

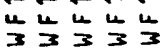

응오옹으응

a a a a o

0000

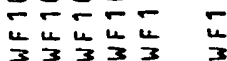

$r$ 


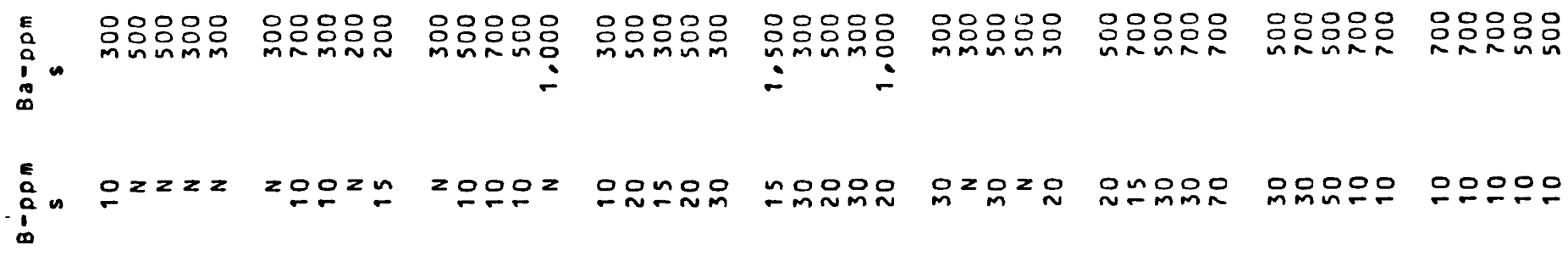

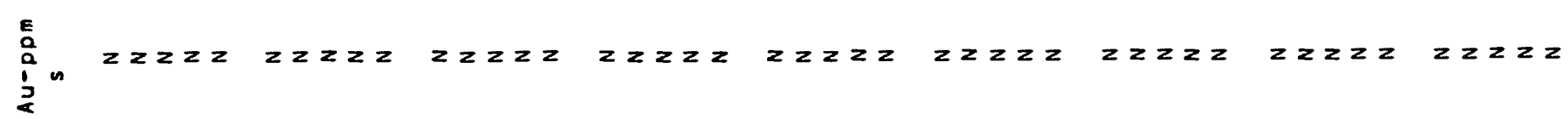
:

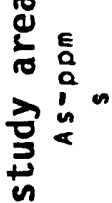

范 :

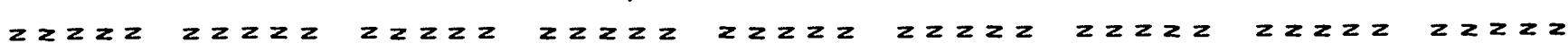

동

동

这

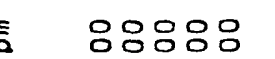

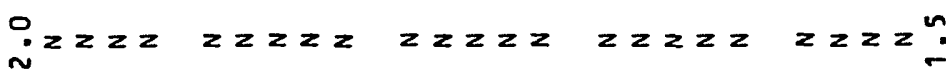

$z \geq z \geq z$

$z z z z$

$z z z z$

22222

응ㅇㅇㅇ응ㅇㅇㅇㅇㅇ응 minn

음임요

옹ㅇㅇㅇㅇㅇㅇㅇㅡ

응음응응ㅇㅁㅇㅇㅁㅇ

응음음응음

$\because$

옹음음음

수은

응응응음

n?ำ

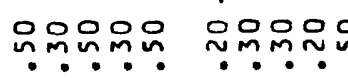

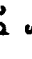

웅음욤요

윰온유뭉

욱우웅

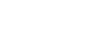

(n)

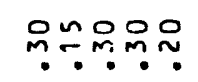

옦으뭉ㅇ

운ำㅇํำ

움우우

E:

y

玄

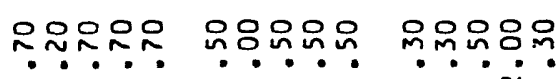

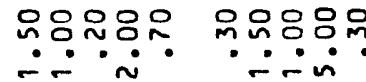

옴유운모.

응잉유운은

$\therefore \dot{\sim}$

m...

$\therefore$

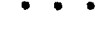

인우수숭

음으늠음

is

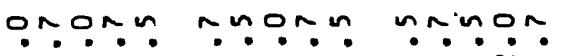

$\ddot{\sim} \because \dot{m}:$

$\because 0 \because \because \because$

om:on?

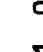

$\because \because \because 00$

n n m no

noon m a)

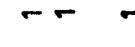

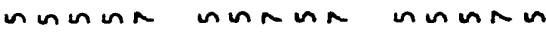

$n \operatorname{mnn} n$

$n \sim n n$

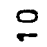

$\sim \sim N$

\section{r}

$\sim \sim r n$

$\sim \sim m n$

$\sim \sim n \sim n$

04

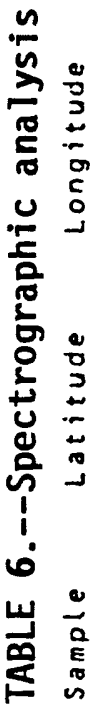

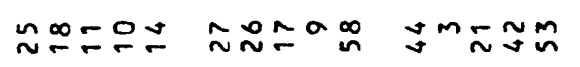

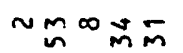

กักับำก

जo에네

$\infty$

nnm nn

n $n$ ก

ก $0 \infty \infty$

n

in $\infty \sim n$

nn n m n

nn m n m

nnm nn

nnnm

nn m n m

$\sim \infty \infty \infty \infty$

으은으은

음은

으응ㅇㅇ응

음으음음

이은

ตับณ์ณ์

ina

nunun

作

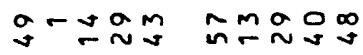

ำกํำ

Gññ

ํํำปกั

gก๊ำก

누요

율ㄷㄴ

เก $\sim \simeq$

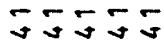

i. 250

$005=5$

- 555

$-5-50$

a a o

a a a a

a a o a

a 0 a

a m $\begin{aligned} & \alpha \\ & \text { m }\end{aligned}$

a a a

a o a o

MON

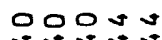

a a o

a

N a d a n o $90 \%$ m

- 웅ㅇㅇ

웅ㅇㅇㅇㅣ

동동응응

는

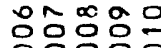

00000

는ㅎㄴ

응ㅇㅇㅇㅜ

$=\simeq m \div n$

드으응

t5:5is

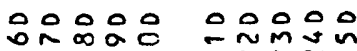

응ㅇㅇㅇㅇㅇ

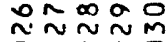

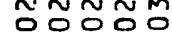

등둥

은음ㅇㄷㄷ

은든

$\begin{array}{llll}5 & \frac{1}{3} & \frac{1}{3} & \frac{1}{3} \\ 3 & 3 & 3\end{array}$

음ㅇㅇㅇㅇ음

ตNMmM

móñón

은든

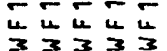

응ㅇㅇㅇㅛ 소용 लू́̆

든

ᄂ)

응ㅇㅇㅇ 응ํㅇำ

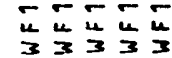


๓onon ronn

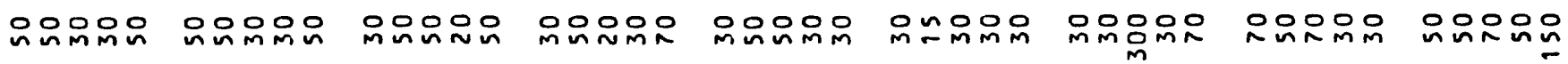

d

0

ㅇํㄱ:

ind $n$

음ำn nnoom

$\sin \frac{\pi}{2}$

$\sin 2 \sin$

$\pi R$

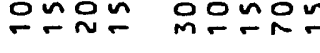

nno음

웃은 는윰

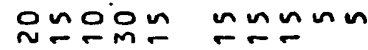

4 E

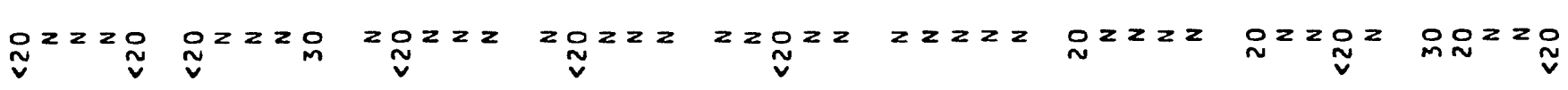

동

5 in

E

$z z 2 z z \quad z w z z$

$2 z 2 z 2 \quad 2 z 2 \tilde{v}$

$z z z z n$

$z z z z \quad z 2 N z z$

$\approx z z 0 z \quad z z z 20$

웅ㅇㅇㅇㅇㅇ

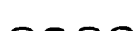

은ำ

은은은

은옹응응

엉ㅇㅇㅇㅇ

잉ㅇㅇㅇ

z은응 은운요

온응으음

응응은응

통

$\stackrel{\text { U }}{\circ} \mathrm{a}$

음

onoom oOmno

응응ㅇ 으능은

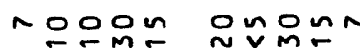

ro은

음은

noogo

nNFTn

둥.

0000000000

00000 00000

no 000

00000 co000

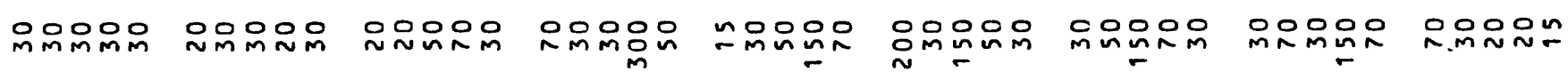

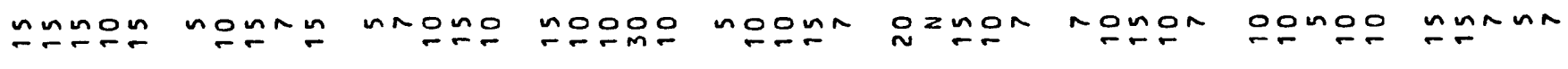

4

旾采 ris

20

U

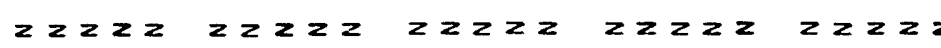

$z z z 2 z \quad z 2 z z 2$

$z z z 2 z \quad 2 z 2 z$

$z \geq z z$

$z z z z$

$z z z z$

$z z z z$

$z z 2 z$

$z z z z 2 z z 2 z$

$2 z 2 z 2 \quad 2 z 2 z 2$

\&ั

i

- 0 웅ㅇㅇ

ํํำำ

응읃옹응옹

든

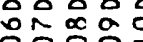

음읃응응 ㅡㄴ

든

- ํํ요

둥ㄷㅎㄷㅡ

$-5=-5$

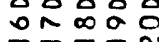

등등

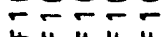

- 200

$\sim \approx \sim \sim \sim ⿻ 上$

c00ㅇㅇㅇ

둔

숭ㅇㅇ

กักับ

응응ㅇㅇㅇ

응ㅇㅇㅇ음

mกิmm

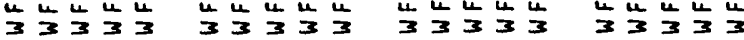

는은

$3 \div 3 \frac{1}{3} 3$

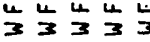

웅용ㅇㅇ minmm

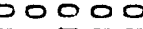
는 $\frac{1}{3} \div 3$

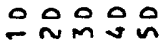

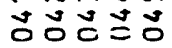

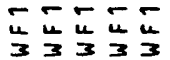




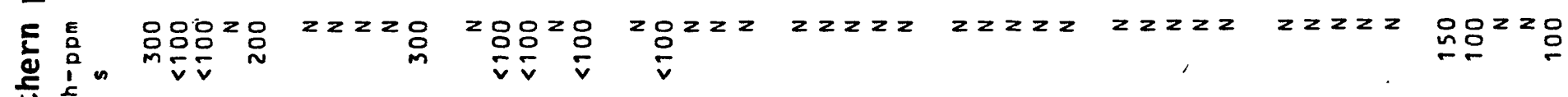
,

in

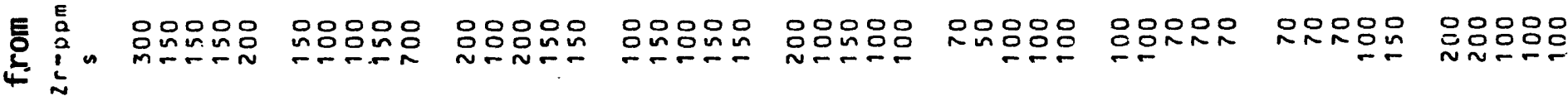

y

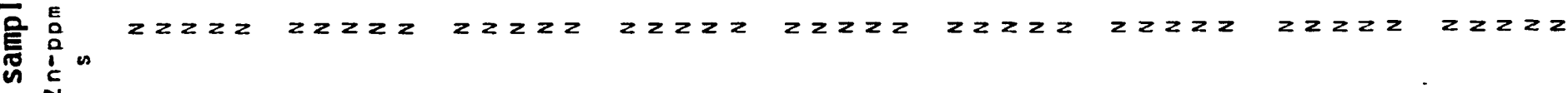

:

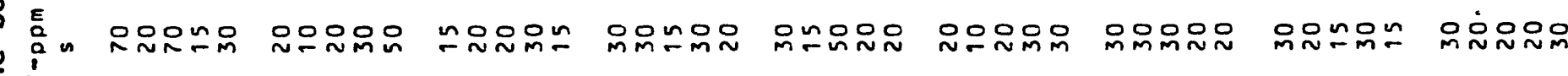
崖

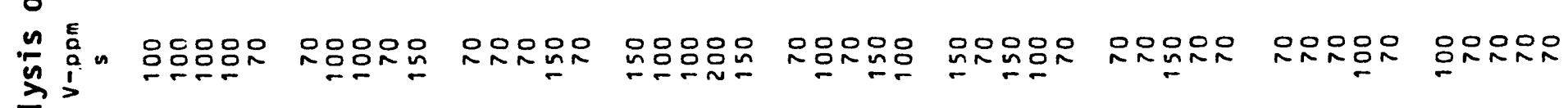

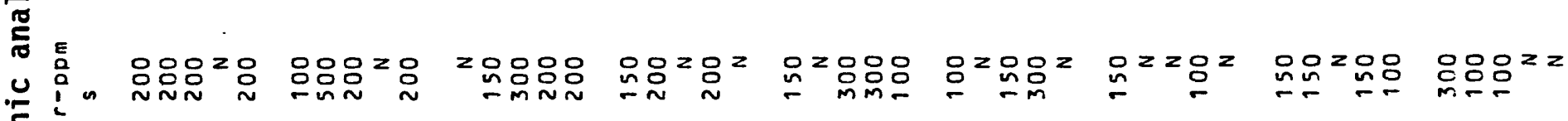

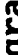

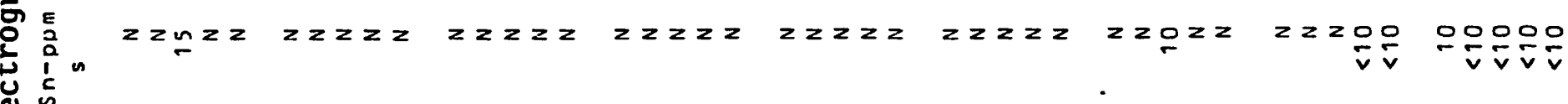

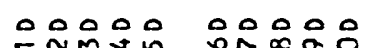

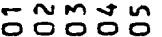
응응ㅇㅇㅇㅇ

든 ำ

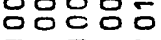

둔다

옹ㅇㅇㅇ 드응

- --5

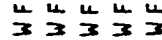

웅ㅇㅇ응

동ำ

등ㄷㅇㅇㅣ

은우우응

กักำ

믕ㅁㅇㅇㅁㅇ

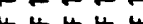

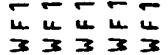

옹ㅇㅇㅇ กิกับ 음음ㅇㅁㅇ

$4 \frac{4}{3} \frac{5}{3}$

00000 minmm oㅇoㅇㅇ

응웅ㅇㅇ응 minmming 응ㅇㅇㅇㅇㅇ

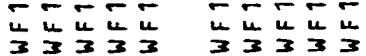

응ㅇㅇㅇㅛ 可㑸式 ---ra

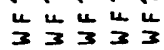




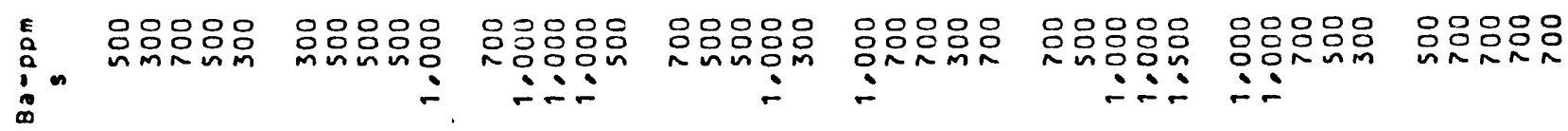

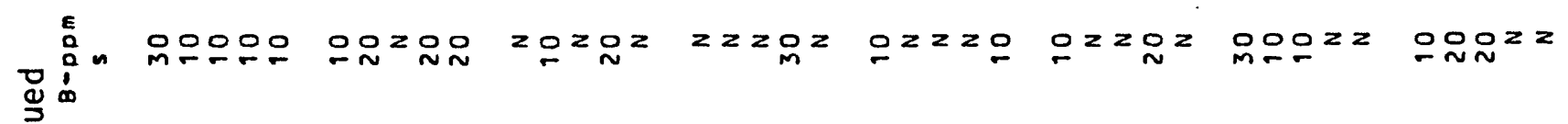


4. 5

$+\frac{1}{2}$ 


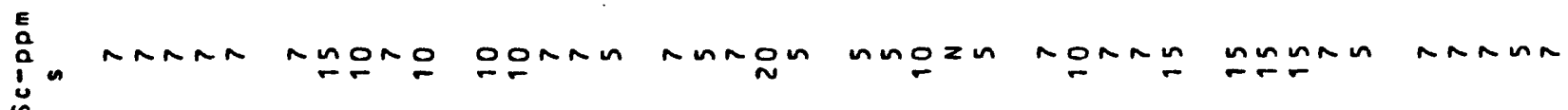

㗊

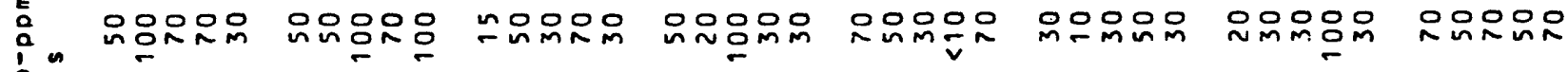

으응

함<smiles>CCCCCCCCCCCCC</smiles>

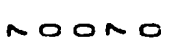

nun

우은

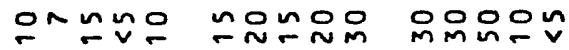

กำะㅇำ

4

동

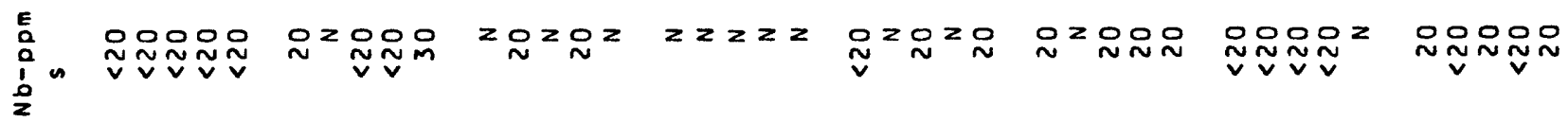

옹

王

웅

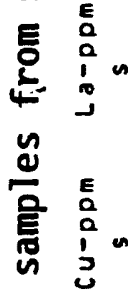

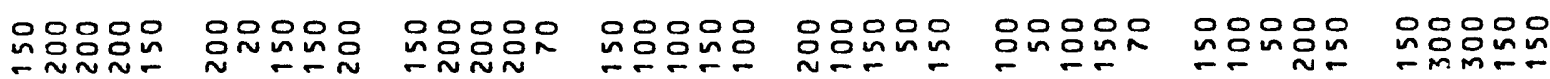

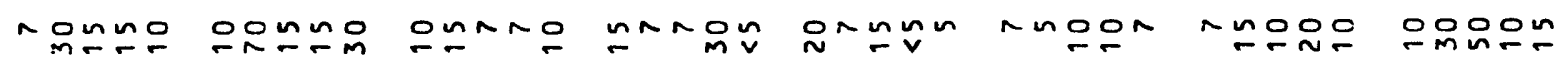

ro

\&

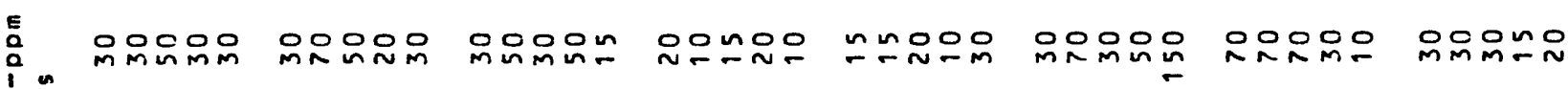

$=0$

is

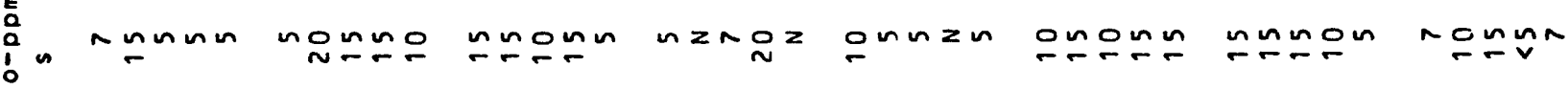

4

ㅇ

(1)

E $z z z z z \quad z z z z \quad z z z z \quad z z z z \quad z z z z \quad z z z z \quad z z z z \quad z z z z$ in

$2 \geq 2 z$

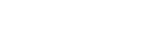
2

.

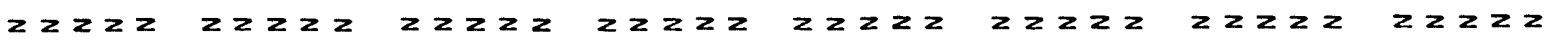
$\ddot{\infty}$

$z 2 z z$

$z 2 z z 2$

$z z 2 z z$

$z \geq z$

$z z z z z$ zzz

$z z z z z$

$z \geq z z 2$

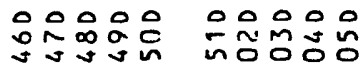

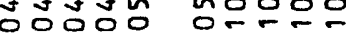

단단한

$\stackrel{4}{3} \div 3$

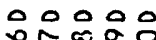

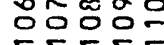

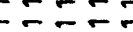

는

응으영ㅇ 웃옹ㅇㅇ

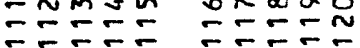

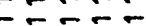

Еニテこ

는 $\frac{1}{3}=$

응요영

$\sim \sim \sim \sim N$

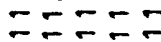

는

$5-5-5$

는

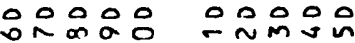

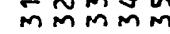

- $=5$

흔ㅎㄴ

3333 


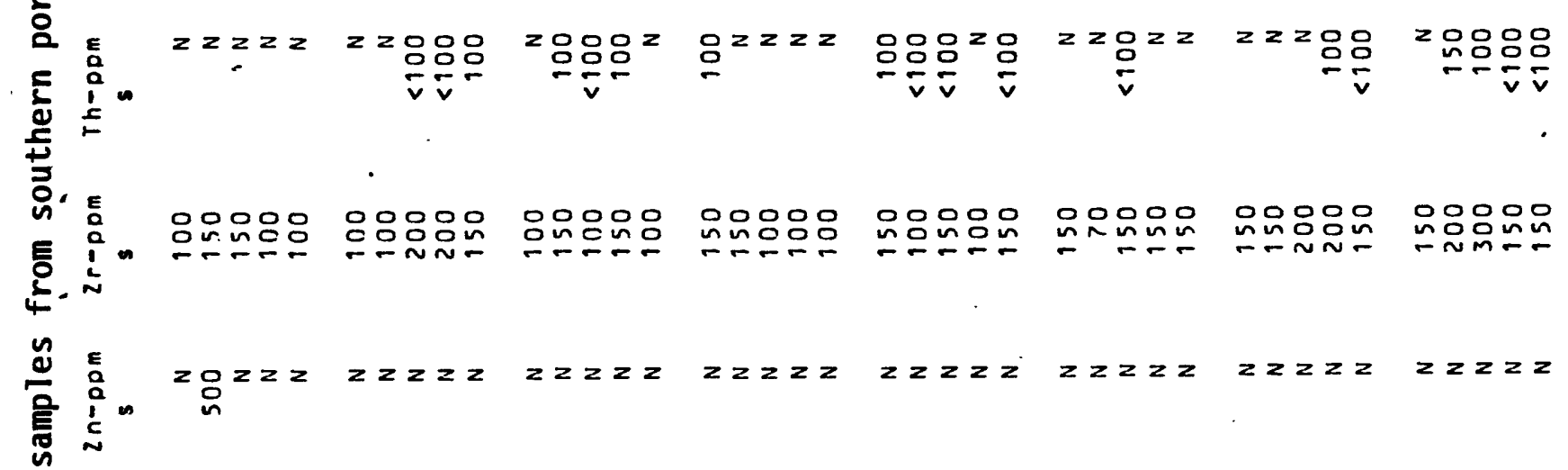

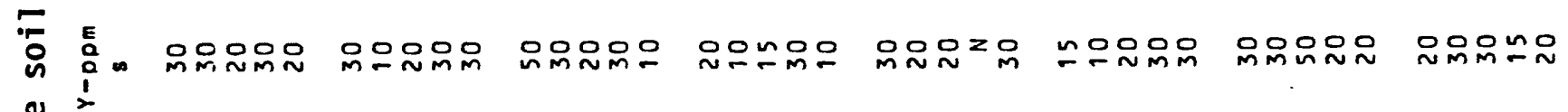
:

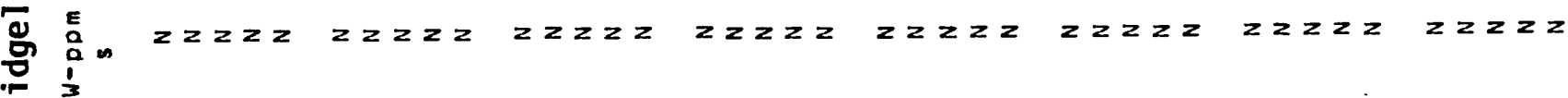

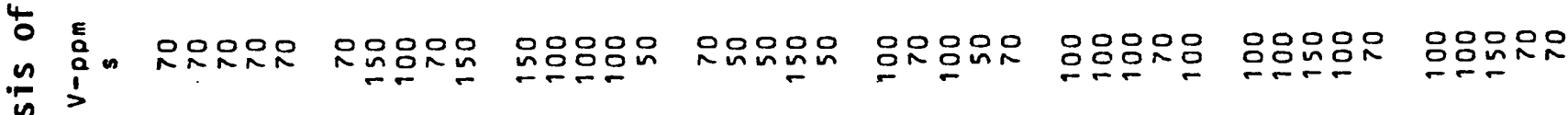

言 $z z z g z$ z

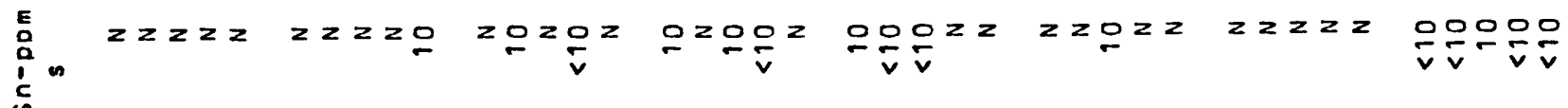

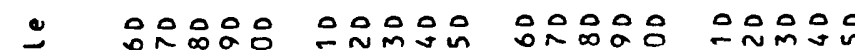

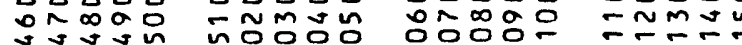

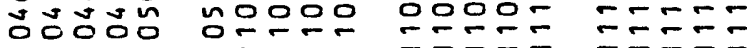
й

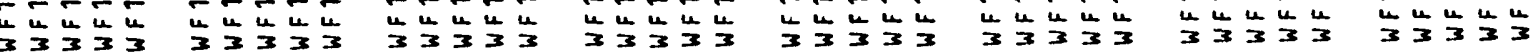

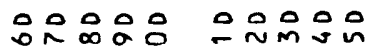

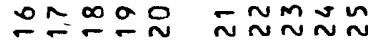

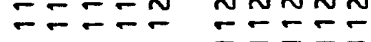
$-5-5-5-5$

$\therefore 0000 \quad 00000$

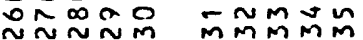
-arar

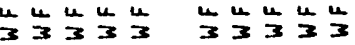




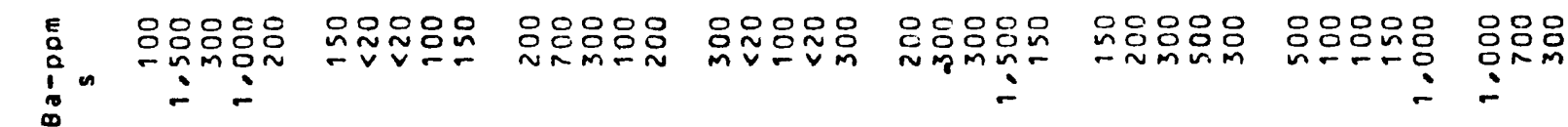

(2)

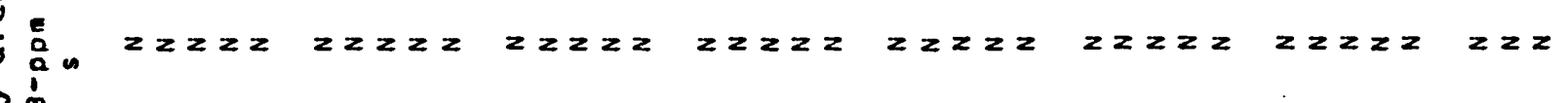

ఫु

吾

동

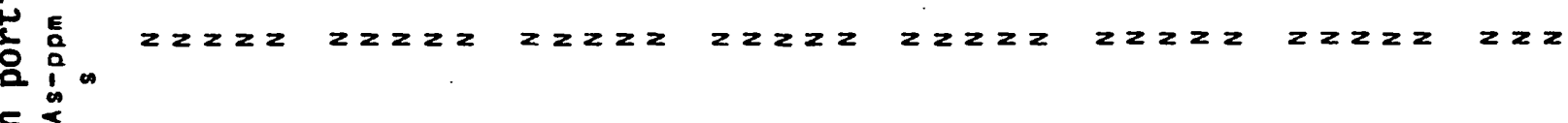

E

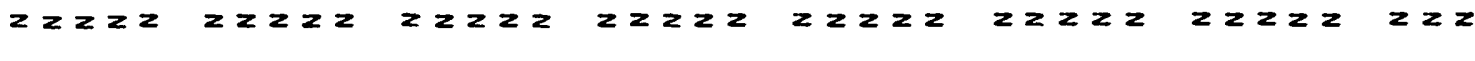

-

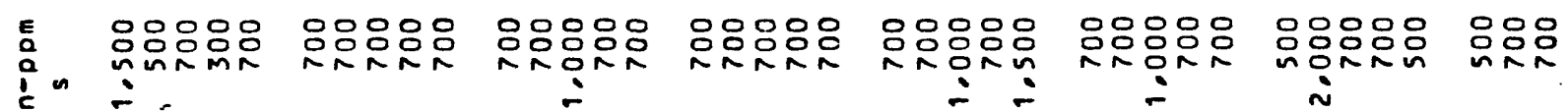
$\therefore$

每

onn N

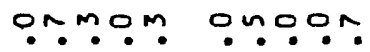

onmuno unmoo

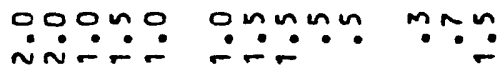

운

iั

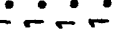

$\because \because \dot{\sim}$

$\because \because \sim \sim$

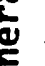

i

nnn

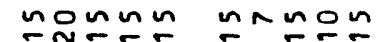

$\because \longleftarrow D_{N}$

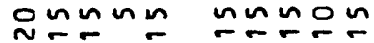

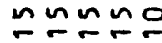

$\sim \varkappa n$

o $0 \mathrm{~m}$ m

room mun

Numñ mNumn omñn

0.0.0. 0.000. 0.000. 90000

nmunn

ㅁํํำ.

InNANO OON

(1)

$\because 0 m \div$

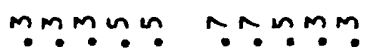

nmmon

$\because ヘ \backsim \backsim$ ก

กษกด

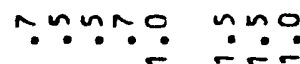

4

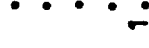

-

- $\cdot$ -

$n$

$r$

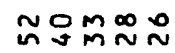

nnnนn

ทีททที

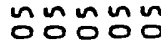

웅ㅇㅇㅇㅇㅇ은

กับง

- gNan

○กตำ

oingoin

오ำํำ

은

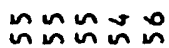

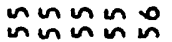

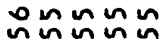

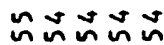

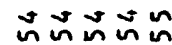

nunun nun nun

nunun

nunun

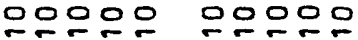

응ㅇㅇㅇㅇㅇ응

응ㅇㅇㅇㅇㅇ

nnunn

으웅ㅇㅇㅇㅇㅇㅇ

오웅요요

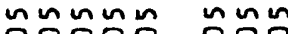

응ㅇㅇ응 웅으

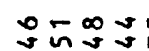

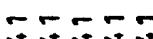

$\stackrel{\infty}{\sim} \backsim n n$

nomua

응우웅

n $\sim \mathcal{n}$

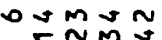

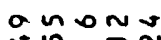

TE $=09$

ommm岛

TNTE:

araog

arasa

a a a a

a $a \circ a$

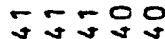

araa

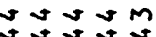

ara

mmas

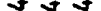

in m

MMmm

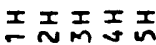

ธํํㅇำ

ニニ

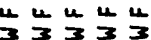

IIIII IIIII

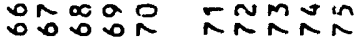
으느는도 - $-2 \pi$ 는 3

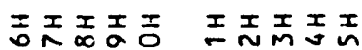
소숫 든 든든

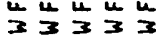

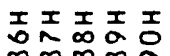
$\infty \infty \infty \infty 0$ 프 uั

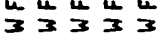

IIIII I III aaga a 듣 프

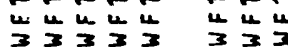

$\infty \infty \infty \infty$

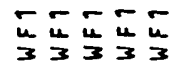

$$
\text { - } \because 9
$$




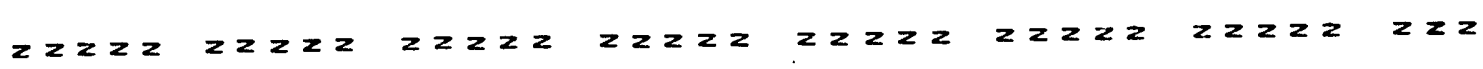

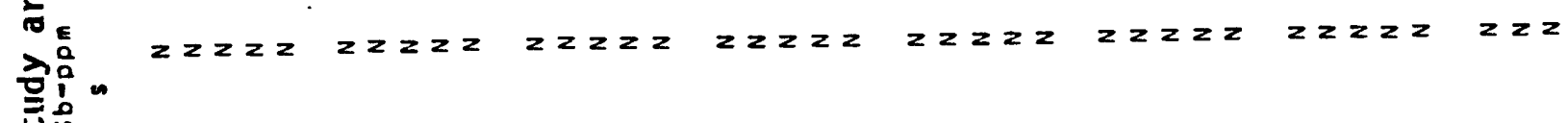

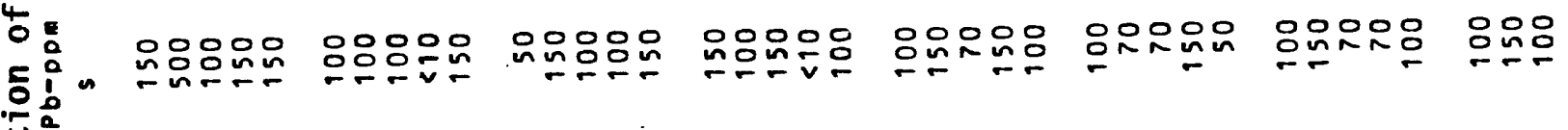
눙

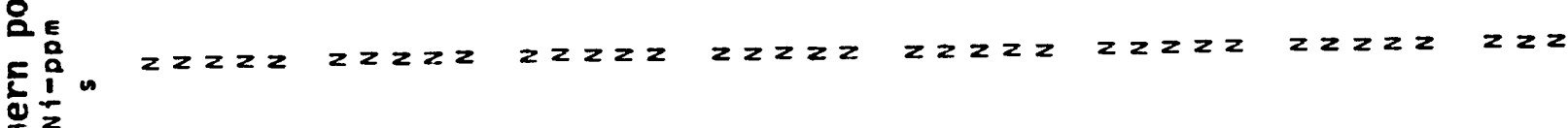
$\underline{\underline{x}}$

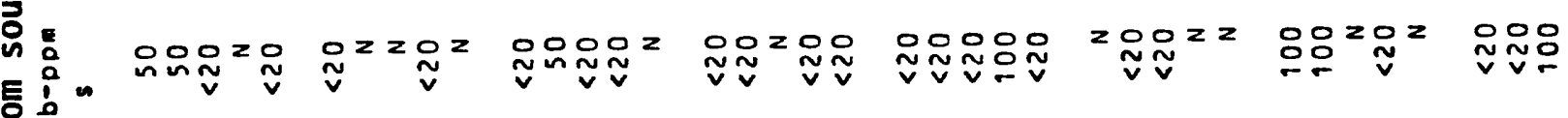

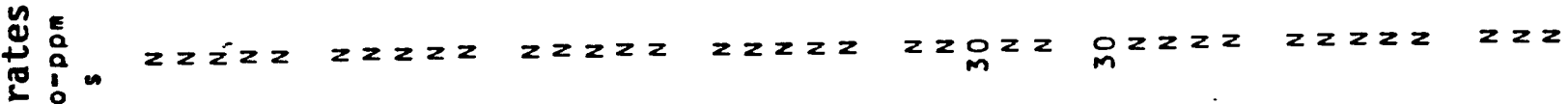

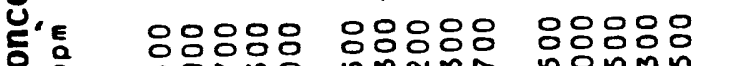

00000

웅으 웅웅응

응응응 용음 요요

ㅇำทำ

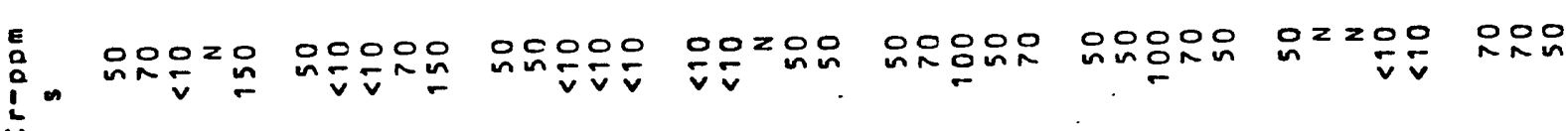

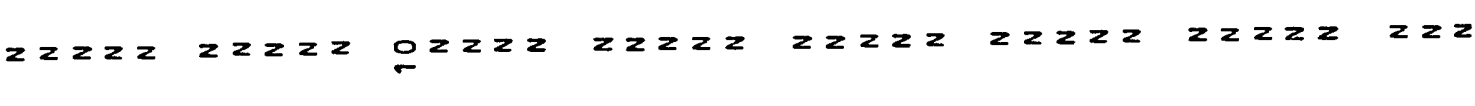

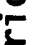
4

告 : 몬

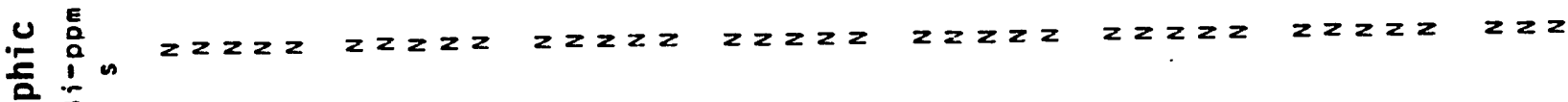

色

官

兘

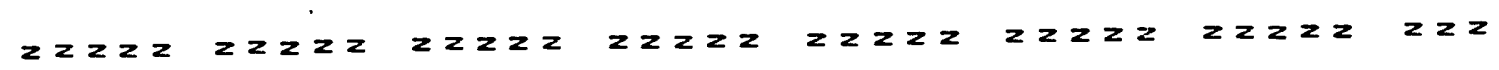
i.

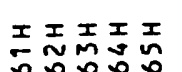

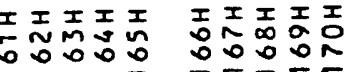

EEF士 =E5

느는 는

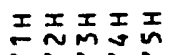

$\simeq \cong \simeq \check{N}$

든

는 แ แ แ

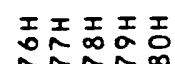

ヘNヘN舟

テーr-。

$5=5 \div$

$-\div=-5$

II工正王

$\infty \infty \infty \infty$

$\div \sigma \div \div 5$

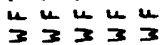

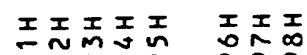
aagad aad テテ

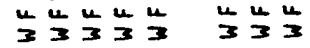




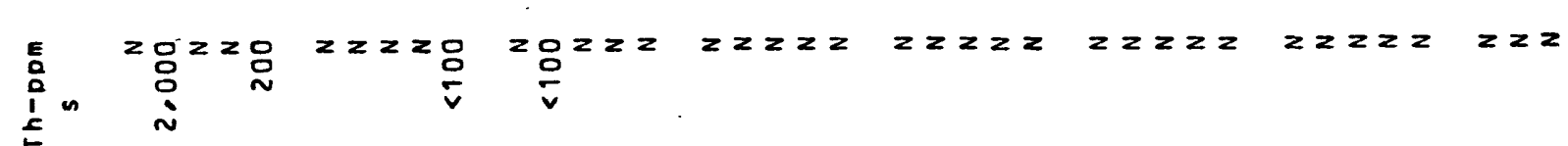

응응용응ㅇㅇㅇㅇㅇ응

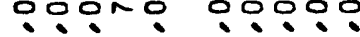

$\dot{\sim} \tilde{\wedge} \dot{\wedge} \dot{\sim} \dot{\sim} \dot{\sim} \dot{\wedge}$

응응용응

응응응음

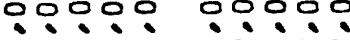

응응ㅇㅇㅇㅇㅇㅇ

응ㅇㅇㅇ음

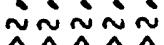

$\dot{\sim} \dot{\sim} \dot{\sim} \dot{\wedge}$

$\dot{\sim} \dot{i} \dot{i} \dot{\wedge}$

(1) n

응용응 응응

$\dot{\sim} \dot{\sim} \dot{\sim} \dot{n}$

웅ㅇㅇㅇ응

ชั้

통

$z z z z$

$z z z z$

$z z 2 z z$

$z z z z z$

$z z z z z$

$z z z z z \quad z z z z \quad z z z$

\section{읏음응음은}

는

응음ㅇㅇㅇ응

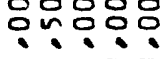

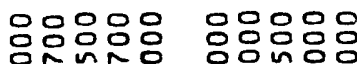

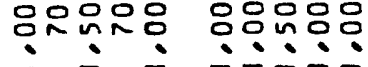

옹옹은은옹 $\because$

음웃윰ㅇㅇㅇ

읏음웅음 움웃은 $\therefore \therefore \div$

$z z z z$

$z 2 z z$

$z \geq 2 z 2$

$z z \geq z$

$z \geq \underset{0}{0} \geq 2$

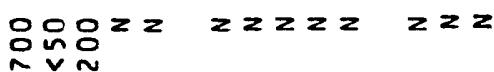

4

\section{(n)}

ñ

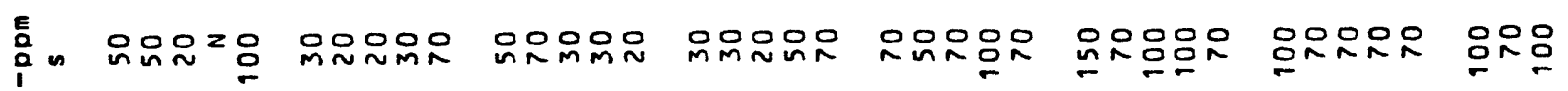

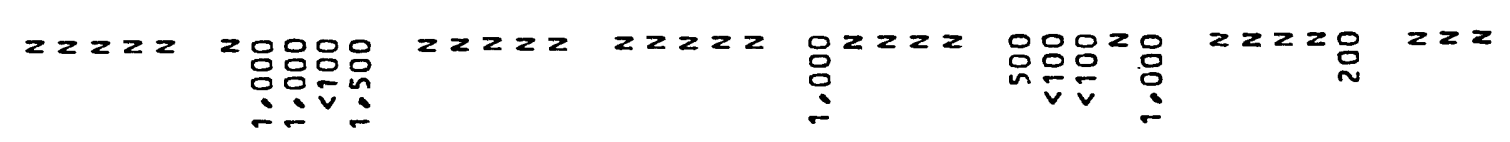

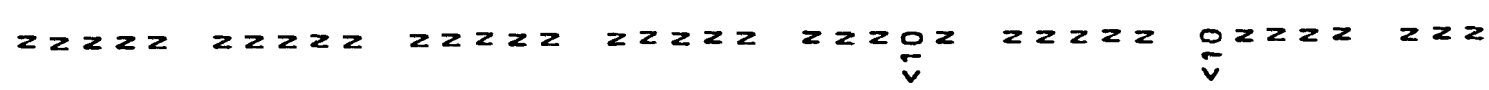

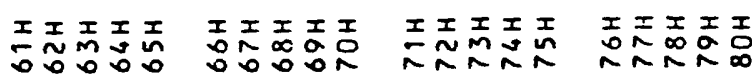

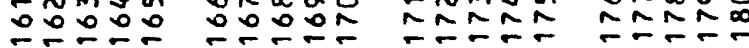

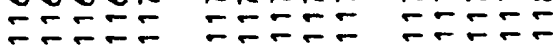

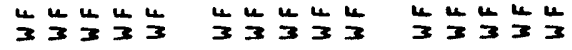

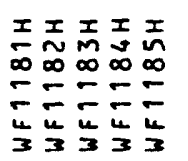

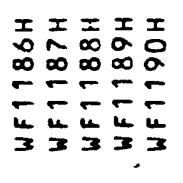

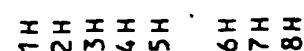
뭉aㅁ음음 든든

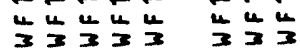

